\title{
A RESOURCE FOR THE EDWARD S. CURTIS COLLECTION AT THE ART GALLERY OF ONTARIO
}

\author{
By \\ Mary Kate Patterson \\ BFA Photography, California College of the Arts, 2007
}

\author{
A thesis \\ presented to Ryerson University \\ in partial fulfillment of the \\ requirements of the degree of \\ Master of Arts \\ In the program of
}

Film and Photographic Preservation \& Collections Management

Toronto, Ontario, Canada, 2017

CMary Kate Patterson 2017 


\section{AUTHOR'S DECLARATION FOR ELECTRONIC SUBMISSION OF A THESIS}

I hereby declare that I am the sole author of this thesis. This is a true copy of the thesis, including any required final revisions, as accepted by my examiners.

I authorize Ryerson University to lend this thesis to other institutions or individuals for the purpose of scholarly research

I further authorize Ryerson University to reproduce this thesis by photocopying or by other means, in total or in part, at the request of other institutions or individuals for the purpose of scholarly research.

I understand that my thesis may be made electronically available to the public. 


\section{Abstract}

A Resource for the Edward S. Curtis Collection at the Art Gallery of Ontario Master of Arts

2017

Mary Kate Patterson

Film and Photographic Preservation \& Collections Management

Ryerson University

This thesis intends to contextualize the Edward S. Curtis (1868-1952) material at the Art Gallery of Ontario into a resource document containing cataloguing and background information. The fully illustrated essay and document provide details of Curtis's life's work, The North American Indian (19071930). The thesis is divided into two parts: a research paper and a resource document. The first part is a research paper describing Curtis's project and the literature surrounding it and culminating in a description of the sixty-eight pieces in the AGO collection. The second part is an illustrated resource document that catalogues one object per page and includes an extended note for each object. The AGO collection of Curtis material consists of sixty-five photogravures, one cyanotype, one postcard, and one film. 


\section{Acknowledgements}

First, I would like to thank Katy Whitman and Sophie Hackett at the Art Gallery of Ontario for acting as my first and second readers and providing valuable feedback during the process of writing this thesis.

Thank you to Maia-Mari Sutnik at the Art Gallery of Ontario for sharing her knowledge of the Edward S. Curtis Collection. Also, thank you to Stephanie Burdzy for help with The Museum System.

I would also like to thank Don Snyder for being endlessly supportive of all of my thesis topics.

Thank you to Sarah Kennel and Gordon Wilkins at the Peabody Essex Museum for providing access and resources to the Edward S. Curtis collection and for inspiring this idea during my summer internship.

Thank you to my family for always encouraging me to pursue my passions.

Last but certainly not least, I would like to thank my classmates. Their friendship and support has gotten me through many frustrations. Thank you. 


\section{Table of Contents}

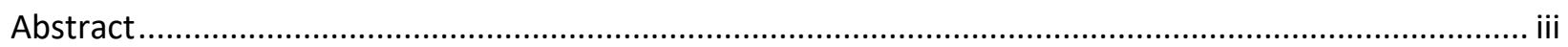

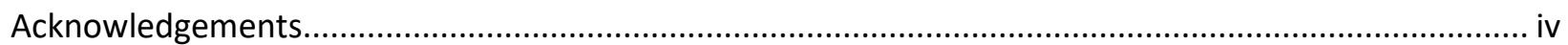

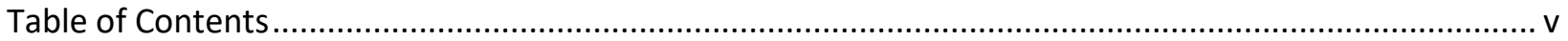

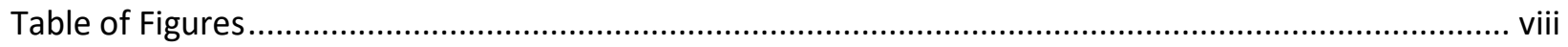

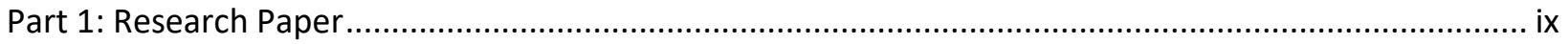

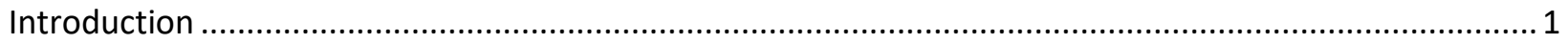

The North American Indian ............................................................................................. 3

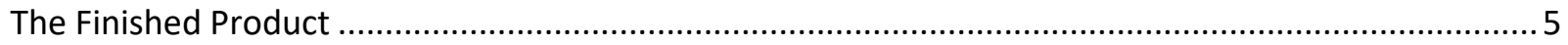

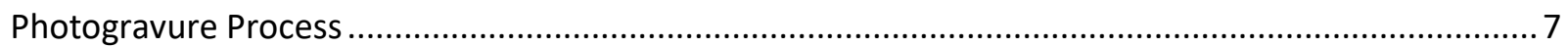

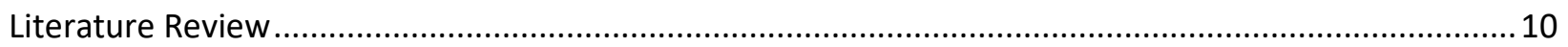

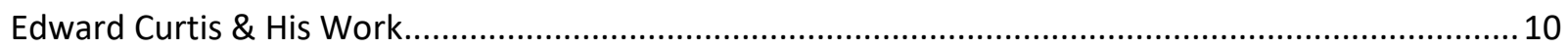

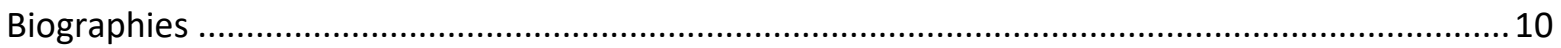

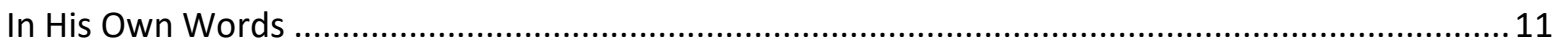

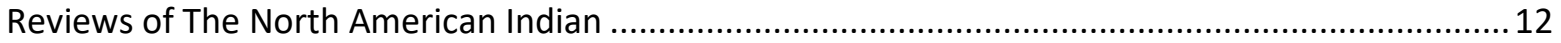

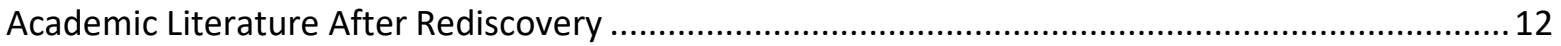

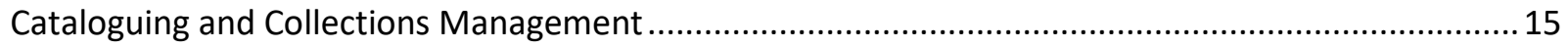

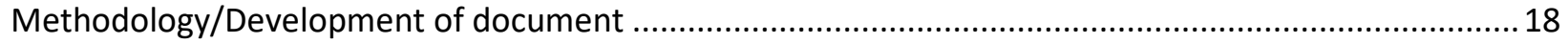

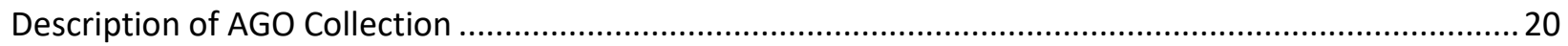

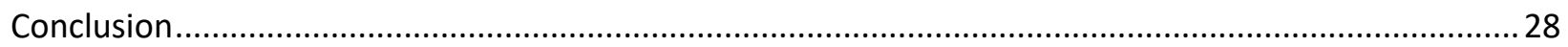

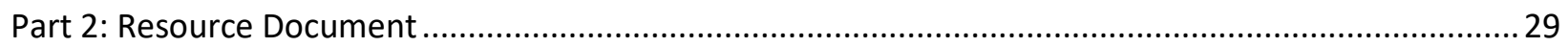


Introduction

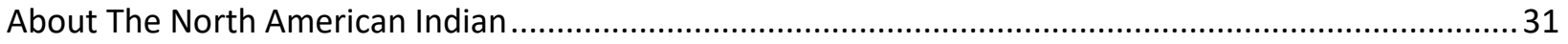

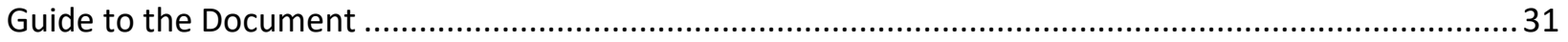

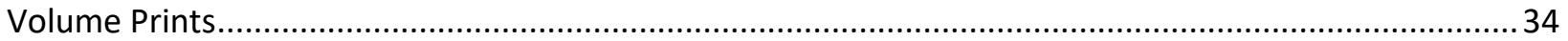

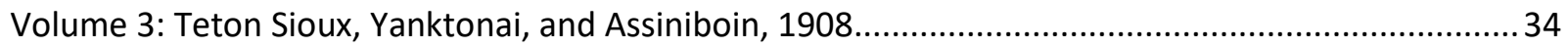

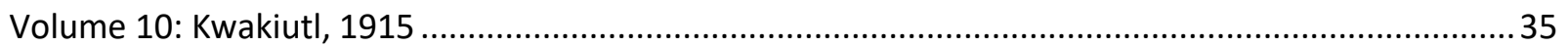

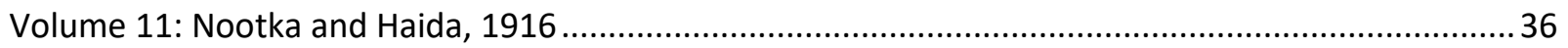



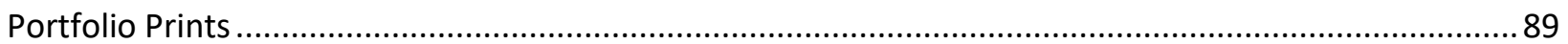

Portfolio 8: Nez Perces, Wallawalla, Umatilla, Cayuse, and Chinookan Tribes, 1911 ..........................89

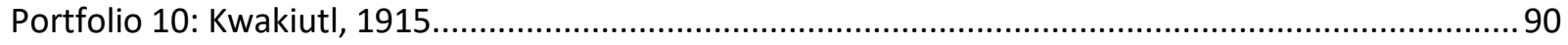

Portfolio 13: Hupa, Yurok, Karok, Wiyot, Tolowa, Tututni, Shasta, Achomawi, Klamath, 1924............91

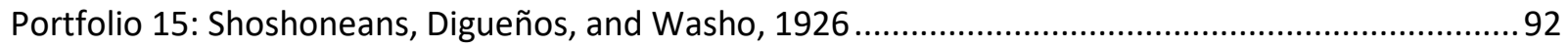

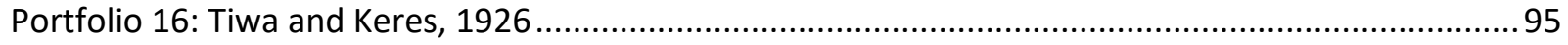

Portfolio 19: Oklahoma, Wichita, Cheyenne, Oto, Comanche, and Peyote Cult, 1930 ........................98

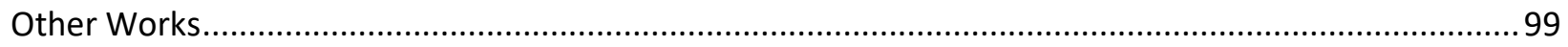

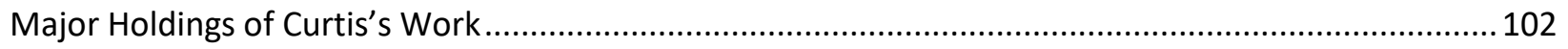

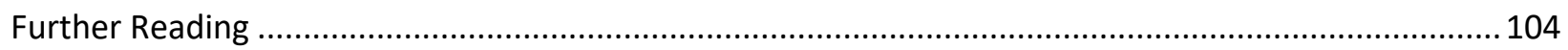

Appendix A: Volumes of The North American Indian ................................................................... 105

Appendix B: John Andrew \& Son Sample Book of Photogravures...................................................... 106 
Appendix C: Life and Career of Edward S. Curtis .

Appendix D: "Photography" by Edward S. Curtis.

Appendix E: "The Amateur Photographer" by Edward S. Curtis 117

Bibliography 125 


\section{Table of Figures}

Figure 1. Map of North American Indians as Witnessed by Edward S. Curtis ........................................

Figure 2. Close-up of Plate Number, Copyright Information, \& credits to photogravure makers .............. 7

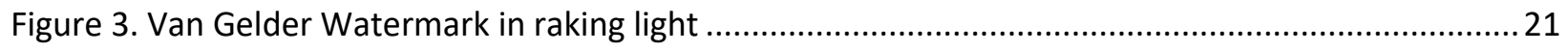

Figure 4. Close-ups in Raking Light on Three Different Etching Stocks................................................ 22

Figure 5. Locations of Boxes on Shelves in the Prints \& Drawings Vault .............................................. 24

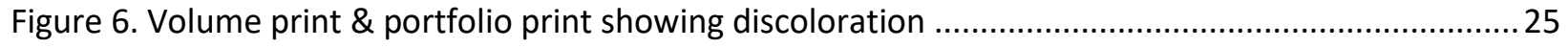

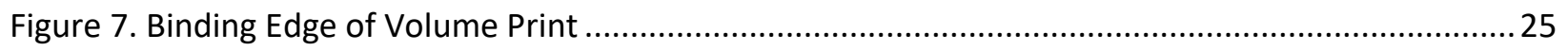


Part 1: Research Paper 


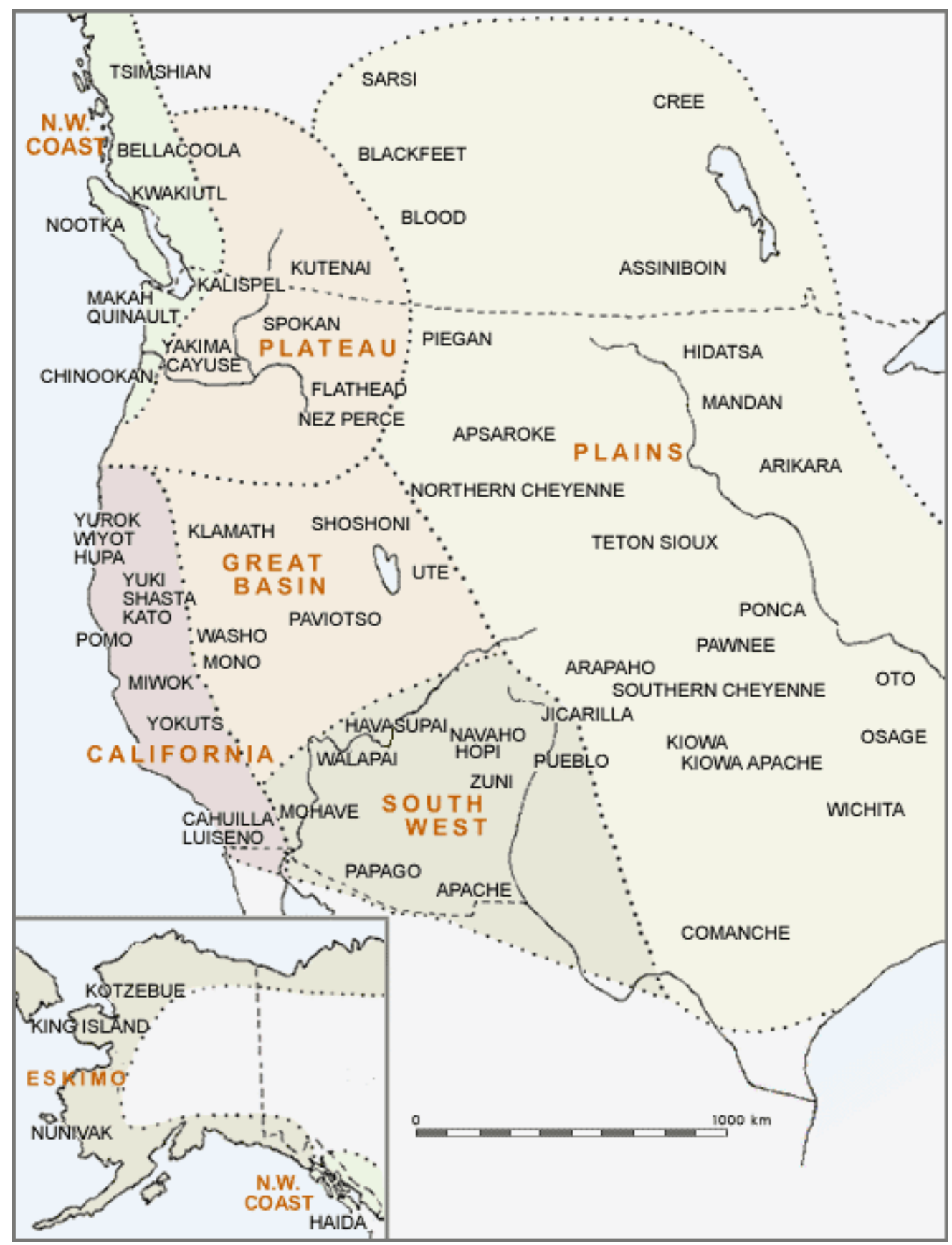

Figure 1. North American Indians as Witnessed by Edward S. Curtis. Map prepared for Edward S. Curtis's "The North American Indian:" Photographic Images. 2001. Library of Congress. http://curtis.library.northwestern.edu/map.html. Accessed August 12, 2017. Originally based on map by Mick Gidley in The Vanishing Race (1976). 


\section{Introduction}

Edward S. Curtis (1868-1952) is best known for his epic publication, The North American Indian: Being A Series of Volumes Picturing and Describing the Indians of the United States, the Dominion of Canada, and Alaska (1907-1930), an ethnographic study in twenty volumes of photographs and text. The book project took him thirty years to complete and includes more than two thousand photogravures, some used as illustrations and others included in companion portfolios. Curtis made approximately 40,000 negatives for the project in his effort to document and photograph the indigenous tribes still living west of the Mississippi River (Figure 1).

The Art Gallery of Ontario (AGO) collection of Curtis material consists of sixty-five photogravures from various volumes and portfolios of The North American Indian, a cyanotype, a postcard, and the film In the Land of the War Canoes. Most of the works come from Volume 11 of The North American Indian and were acquired by the gallery in four separate gifts. A further and more detailed explanation of the collection is located after the literature review.

The purpose of this thesis is to create a fully-illustrated document as a resource for the AGO collection of Curtis material. The completed document will provide information that contextualizes the images within Curtis's oeuvre and verify cataloguing information already in the AGO's database. The objective of the document is to furnish the AGO curatorial staff and visiting researchers with background information about the individual images in addition to providing more accessibility to the collection. Providing further information to the AGO on their Curtis images can help in future efforts to exhibit and contextualize his work within the gallery's collections.

This thesis includes an essay and a resource document. The essay includes a summary of The North American Indian project; a literature review focused on the context of production and the changing reception of Curtis's work; and a detailed description of the AGO collection of Curtis material 
establishing each work within the artist's oeuvre. The second part of this thesis project consists of a resource document. An introduction describes the content and suggests how the document should be used. Following the introduction are sixty-eight records with illustrations, cataloguing and contextual information, and an extended note for each object. The note provides context and highlights the special qualities about the object. A brief section highlights other significant collections of Curtis's work. The appendix of the thesis includes a list of all the volumes of The North American Indian and a chronology of Curtis's life and the project. 


\section{The North American Indian}

The North American Indian is a set of 20 volumes documenting 80 different tribes of the North American continent. The aim of the volumes was an ethnographic study describing the life of the indigenous peoples of North America in both images and text. In the general introduction, Curtis set out what he intended to publish: "It has been the aim to picture all features of the Indian life and environment - types of the young and the old, with their habitations, industries, ceremonies, games, and everyday customs." ${ }^{1}$ In a note to John Pierpont Morgan in an effort to secure funds for his project, Curtis went on to explain the text for the project would "treat the subject much as the pictures do, going fully into their history, life and manners, ceremony, legends and mythology...." ${ }^{2}$

Curtis sold the leather-bound volumes on a subscription basis: each volume was distributed upon completion. The first volume was published in 1907 and the final volume published in 1930. Each subscriber had the choice of three different papers for the illustrations and accompanying portfolios, the most luxurious being the most expensive. The prices ranged from $\$ 3,000$ to $\$ 3,850$ per set based on the quality of the papers, approximately $\$ 75,000$ per set at today's value. Such luxurious volumes were only available to institutions and the very wealthy. Many prominent families bought a set, including the royal family of England. J.P. Morgan financed the operation and was given twenty-five copies for his library or to distribute as he pleased. ${ }^{3}$

Curtis originally estimated that the books would take him five years to complete with J.P.

Morgan contributing $\$ 75,000$ to the project, the sum equal to twenty-five complete sets. That was $\$ 15,000$ a year, nearly $\$ 400,000$ in today's currency, to pay for all the fieldwork and the salaries of his

\footnotetext{
${ }^{1}$ Edward S. Curtis, "General Introduction," The North American Indian: Being A Series of Volumes Picturing and Describing the Indians of the United States, the Dominion of Canada, and Alaska, vol. 1, The Apache. The Jicarillas. The Navaho., (Cambridge, MA: University Press, 1907), xiii.

${ }^{2}$ Edward S. Curtis, Outline of the North American Indian Project, printed in Mick Gidley, Edward S. Curtis and the North American Indian, Incorporated (Cambridge: Cambridge University Press, 1998), 44.

${ }^{3}$ Gidley, North American Indian, Incorporated, 40.
} 
research assistants. The subscriptions would pay for the hard costs of publishing the volumes which Curtis would have to sell himself while he worked for free. Morgan ended up advancing Curtis even more money, some in the form of personal loans, coming to the amount of $\$ 60,000$. After Morgan's death, the project continued to be funded by Morgan's estate.

To accomplish his monumental task, Curtis hired assistants and took on fund-raising projects. As Curtis worked in the field, his darkroom assistant, Adolph Muhr, made photographic prints to Curtis's specifications. Curtis would develop his glass plate negatives and make cyanotypes, a contact process that produces blue-colored prints, in the field. Because of the ease of this process, Curtis could easily make notes and send them back to Muhr in Seattle. At the studio, Curtis would sell postcards, platinum prints, and "Curt-tones" ${ }^{4}$ to help fund the project. In an effort to raise additional funds for the project, Curtis made the film In the Land of the Head Hunters (1914). The film was the first to use a cast comprised entirely of Native Americans and is the oldest surviving film made in Canada. Due to the distributor suddenly declaring bankruptcy, the film was never distributed and became a commercial failure. In 1974, Bill Holm and George Quimby restored the film, renaming it In the Land of the War Canoes.

Of the planned print run of 500 sets, only 272 sets were made in Curtis's lifetime, with additional sets printed later in the 1970 s by Charles Lauriat, a Boston bookseller who acquired the plates and unsold books from the Morgan Library in $1935 .{ }^{5}$ It is almost impossible to tell how many complete volumes or sets have survived because many of the sets were unbound so that the photogravures could

\footnotetext{
4 "Curt-tone," also known as orotone and goldtone, is a photographic process where a positive photograph on glass is backed with a mixture of bronzing powders and varnish giving the photograph a gold color. Curtis pioneered the process.

${ }^{5}$ Timothy Egan, Short Nights of the Shadow Catcher: The Epic Life and Immortal Photographs of Edward S. Curtis (New York: Houghton Mifflin Harcourt, 2012), 317.
} 
be sold separately during the revival of interest in Curtis during the 1970s. Many of the existing full sets belong to university libraries and rare book collections.

Curtis self-published The North American Indian; however, the books do include credits to two different presses. These presses bound and printed the actual books. The University Press in Boston, a precursor of the Harvard University Press, bound the first five volumes between 1907 and 1909. In 1911, the Plimpton Press printed the sixth volume. The logo of the Plimpton Press for Volumes 6 through 8 include the initials of William Dana Orcutt, a well-known book designer at the time. Prior to 1910, Orcutt worked at the University Press. ${ }^{6}$ Based on this information, it is probable that Orcutt was the book designer of The North American Indian. Made by master bookbinders and engravers, the books became works of art in and of themselves.

\section{The Finished Product}

The volumes and portfolios of The North American Indian contain 2,226 photogravure plates in total, of which 723 are separate portfolio prints, enclosed in folded leather folios. Each volume contains approximately 75 prints. The spines of each volume are gold stamped with line decoration, the sets title, author, volume number in roman numerals, the tribes that were the subject of each volume, and publication date. Each volume features one or more related tribes from a geographical region, ranging from the Plains to the Southwest, Northwest, and Alaska. Chapters describe customs, folklore, and general history. Transcribed songs appear every so often in the text. The appendix of each volume includes "tribal summaries" which list language, population, dress, dwellings, primitive foods, arts and industries, games, political and social organization, marriage, ceremonies, mortuary customs, war, and religious practices. Smaller tribes or villages that fall under the umbrella term for the tribes are listed.

\footnotetext{
${ }^{6}$ Wikipedia, s.v. "William Dana Orcutt," last modified April 15, 2017, https://en.wikipedia.org/wiki/William_Dana _Orcutt.
} 
Comparative vocabularies are also recorded. In some volumes, biographical information is written about the subjects of the portraits.

The photogravures in the volumes occur on unnumbered pages every two to four pages and illustrate the volume. As illustrations, they do not relate directly to the text on the facing page but provide scenes of the sites and people being discussed within the entire volume. The portfolios usually contain thirty-five prints to complement each volume. Volumes 1,8 , and 20 contain thirty-nine, thirtysix, and thirty-four prints, respectively. The plates are numbered consecutively up to 722 . There are two plates numbered 400. Each portfolio includes a sheet of captions entitled "List of Large Plates Supplementing Volume...." Curtis and his staff chose the most artistic of images to be reproduced as portfolio prints. ${ }^{7}$ Curtis called them the "more important pictures." ${ }^{8}$ The portfolio prints were seen as the best, the most interesting, the prime examples of what Curtis had created. Many of these prints are portraits and romantic portrayals of people in natural settings. In contrast, the volume prints can be repetitive or banal. None of the images from the volumes are repeated in the portfolios and vice versa.

Each portfolio print has the plate number listed on the upper left. All the photogravures, regardless of size, have the title listed at the bottom left, Curtis's copyright information centered below the image, and credit to the maker of the photogravure on the bottom right (Figure 2). The printer of the photogravures is also credited in the list of illustrations at the beginning of each volume. The printer for Volumes 1 through 11 was John Andrew \& Son in Boston, MA and Suffolk Engraving Co. in Cambridge, MA printed Volumes 12 through 20. According to a sample book from 1913, John Andrew \&

\footnotetext{
${ }^{7}$ The North American Indian in the Northwestern University McCormick Library of Special Collections - A Description, Northwestern University Digital Library Collections, http://curtis.library.northwestern.edu/description .html.

${ }^{8}$ Curtis, Outline of the North American Indian Project, printed in Gidley, North American Indian, Incorporated, 44.
} 
Son is a department of Suffolk Engraving \& Electrotyping Co. ${ }^{9}$ Six years passed between the publishing of Volume 11 and Volume 12.
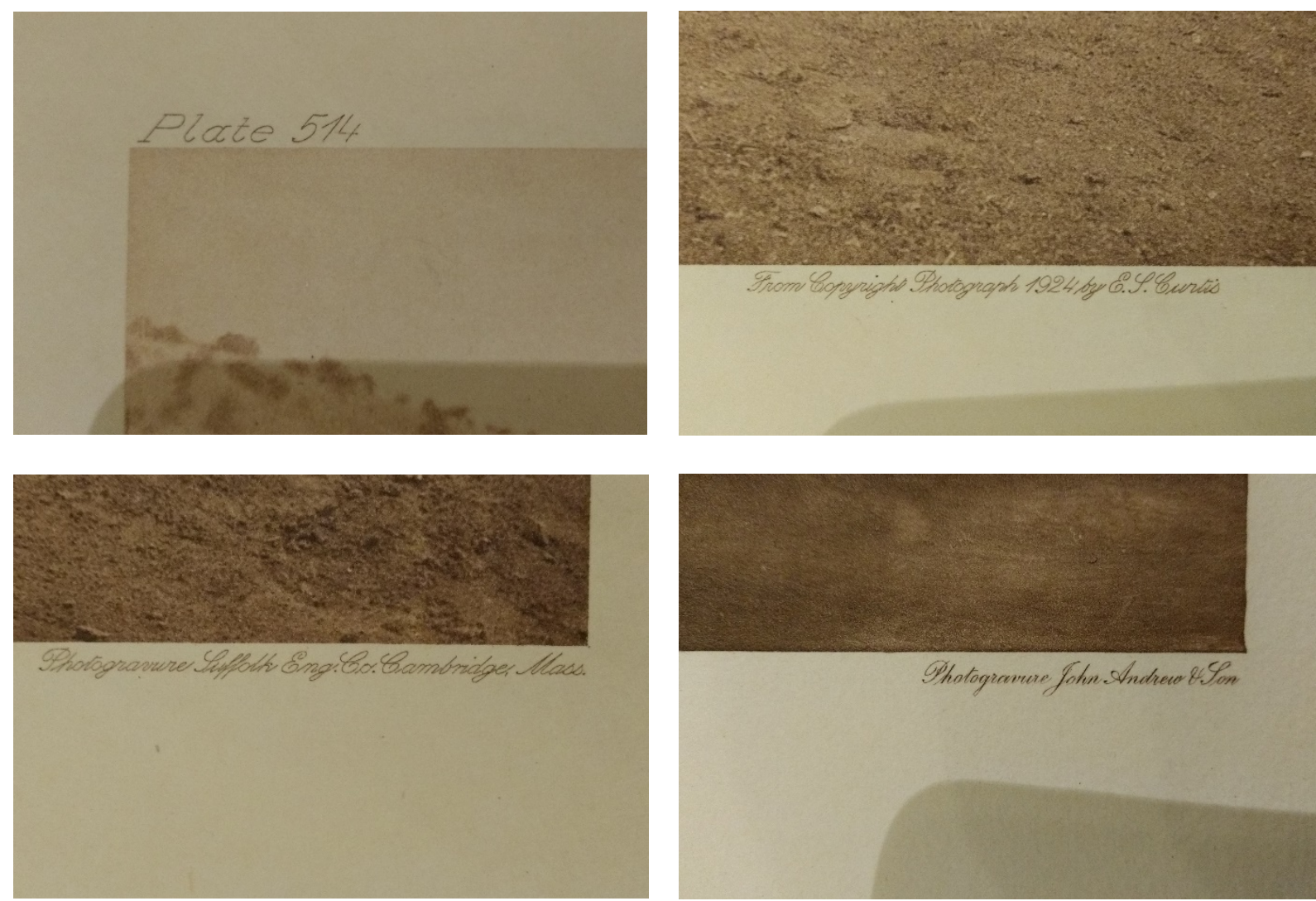

Figure 2. Top left: Close-up of Plate Number, Top right: Close-up of Copyright Information, Bottom left \& right: Close-ups of credit to photogravure maker. Photographs by author.

\section{Photogravure Process}

Photogravure, also referred to as gravure or photoengraving, is a photomechanical process, meaning that the photographic image is produced from ink on paper, as opposed to a photochemical process that produces an image from the reaction between silver and light. Curtis gave his name to his photography studio under which he stated his vocation as "Photographer and Photoengraver," but by the time The North American Indian started publishing, he gave up the practice of photoengraving and

\footnotetext{
${ }^{9}$ John Andrew \& Son sample book of photogravures, David A. Hanson Collection of the History of Photomechanical Reproduction, Sterling and Francine Clark Art Institute Library, http://maca.contentdm.oclc.org /cdm/ref/collection/p1325coll1/id/3743.
} 
relied on a specialized company to produce the photogravures. From 1880 into the twentieth century, printers and publishers used the photogravure process for book illustration, and art photographers used it as a print medium. ${ }^{10}$ This process adapted intaglio printing, a method of printing where the ink is held in low areas of the plate, ${ }^{11}$ and aquatint, a method of using a resist to create tonal gradations, ${ }^{12}$ with the photographic image to produce a highly-refined print. Photogravure combines both a photographic practice with traditional intaglio printing methods to form stable, reproducible photographic images.

The Clark Art Institute Library in Williamstown, MA holds a sample book printed in 1913 from John Andrew \& Son, a department of the Suffolk Engraving \& Electrotyping Company. ${ }^{13}$ The sample book presents several examples, including some from Curtis, "to call attention to the superiority of this process to any in existence at the present day for the reproducing of pictorial or commercial subjects." On the next few pages, they explain their photogravure process, which I have reproduced in the appendix of the resource and summarized here:

To a polished copper plate, a fine resin powder is applied resulting in what is referred to as a fine grain. Sensitized gelatin is applied over the grain in the same method used at the time for photographic gelatin dry plates. A positive photograph of the same size as the desired print is made on glass and contact printed on the copper plate. Exposure to light hardens the gelatin creating a resist for the acid that etches the plate. Where there are highlights in the photograph, the gelatin hardens preventing the acid from biting into the copper plate. The opposite happens in the dark areas of the photograph. In gray areas, the resist creates a smooth gradation. After the acid bath achieves a

\footnotetext{
${ }^{10}$ Mary Lynn Ritzenthaler, and Diane Vogt-O'Connor, Photographs: Archival Care and Management (Chicago: Society of American Archivists, 2006), 51.

${ }^{11}$ Richard Benson, The Printed Picture (New York: Museum of Modern Art, 2008), 26.

12 Ibid., 27, 40.

13 John Andrew \& Son sample book of photogravures, David A. Hanson Collection of the History of Photomechanical Reproduction, Sterling and Francine Clark Art Institute Library, http://maca.contentdm.oclc.org /cdm/ref/collection/p1325coll1/id/3743.
} 
sufficient bite, the gelatin is washed away and the plate is ready to be inked and printed. At this stage, any defects in the plate can be corrected with engraving or etching tools. The printer applies enough ink to fill the etched grains of the plate. The excess ink is wiped away with a cloth and then by hand. Dampened paper is applied to the plate and then rolled through a press. The pressure of the roller pushes the fibers of the paper into the grain. When the print is pulled from the plate, the result is a gradated photographic image made from ink. ${ }^{14}$

14 Ibid. 


\section{Literature Review}

This literature review is divided into two sections: the first discusses Edward Curtis and his work and the second discusses documents about cataloguing and collections management. The literature written about Curtis and The North American Indian is vast, so I chose to focus on books written at different points both before and after the resurgence of popularity of the work. This section follows a short discussion of biographies and a discussion of articles written by Curtis. To end, sources consulted for the creation of a resource document for the AGO are examined.

\section{Edward Curtis \& His Work}

\section{Biographies}

Many biographies of Curtis refer to him as the "Shadow Catcher," a name allegedly given to him by the Native Americans that he photographed for his life's work. Authors continue to expand upon Curtis's life story since the 1970s. Co-written by Victor Boesen and Curtis's daughter, Florence Curtis Graybill, Edward Sheriff Curtis: Visions of a Vanishing Race (1976) marks the first significant biographical account of his life, embellished by Florence's remembrances from her childhood and experiences traveling with her father. Boesen and Graybill devoted half the book to biography, supplementing Florence's memories with Curtis's personal correspondence, and half to reproducing images from The North American Indian. Barbara Davis's Edward S. Curtis: The Life and Times of a Shadow Catcher (1985) is the most cited biography in other academic works. Davis added many details to Curtis's life story, such as his strained-relationship with his brother and the collaboration of darkroom technician, Adolph Muhr. Shadow Catcher: The Life and Work of Edward S. Curtis (1994) by children's author, Laurie Lawlor, is more simplistic and functions as a thorough introduction to the man and his work. Not strictly a children's book, it would nonetheless be easily read by adults and children alike. The most recent biography, Timothy Egan's Short Nights of the Shadow Catcher: The Epic Life and Immortal Photographs of Edward Curtis (2012), brings together much of the academic work on Curtis completing a thorough 
biography of him. Egan, a Seattle-based journalist, writes for a general audience creating a dramatic story of much of the information relayed by academics. All the biographies adopt some of Curtis's romantic notions about Native Americans and the vanishing race, and exclude a critical dialogue about his methods, aesthetics, or contributions to the field of ethnography. Both Davis and Egan acknowledge some of these issues but fail to make any critical argument.

\section{In His Own Words}

Many of the academic works cite a series of articles Curtis wrote in Western Trail (1899-1900). The Seattle-based magazine published four articles by Curtis: the first on his perspective of the medium, simply titled, "Photography," (1900) and a series of three articles offering advice called "The Amateur Photographer" (1900). ${ }^{15}$ The first article contains little of Curtis's original thoughts consisting instead of two long quotations from George B. Sperry's speech at the National Photographic Convention and Edward W. Newcomb's "Diseased Photography." The three "Amateur Photographer" articles give more perspective into Curtis's approach and thoughts on making photographs, or as he liked to say "pictures." One powerful piece of advice appears in his last article printed in May 1900: "Let everyone's work show individuality. Try to make it pronounced enough that a friend could pick up one of your pictures anywhere and know it was yours." ${ }^{16} \mathrm{He}$ also advises amateurs to make a specialization of one subject in their pursuit of the perfect picture. ${ }^{17}$ One can see the achievement of both showing individuality and making a specialization of a subject in The North American Indian.

\footnotetext{
${ }^{15}$ For full transcription of Curtis's articles, see Appendices D and E.

${ }^{16}$ Edward S. Curtis, "The Amateur Photographer," Western Trail (May 1900): 468.

${ }^{17}$ Edward S. Curtis, "The Amateur Photographer," Western Trail (February 1900): 272.
} 


\section{Reviews of The North American Indian}

In correspondence with Harriet Leitch in 1948, Curtis describes how he saw more than two hundred reviews of The North American Indian and he "never saw one which voiced adverse criticism." 18 Given the exclusivity of the volumes, the steep price made them available only to the wealthy or public libraries, one wonders how many of those reviewers actually laid eyes on a volume.

Published in 1907, critic Sadakichi Hartmann wrote an article entitled, "E.S. Curtis, Photo Historian," about the forthcoming first volume of The North American Indian. Hartmann writes of the rumoured luxuriousness of the volumes before moving on to his opinion of how the camera can capture the life of Native Americans. Hartmann talks about how photography will capture the life of Native Americans more accurately and provide a valuable record for posterity, but "a painter is apt to let his imagination run away with him." ${ }^{19}$ Even though he calls Curtis the photographer of Native American peoples, Hartmann believes that the aesthetic of the images could be improved upon because the ones he had seen were a "trifle muddy." ${ }^{20}$ Hartmann clearly thought of The North American Indian as an achievement of ethnography and documentation more than artistry.

\section{Academic Literature After Rediscovery}

Since the rediscovery of Curtis in the 1970s, academic studies of his work have concentrated on the making and production of The North American Indian and the critical issues of Curtis's romanticism, the "noble savage," and the "vanishing race." For purpose of this literature review, four works stand out: Christopher Lyman's The Vanishing Race and Other Illusions: Photographs of Indians by Edward S. Curtis (1982); Mick Gidley's Edward S. Curtis and The North American Indian, Incorporated (1998);

\footnotetext{
${ }^{18}$ Curtis to Harriet Leitch, 24 November 1948, Edward S. Curtis Digital Collection, Seattle Public Library, http://cdm16118.contentdm.oclc.org/cdm/fullbrowser/collection/p16118coll16/id/108/rv/singleitem. ${ }^{19}$ Sadakichi Hartmann, Valiant Knights of Daguerre: Selected Essays on Photography and Profiles of Photographic Pioneers (Berkeley: University of California Press, 1978), 270.

${ }^{20}$ Ibid., 271.
} 
Shamoon Zamir's The Gift of the Face: Portraiture and Time in Edward S. Curtis's The North American Indian (2014); and Christopher Cardozo's One Hundred Masterworks (2015). These four books present Curtis and his work from different perspectives according to the time in which they were published and the relative amount of research available or undertaken.

Published to accompany a Smithsonian Institution exhibition of Curtis photographs, The Vanishing Race and Other Illusions became one of the first books to look critically at The North American Indian. The re-emergence of Curtis's work coincided with a resurgence in activism for Native American rights which called into question of Curtis's intentions and attitudes and what his images, in fact, portrayed, namely the ideas of the "vanishing race" and "noble savage." The centrality of these two ideas in The North American Indian is, for Lyman, what cements Curtis's racism and ethnocentrism. Lyman charges Curtis with using inaccurate costuming and the Pictorialist aesthetic to romanticize the "noble savage." Bill Holm, a Curtis scholar, rebuts the charge of inaccurate costuming in a review of The Vanishing Race finding that only a single shirt repeatedly appears in sixteen photographs. ${ }^{21}$ In his first and only publication, Lyman defined the narrative about Curtis's work for years to come. An overall negative look, The Vanishing Race condemns Curtis for his Pictorialist approach in his images and his recreations of costumes and events. These criticisms continue to follow Curtis's images, impinging on any discussions of their cultural value and reducing his work to nothing more than a white man's exploitation of oppressed peoples. In my research, I have seen Lyman's arguments used without citation as though they are facts.

Mick Gidley's first major publication, Edward S. Curtis and the North American Indian, Incorporated, came in 1998 after twenty years of research. He published his first article about Curtis in 1978, and North American Indian, Incorporated marked his sixth publication. Though he started

\footnotetext{
${ }^{21}$ Bill Holm, review of The Vanishing Race and Other Illusions: Photographs of Indians by Edward S. Curtis, by Christopher M. Lyman, American Indian Art Magazine 8, no. 3 (1983): 70.
} 
publishing before Lyman, Gidley's first articles were relatively minor and only published in scholarly journals, unlike Lyman's book that accompanied a major exhibition. By 1998, the activism of the 1960s and 1970s had tapered off but exhibitions of Curtis's work continued to be popular and the work more valuable financially. Gidley remarks in one of his essays that Lyman's only major accomplishment is linking Curtis to Pictorialism. ${ }^{22}$ Lyman thoroughly discusses the history of photography through the Pictorialist Movement drawing comparisons between Curtis's approach and Alfred Stieglitz, one of the founding members of the Photo-Secession and a major supporter of art photography. While Lyman does not directly state that Curtis was involved in the movement, the influence of it can be seen in Curtis's use of textured papers, soft focus, and chiaroscuro. These techniques together with Lyman's inclusion of this history allows the reader to draw the conclusion that Curtis was a Pictorialist.

The major difference between The Vanishing Race and Other Illusions and Gidley's North American Indian, Incorporated is the tone that the authors use to describe Curtis and his photographs. Lyman's overall tone is one of condemnation while Gidley takes an even-handed approach. Gidley takes a critical look and refrains from making judgements. He also provides transcripts of original documents that he looked at when conducting his research. This gives the reader the opportunity to make their own judgements about Curtis.

Shamoon Zamir's The Gift of the Face presents an emerging point of view on Curtis's work, which is the level of agency and participation the subjects had in the making of the photographs. The main argument of The Gift of the Face is the subjects of Curtis's images, especially the portraits, were active participants in the taking of their photographs and, therefore, the images could be considered self-portraits. ${ }^{23}$ This idea goes against the popular belief that Curtis was merely taking advantage of the

\footnotetext{
${ }^{22}$ Mick Gidley, "Edward S. Curtis Goes to the Mountain," Pacific Northwest Quarterly 75, no. 4 (1984): 164n3.

${ }^{23}$ Shamoon Zamir, The Gift of the Face: Portraiture and Time in Edward S. Curtis's "The North American Indian" (Chapel Hill, NC: University of North Carolina Press, 2014), 10.
} 
people he photographed. Zamir builds his argument around the relationships between aesthetics, ethics, and the human experience of time in photography that can be witnessed in the faces in Curtis's portraits of Native Americans. ${ }^{24}$ Zamir notes, "The loss of many tribal traditions and the confinement on reservation lands marked a rupture in the continuities of time and culture for all Native Americans. The time before was their time. What came after was a history to which they had in effect been made subject and to which they had to adapt." ${ }^{25}$ Zamir claims in the introduction to be building on the work of Gidley, among others. His copious quotes demonstrate his wish to develop the dialogue around Curtis's work as well as creating a dialogue with the authors who have come before him.

Edited by Christopher Cardozo, Curtis scholar and collector, and using images from his personal collection, One Hundred Masterworks is one of the few sources that discuss the material aspects of Curtis's work. In his introduction to the book, Cardozo notes that Curtis's gifts as a craftsman and innovator are less acknowledged than his contribution to the ethnographic record of Native Americans. ${ }^{26}$ One Hundred Masterworks brings together a series of essays by Cardozo and other scholars with Cardozo's large and varied collection of Curtis photographs to demonstrate the artistry he achieved in the various mediums. Though scholars publish many books and articles either critiquing or embracing the romanticism of Curtis's approach, there is very little published on his aesthetic achievements.

\section{Cataloguing and Collections Management}

In making this document, I consulted former Film and Photographic Preservation and Collections Management thesis projects that concentrated on creating finding aids, particularly for the AGO. Especially helpful was Zulay Chang's thesis, "A Full Catalogue and Analysis of Photographs and Photogravures by Robert J. Flaherty at the Art Gallery of Ontario." In her thesis, Chang constructed what

\footnotetext{
24 Ibid., 3.

25 Ibid., 69.

${ }^{26}$ Christopher Cardozo, introduction to Edward S. Curtis: One Hundred Masterworks, edited by Christopher Cardozo (New York: Del Monico, 2015), 7.
} 
she calls a catalogue for each image. The catalogues list the essential information for each object, i.e. title, date, dimensions, etc., and information about related objects found at Library and Archives Canada (LAC) and in the AGO collection. One of her goals in creating this catalogue is to pair up negatives found at LAC and the AGO with their corresponding prints. Chang undertook this project as the AGO migrated its catalogue records to TMS. Many of her information fields reflect this. She chose fields based on what the AGO needed in its catalogue records. By creating a catalogue, Chang was able to create a document that could be used by the AGO in their move to TMS and to locate negatives and their corresponding positives.

A more general source is Mary Lynn Ritzenthaler's and Diane Vogt-O'Connor's Photographs: Archival Care and Management (2006). A chapter entitled, "Description and Cataloguing" by Helena Zinkham describes the various access tools used to provide access to a collection. This includes cataloguing records, finding aids, and other resources for intellectual content. The author notes that "access tools make it easier for staff and researchers to search for and discover material; select the most relevant material to consult; locate items to view and reproduce; and understand the materials' origins and evidential value or authenticity." ${ }^{27}$ Moreover, public institutions hold their collections for the public trust, meaning that access to the material by everyone should be a top priority. Accurate and available access tools simplify this process, so that researchers and staff members can use their time efficiently while studying the collection. In this chapter, Zinkham provides the standards that archivists and librarians use in developing access tools. While the AGO's TMS database has complete catalogue records, another access tool in the form of a finding aid or other document can provide even greater access to the Curtis material in the collection.

\footnotetext{
${ }^{27}$ Helena Zinkham, "Description and Cataloguing," in Photographs: Archival Care and Management, by Mary Lynn Ritzenthaler and Diane Vogt-O'Connor (Chicago: Society of American Archivists, 2006), 165.
} 
An article from the journal, The American Archivist by Dennis Meissner illuminates some of the issues in the format of finding aids. These issues and their solutions can be applied to other collections' access tools. His article title, "First Things First: Reengineering Finding Aids for Implementation of EAD” discusses issues archivists faced in the late 1990s as they moved resources online. Meissner discusses elements of finding aids that reduced their efficiency, such as an unclear statement of purpose and contents of the finding aid. The problems that he identified were information fields not clearly identified, information fields not optimally arranged, alternating levels of description, and a lack of user instructions. Addressing the issues listed here will make the resource document for the Curtis works a useful addition to the AGO's collection documentation.

The first part of this literature review contextualizes Curtis's work since its re-emergence in the 1970s while the second part discusses literature that informs the creation of the resource document for the AGO. The literature pertaining to Curtis highlights how as time changes so do the opinions about the photographer and his work. In addition to the finding aid, this review of literature can be used as a tool for researchers and AGO staff. 


\section{Methodology/Development of document}

When creating any kind of descriptive document for a collection, the first step has to be examining the collection. This includes looking at the cataloguing records for the collection, if any, and viewing the physical collection in its entirety. The AGO uses The Museum System (TMS) to organize catalogue records. I first consulted the TMS database for works by Edward Curtis. This gave me the location of all of the objects, of which all but one are stored in the Prints \& Drawings Vault. The film is stored with other films in the AGO collection, in a different vault.

I undertook a thorough examination of the Curtis photographs taking notes on condition, aspects of the materials, and looking for any missing information or inconsistencies. I recorded all of my notes in a Microsoft Excel spreadsheet and then went back to the TMS database to compare my findings side-by-side with the current catalogue records. The investigation uncovered a few spelling mistakes in titles and an inconsistency in the naming of the paper supports of the photogravures, which is discussed later in this paper.

The goal of the resource document is to provide context for the objects. I sorted the photographs according to the order in which they appear in The North American Indian in the same spreadsheet used to take my notes on the collection. Eventually, I transferred all the information I compiled into the spreadsheet to the second part of this thesis. This method of sorting provided an understanding of the significance of certain volumes to the AGO collection.

Much of this information would not be obtainable without viewing the actual volumes that the prints came from. Fortunately, Northwestern University Library has digitized their volumes and portfolios of The North American Indian and made them available online in 2004. Though it is not the same experience as viewing the books in person, the online resource allowed me to identify and order 
the photogravures as Curtis intended for them to appear. Viewing the books online also allowed me to read the text that appears with the images.

In developing the resource document, I relied heavily on Zulay Chang's thesis project. Sophie Hackett, Curator of Photography, encouraged me to use Chang's thesis project because it deals with a similar subject matter, Robert J. Flaherty's photogravures and photographs of Inuit individuals, and because Chang made it for the AGO. For my resource document, I used similar fields as Chang but tailored them to the Curtis collection. For example, all of Curtis's photogravures have page and plate numbers associated with them and thus I have included those numbers in the data I collected.

I developed the document with the goal in mind of creating an intellectual order for the Curtis works that contextualizes them by showing the artist's intended order. All the photogravures are listed according to volume or portfolio. Then I created an extended description of each object that can provide context for the object, background information for exhibitions, or lead researchers to the related text within The North American Indian. The intention of the document is to provide as much contextual information as possible to accompany each photograph. 


\section{Description of AGO Collection}

The AGO collection of Curtis photogravures consists of sixty-five prints in two sizes and on various supports. All of the Curtis prints were gifted to the AGO. In an interview with curator emeritus of photography, Maia-Mari Sutnik, she said that the prints were chosen and acquired for their quality and/or subject matter. Valerie Burton, an art dealer, and David Milman gifted the majority of the Curtis prints in 1985. This gift consisted mostly of photogravures from Volume 11 and one cyanotype. Dr. Joshua Josephson made a gift of five prints in 1991, most of which were from portfolios of The North American Indian. These five prints come from a number of different volumes and may have been selected by the donor for their striking formal qualities. A third gift of three more prints came from John Richmond Harris in 2006. The 2006 acquisition included two prints from Volume 11 that add to the 1985 gifts of works from that volume and a larger print. In 2007, a half-tone postcard came into the collection through an anonymous donation. The AGO acquired the film after 1974.

The images in the AGO collection come in two sizes: smaller photogravures about 7" $X 51 \frac{1}{2}$ " on

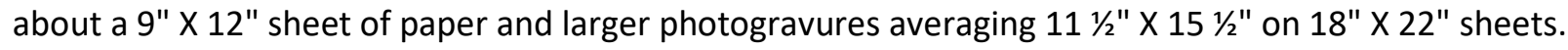
Most of the prints are of the smaller variety that were originally illustrations taken from unbound copies of The North American Indian, from here on referred to as volume prints. The larger prints were made for the accompanying portfolios and will be referred to as portfolio prints. Fifty-five of the AGO photogravures are volume prints and ten are portfolio prints. Three portfolio prints and one volume print are on tissue. The fifty-five volume prints are all on an etching stock, known as Van Gelder. The other seven portfolio prints are on an unidentified paper.

As mentioned above, Curtis used different papers for his photogravures. Subscribers had the option of Dutch Van Gelder paper, a high-quality cotton rag paper that is typical for printmaking; 
Japanese vellum; ${ }^{28}$ or Japanese tissue, which possibly refers to Gampi paper or India proof paper. ${ }^{29}$ The Dutch Van Gelder paper was the cheapest option. The prices ranged from $\$ 3,000$ to $\$ 3,850$ per set based on the quality of the papers, approximately $\$ 75,000$ per set at today's value. Sets printed on Japanese tissue were the most expensive and the rarest today given that only a small number were printed. The most common are printed on Van Gelder paper or vellum.

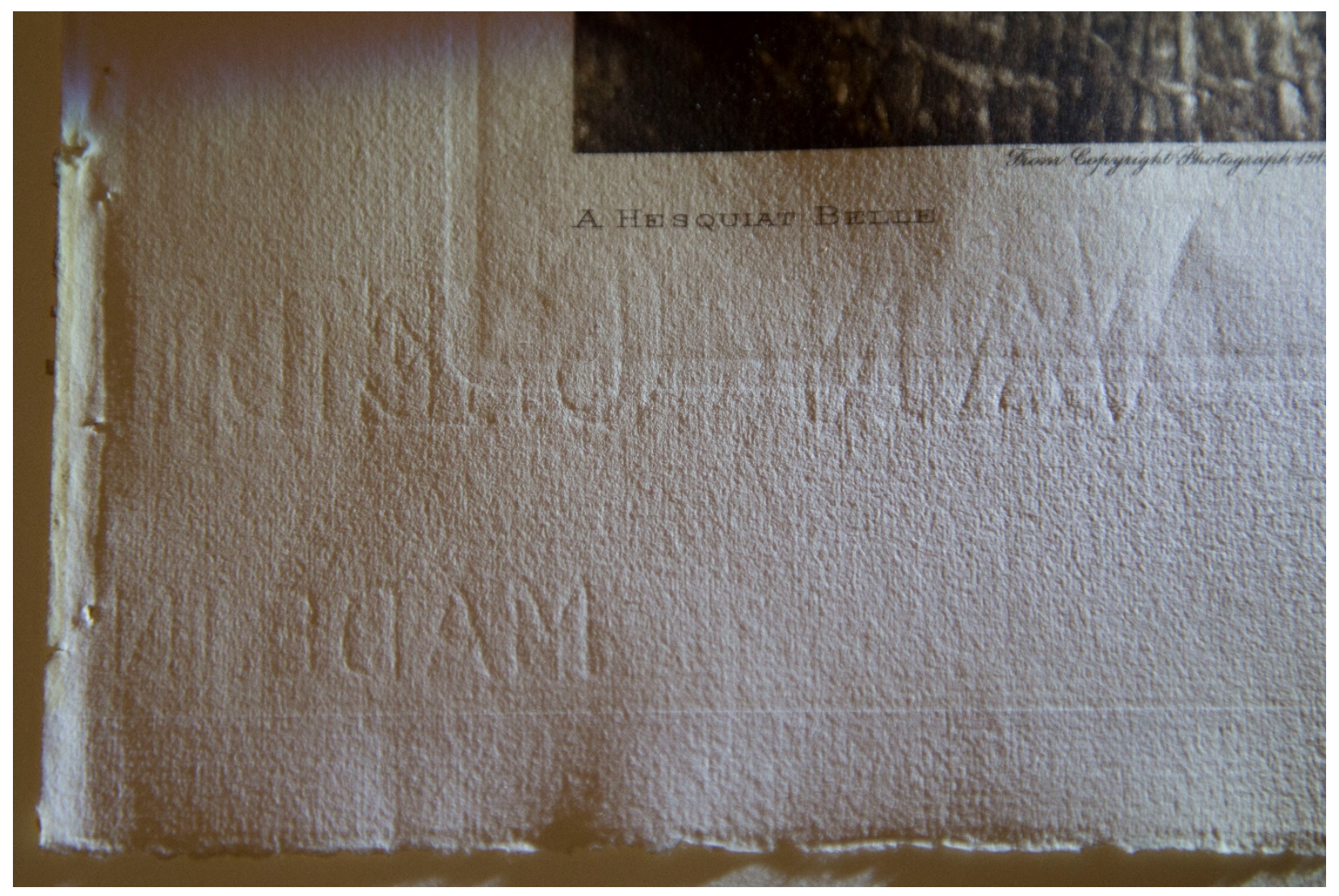

Figure 3. Van Gelder Watermark, seen in raking light. Photograph by author.

Van Gelder is a brand of etching stock from Holland. Van Gelder paper can be identified by a watermark reading, "Van Gelder Zonen / Made in Holland" (Figure 3). It is a cream-colored, very smooth

\footnotetext{
28 "Japanese" is used descriptively and interchangeably with "Japon." Van Gelder is a brand name of an etching paper.

${ }^{29}$ Christopher Cardozo, "A Collector's Guide," Christopher Cardozo Fine Art, accessed June 28, 2017, https://edwardcurtis.com/a-collectors-guide/; Rachel Danzing, and Ann Baldwin, "Pilot Project to Treat Photogravures on Gampi Paper from Edward Curtis' 'The North American Indian,," abstract, in "Treatment 2017: Innovation in Conservation and Collection Care," Abstract Book, 45 (2017): 57-58.
} 
paper. At the time of publishing, Van Gelder was a premium paper. Twenty-eight of the volume prints have watermarks indicating the paper support to be Van Gelder. This is cut off at various points and only partially visible on any of the pages. Given that the paper stock was cut down to the desired page size, on some photogravures the watermark is not visible at all. The one volume print on tissue is mounted to a piece of watermarked Van Gelder paper. Because the rest of the volume prints share a similar color and texture to the watermarked prints, we can deduce they are also on Van Gelder paper.

Of the portfolio prints in the AGO collection seven are on paper and three are on tissue. There appear to be two different papers apart from the tissue. The portfolio prints on paper do not have watermarks and bear little resemblance to the Van Gelder prints. The portfolio prints from the 1985 gift are on a warm-toned, light-weight paper with a smooth texture. The coloring of the paper is irregular and blotchy in appearance setting it apart from the Van Gelder, which has an even coloring. The gift from 1991 contains prints on a heavier stock than the 1985 gift and the tone of the paper is cooler than both the 1985 gift and Van Gelder papers. In a side-by-side comparison, neither resembles Van Gelder paper in color or texture (Figure 4). Knowing that at least one group undertook a reprinting of Curtis's original copper photogravure plates in the 1970s and Curtis only printed on Japanese tissue, vellum, and Van Gelder paper, we can deduce that these images were printed sometime after $1970 .^{30}$

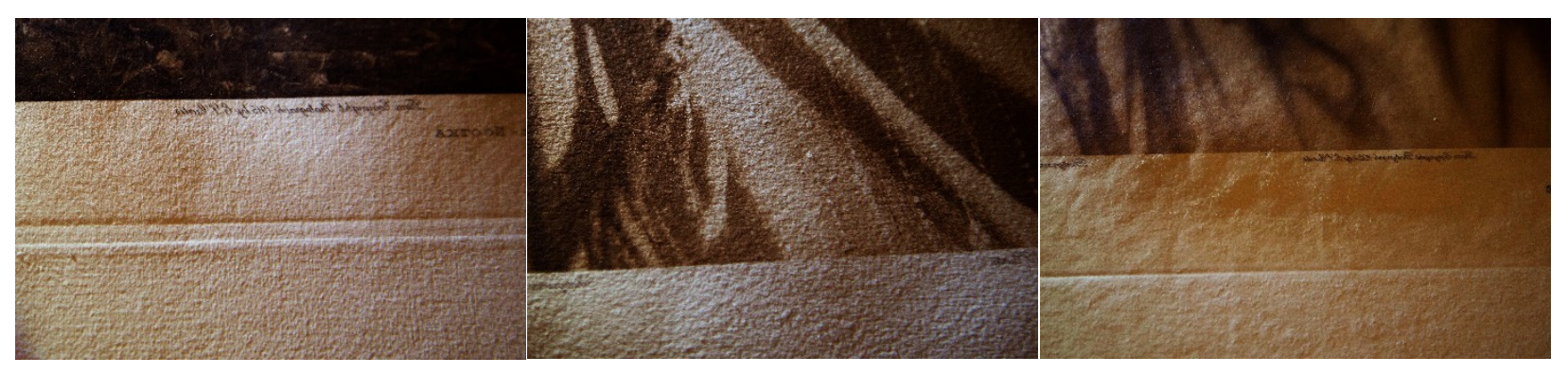

Figure 4. Close-ups in Raking Light on Three Different Etching Stocks. From left to right: Van Gelder paper, Portfolio print from 1991 Gift, Portfolio print from 1985 Gift. Photographs by author.

\footnotetext{
${ }^{30}$ For more information about the reprints, see "Major Holdings of Curtis's work" in Part 2.
} 
The AGO database lists the paper supports for most of the prints as "vellum." As noted above, most of the AGO prints are on Van Gelder paper, a typical etching stock, not a vellum. Curtis had captions for the portfolio prints and I suggested these be added to the database. Working with Assistant Registrar, Stephanie Burdzy, we corrected the paper types and added the captions to TMS.

In searching for more information on the materials Curtis used for the books, I have found conflicting information about Japanese tissue and little about Japanese vellum. Cardozo refers to the Japanese tissue as India proof paper, ${ }^{31}$ though other sources label it Gampi paper; an unsubstantiated source describes the Japanese vellum as a misnomer for a parchment made with rice. ${ }^{32}$ Cardozo identifies the Japanese tissue as India Proof Paper. Also called China paper, this lightweight tissue made from bamboo fibers was used to "proof" printing plates, meaning it was used to identify any flaws in the prints before using the final paper materials. ${ }^{33}$ The amount of detail that could be seen on the paper made it a sumptuous choice for printed illustrations in books, which are usually referred to as plates. Though used in books for etchings at the time, it is an uncommon choice for photographs and photogravures. The North American Indian is unique in its use of this tissue paper.

The collection is stored in four boxes in the AGO's Prints \& Drawings vault (Figure 5). One 24" X 36 " box stores all the portfolio prints in handling mats. The volume prints are stored in two 13" X 19"

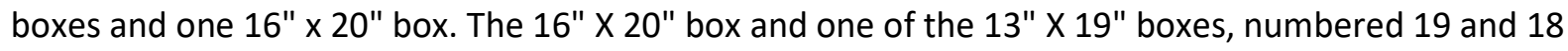
respectively, contain matted prints. Box 17A contains a few matted prints but most prints are unmatted. In total, forty-three prints are matted, while the rest are simply separated by tissue. At the present time,

${ }^{31}$ Cardozo, “A Collector's Guide," https://edwardcurtis.com/a-collectors-guide/.

32 Kevin P. Groark, "E.S. Curtis Print Identification Treatise," Art Vintage Ltd., accessed May 15, 2017, http://artvintage.tripod.com/index-204.html.

${ }^{33}$ Museum of Fine Arts Boston, "India Proof Paper," CAMEO Materials Database, last modified May 1, 2016, cameo.mfa.org/wiki/India_proof_paper ; "China Paper," Bookbinding and the Conservation of Books: A Dictionary of Descriptive Terminology, accessed March 20, 2017, cool.conservation-us.org/don/dt/dt0676.html. 
the volume prints are not sorted by either accession number, subject matter, or by the volume in which they appear in The North American Indian.
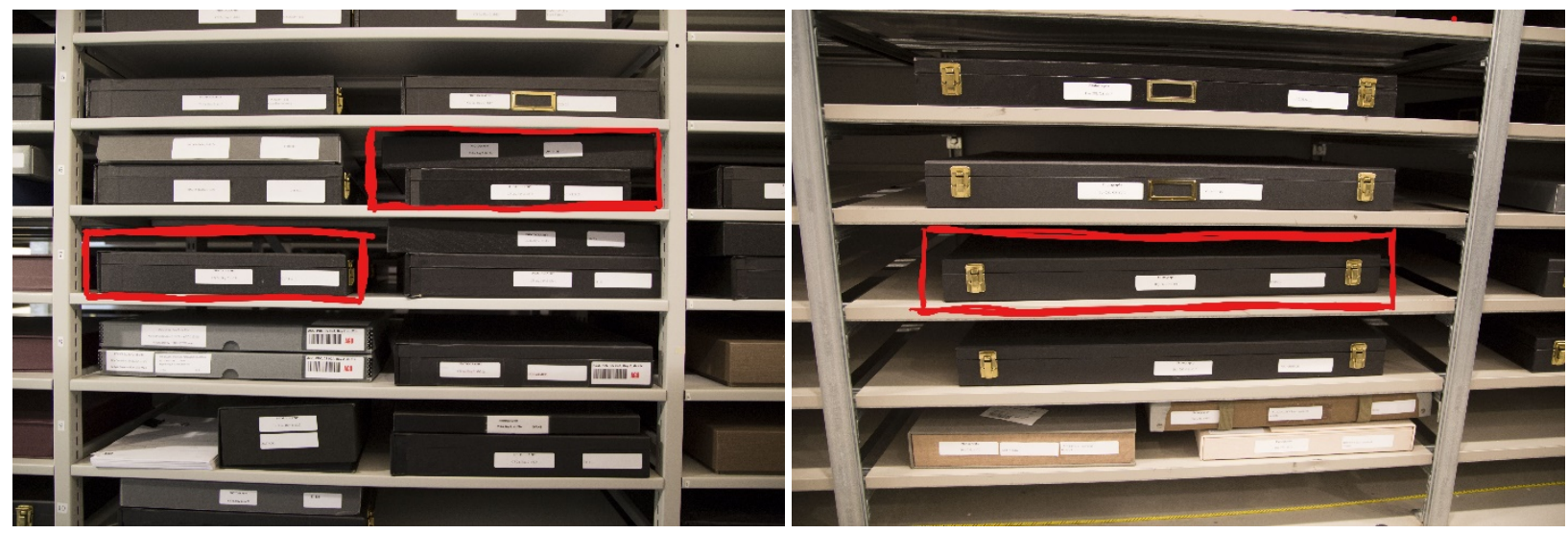

Figure 5. Locations of Boxes on Shelves in the Prints \& Drawings Vault. Photographs by author.

There do not appear to be any signs of deterioration besides some discoloration and some iron-

induced foxing on Old Trail at Acoma. Many of the volume prints show discoloration in the shape of a rectangle beyond the image area (Figure 6). This leads one to believe that it is a result of a more acidic paper or tissue being laid on top of the photogravure. The portfolio prints have a darker discoloration across the image to just inside the plate mark, where a window mat would fall on the print.

Many of the volume prints from the AGO collection have evidence of a binding edge: holes from being sewn into the book, remnants of glue or other bookmaking materials (Figure 7). The E.P. Taylor Research Library and Archives at the AGO has Volume 11 in its holdings. According to the library database, their copy of Volume 11 had the photogravure plates removed and transferred to the AGO Curatorial collection. The volume was then rebound. The library's copy is numbered 129 of 500 . If the book was whole when it was acquired by the $A G O$, then all the photogravure plates from that volume would be in the AGO collection, which is not so. I reason that the volume entered the AGO already unbound. 

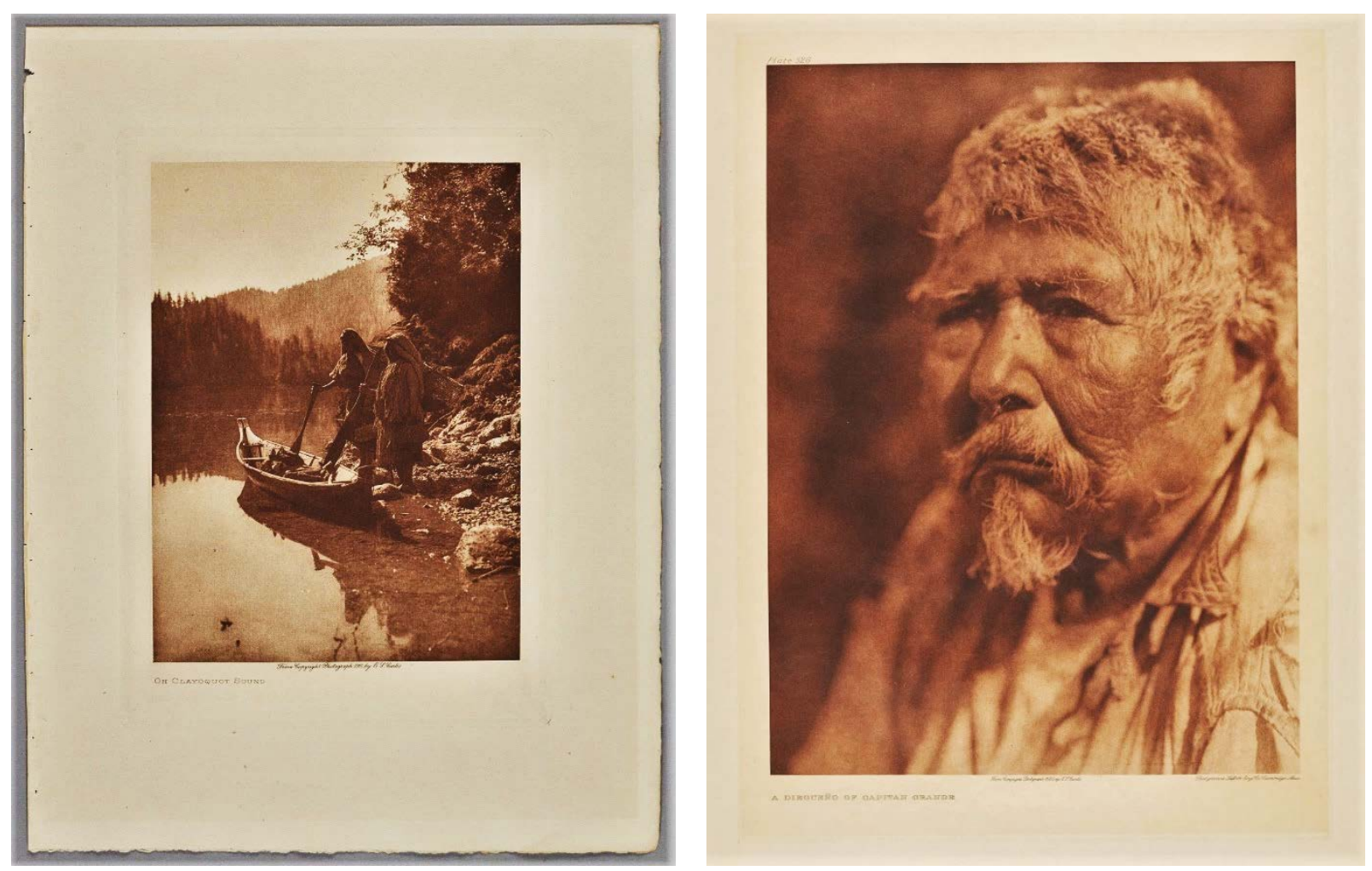

Figure 6. Left: Volume print showing discoloration over whole page. Right: Portfolio print showing discoloration over image. Note: Contrast has been adjusted to better show discoloration. Photographs courtesy of Art Gallery of Ontario.

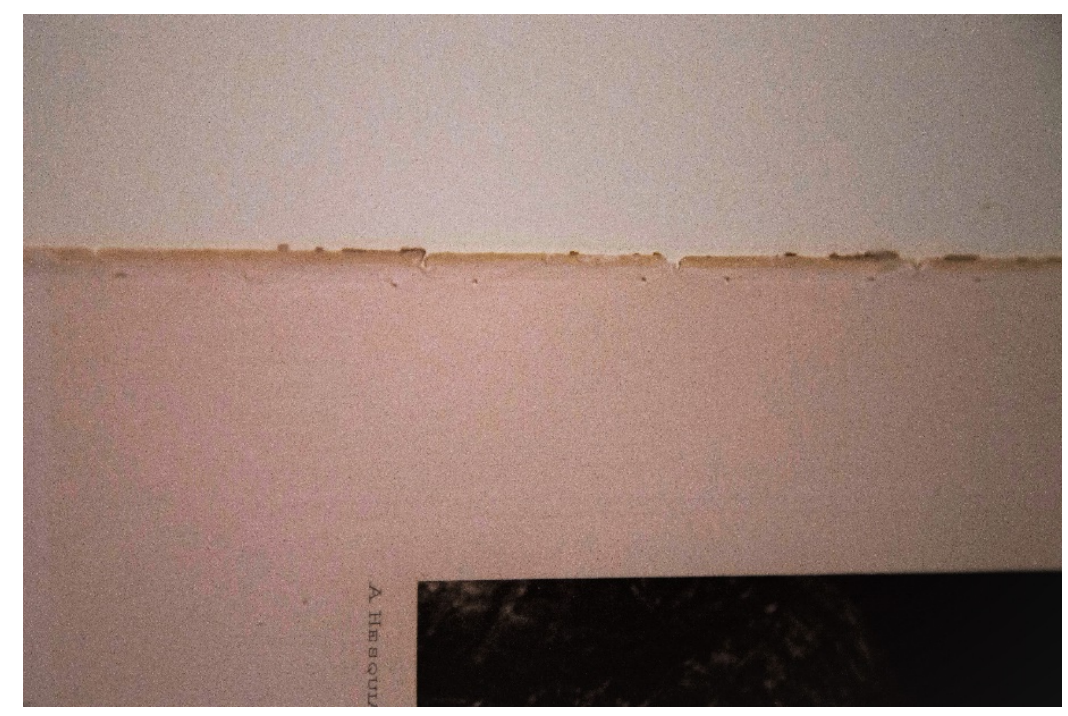

Figure 7. Binding Edge of Volume Print. Photograph by author. 
The volume prints owned by the AGO mostly come from Volume 11, though there are three exceptions: one each from Volumes 3, 10, and 17. The portfolio prints come from portfolios numbered $8,9,10,13,15,16$, and $19 .{ }^{34}$ Concerning subject matter, the prints can be divided into four categories: portraits, landscapes, objects, and genre scenes. These four broad categories generally describe the main subjects of the images. The category of "portrait" was assigned to any image that was a close-up of the face or a subject on a plain background. Landscapes show a wider view of the area or a home. The term "object" was assigned to anything that depicted ephemera, such as baskets, or Native drawings. A genre scene shows anything from everyday life to dances and ceremonies. Of the prints from volume 11, twenty-five are portraits, four are landscapes, eleven are objects, and twelve are genre scenes. Fourteen have a horizontal orientation and thirty-eight are vertical. There are seventy-six prints in Volume 11 and the AGO owns fifty-two from that volume. The groupings of the different categories hints at the amount of time Curtis spent among each tribe. In Volume 5 on the Arikara, for instance, many of the pictures seem to be taken on the same day of the medicine dance. Other volumes, such as volume 1 , have more variety. It features seventy-nine photogravures which can be divided into forty-three portraits, twentynine landscapes, twelve objects, and thirty-four genre scenes. Sixty-two have a horizontal orientation and fifty-eight are vertical. Volume 11 has more of a variety in its subject matter but is dominated by portraits, which is typical for many of the volumes. Curtis spent at least a year in the area where the Nootka and Haida resided because he was also making his film about the Kwakiutl.

Most of the images in the books are portraits - Zamir identifies it as the largest genre of the images in The North American Indian. According to Zamir, "just less than a thousand of the roughly two and a quarter thousand pictures included in the project can be counted as studies of the human face." ${ }^{\prime 35}$

\footnotetext{
${ }^{34} \mathrm{~A}$ list of the individual volumes and their subjects is in the appendix.

${ }^{35}$ Zamir, The Gift of the Face, 30.
} 
Published in 1916, Volume 11 does not divert from the typical model of previous or subsequent volumes of The North American Indian. Volume 11 represents a mid-way point in the project, both because it is the literal middle of the 20 -volume series and because after the publication of this volume, Curtis took a six-year break from publishing. The table of contents for volume 11 shows that the text covers more general information about the Nootka, including a history of European contact with the tribe, war stories, sociological structure, and religious stories, while he includes only religious stories for the Haida. Many of the people in the images from Volume 11 are wrapped in blankets. It was Curtis's practice to ask native subjects to wear "traditional" or "primitive" clothing, whether or not it was still common for them to do so. In his photographs of the Nootka and Haida, the subjects wear cedar-bark skirts and woven reed "blankets." The landscapes of Volume 11 are mostly views of the villages or their surroundings. The genre scenes depict what is meant to be everyday life, but they tend towards a romantic view of times passed. "Gathering Seaweed" (See page 68) and "On Clayoquot Sound" (See page 45) at first glance appear as though they are events that happened but are too picturesque to be events that Curtis stumbled upon. The only objects depicted are totems and pipes. 


\section{Conclusion}

This thesis provides a resource document with detailed information about the AGO's holdings of Edward S. Curtis photogravures and other visual materials as well as an overview of the literature about him. The document combines illustrations, catalogue records, and further details to provide greater access to and background information on the collection. Researchers and curators at the AGO will be able to use the information compiled here to inform future exhibitions and research.

In creating this document, I have established an intellectual arrangement of the Curtis material. This intellectual arrangement provides a framework for future researchers to build around. The importance of Curtis's original and intended order should not be underestimated when evaluating and critiquing the photographs.

The literature review in the first part of this thesis will also provides a guide to the changing reception of The North American Indian over time since its inception to the contemporary. The differing opinions since its rediscovery in the 1970 s will give researchers an idea of the issues that continue to surround the work.

The view of Curtis's work continues to evolve and grow as its complexities become more apparent. Though his work is popular and well-known, the material in the AGO is not often displayed. Through exhibition, a discussion of the cultural significance of Curtis's work to Canada could emerge. Undoubtedly, further research into Curtis's work and its significance will happen because of its enduring popularity. Inquiry into the AGO collection could elucidate why these works are important cultural objects for Canada and housed in a prominent art institution in Canada. 
Part 2: Resource Document 
RESOURCE DOCUMENT FOR THE EDWARD S. CURTIS COLLECTION

AT THE ART GALLERY OF ONTARIO 


\section{Introduction}

This resource document is for the Art Gallery of Ontario (AGO) staff and outside researchers interested in the Edward S. Curtis material in the collection. The collection consists of 65 photogravures, 1

cyanotype, 1 post card, and 1 film. The resource includes background information about the publication, The North American Indian, and other major holdings of Curtis's work. The collection material is divided into three sections: volume prints, portfolio prints, and other works. Volume and portfolio prints are listed in the order that the images appear in The North American Indian. Included in the appendices are a list of all the volumes, a chronology of Curtis's project and career, a description of the photogravure process, and transcriptions of articles by Curtis.

\section{About The North American Indian}

The North American Indian: Being A Series of Volumes Picturing and Describing the Indians of the United States, the Dominion of Canada, and Alaska (1907-1930) is a set of 20 volumes documenting 80 different tribes of the North American continent by Edward S. Curtis (1868-1952). The volumes and portfolios of The North American Indian contain 2,226 photogravure plates in total, of which 723 are separate portfolio prints, enclosed in folded leather folios. Each volume contains approximately 75 prints. The first volume was published in 1907 and the final volume published in 1930 . The ethnographic study concentrated on indigenous tribes still living west of the Mississippi River. Each subscriber had the choice of three different papers for the illustrations and accompanying portfolios: Van Gelder paper, Japanese vellum, or Japanese tissue. The AGO collection contains mostly works from Volume 11 on the Nootka and Haida, who are located along the west coast of British Colombia, Canada.

\section{Guide to the Document}

Each page describes a single object and includes an image, catalogue information, and an extended description which provides contextual information. There are nine information fields for all the objects 
and six fields used where applicable. The fields are listed below in the order that they appear with each object:

- Accession Number: This is the unique item number assigned by the AGO to all objects in the permanent collection. The first two digits represent the year of accession followed by a number representing the consecutive number of donations in the accession year.

- Photographer: This field records the creator of the image, Edward S. Curtis, followed by dates of his birth and death in parentheses.

- Director: Like the photographer field, this records the creator of the film, Edward S. Curtis, followed by birth and death dates in parentheses. Only used for film.

- Title: The title of the work provided by Curtis. Most titles appear on the recto of the photogravure in the bottom left below the image.

- Date: This field lists the date given on the object, which is the copyright and negative date. Copyright dates appear on most photogravures centered just below the image and differ from the date of publication of the volume or portfolio.

- Medium: The process or medium with which each work is produced. For the photogravures, paper types are also listed: Van Gelder paper, Japanese tissue, or, if the specific type is unknown, unknown paper stock.

- Dimensions: The physical dimensions of the object in height by width.

- Running Time: This field records the length of the film in minutes. Only used for film.

- Notes: This is a free text field that contains any information that does not conform to any other field.

- Provenance: This field lists the donor(s) of each object.

- Plate Number/Volume facing page: This field contains the plate number given to portfolio prints or the number of the facing page of the volume print. Each plate number appears in the 
upper left corner of each portfolio print. Volume prints are unnumbered, so the numbered facing page of text is given to represent its location within The North American Indian.

- Caption: This field contains the artist's original caption from a separate sheet that accompanied each portfolio.

- Subject: I have developed four categories to generally describe the subject of the images: portraits, landscapes, objects, and genre scenes. These four broad categories generally describe the main subjects of the images. The category of "portrait" was assigned to any image that was a close-up of the face or a subject on a plain background. Landscapes show a wider view of the area or a home. The term "object" was assigned to anything that depicted ephemera, such as baskets, or Native drawings. A genre scene shows anything from everyday life to dances and ceremonies.

- Constituents: This field records other creators affiliated with the production of the work. Only listed on photogravures and film.

- Related Objects in The North American Indian (NAI): This field provides information on related objects printed from the same negative in The North American Indian. Information on where the image can be found in NAl is noted. Only listed for cyanotype, postcard, and film.

All images are courtesy the Art Gallery of Ontario, except where otherwise noted.

Note on citations: When quoting from the volumes and portfolios of The North American Indian, the citation appears in parentheses after the quotation and lists the volume or portfolio number and page number. Example: (NAI volume 11: page 3) 


\section{Volume Prints}

Volume 3: Teton Sioux, Yanktonai, and Assiniboin, 1908

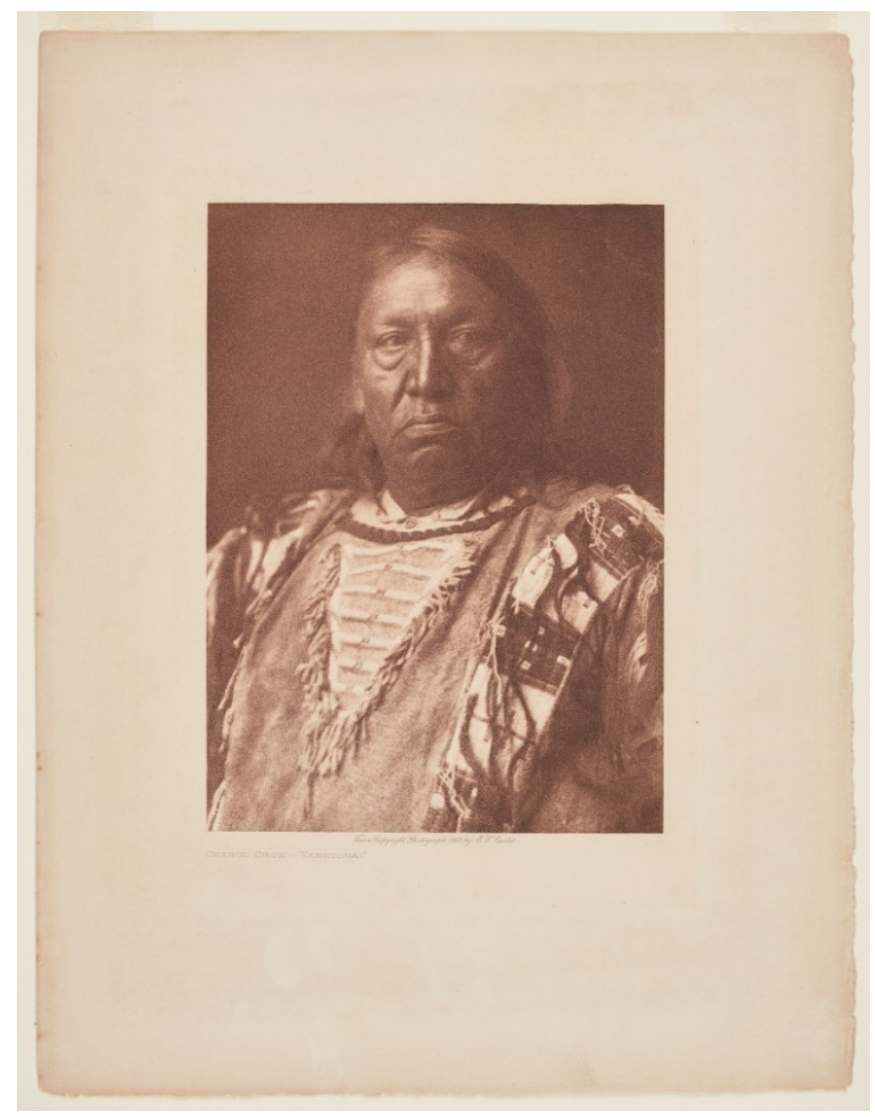

Accession Number: 85/615.8

Photographer: Edward S. Curtis (1868-1952)

Title: Charge Crow - Yanktonai

Date: 1908

Medium: Photogravure, Van Gelder paper

Dimensions: image: $18.6 \times 13.5 \mathrm{~cm}(75 / 16 \times 5$

$5 / 16$ in), plate: $23 \times 17 \mathrm{~cm}\left(9 \frac{1}{16} \times 6 \frac{3 / 4}{\mathrm{in}}\right)$,

sheet: $31.3 \times 24.2 \mathrm{~cm}\left(12 \frac{3}{8} \times 9 \frac{1}{2}\right.$ in $)$

Notes: Discoloration on back, watermark

across bottom

Provenance: Gift of Valerie Burton \& David

Milman, 1985

Facing Page: 180

Subject: Portrait

Constituent: John Andrew \& Son

“Charge Crow, Ka"hí-watákpeye

"Yanktonai. Born near Standing Rock in 1850. When in his seventeenth year he joined a warparty against the Apsaroke near the Little Bighorn, the Yanktonai capturing a number of horses. While fighting the Flatheads, Charge Crow killed one and took his horse. He led a war-party on foot, and encountering the Atsina near Fort Belknap, Montana, captured fifty horses. Having found an old police badge, he visited a camp of Cree and told them he was an officer. They believed him, and Charge Crow stole most of the horses in the camp and got away with them safely. Although he fasted often and prayed to the sun, he never had a vision; he attributes his success in war to the potency of his prayers. He married at twenty-one." (NAI volume 3: page 183) 


\section{Volume 10: Kwakiutl, 1915}

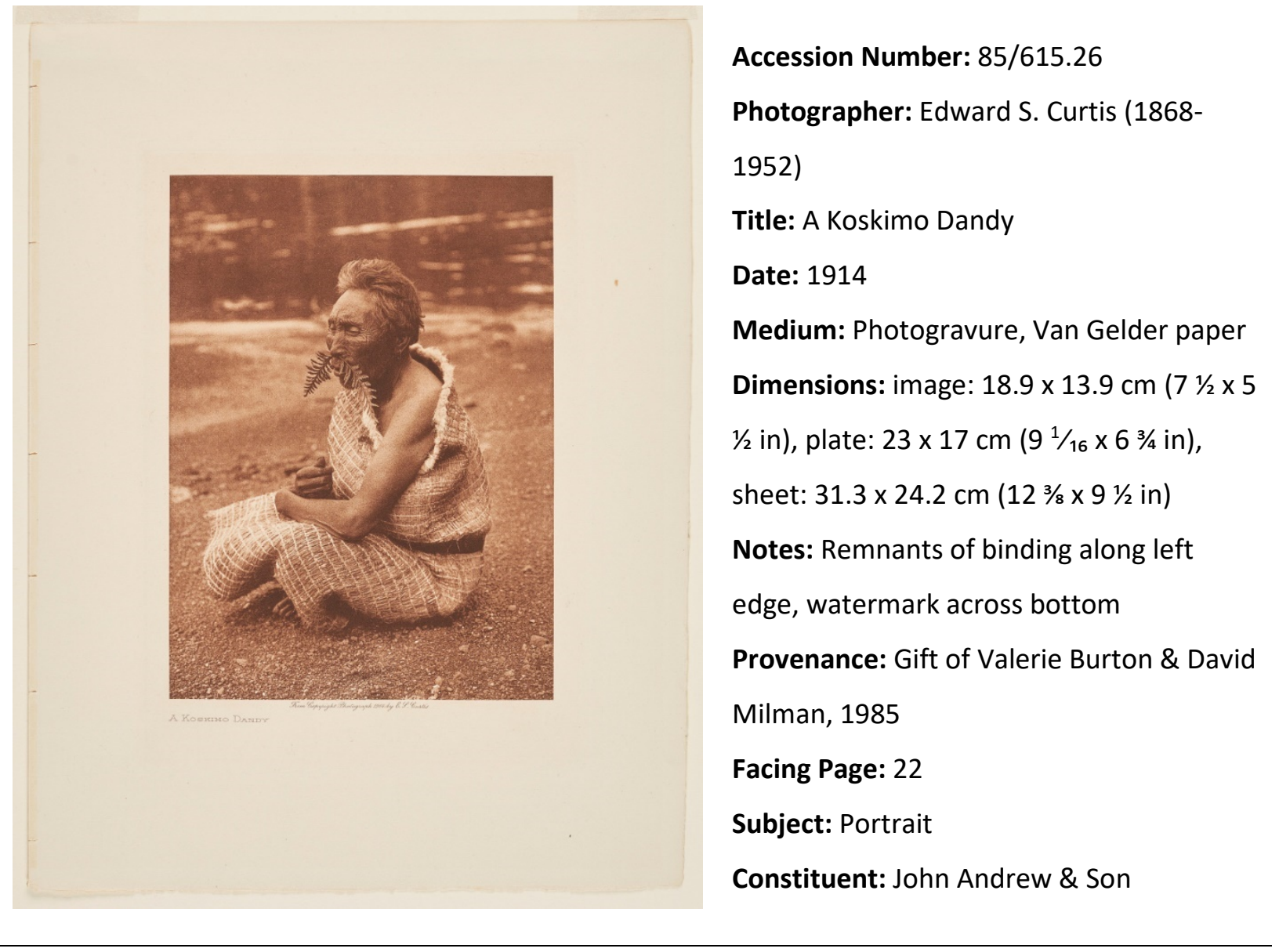

Throughout the North American Indian, Curtis refers to certain male subjects as "dandies." Used more commonly in the nineteenth century, the word "dandy" means a man devoted to style and fashion. Curtis uses "dandy" and "belle" to refer to male and female subjects of his photographs. He used these words to highlight what he saw as the epitome of fashion and beauty for each tribe. 
Volume 11: Nootka and Haida, 1916

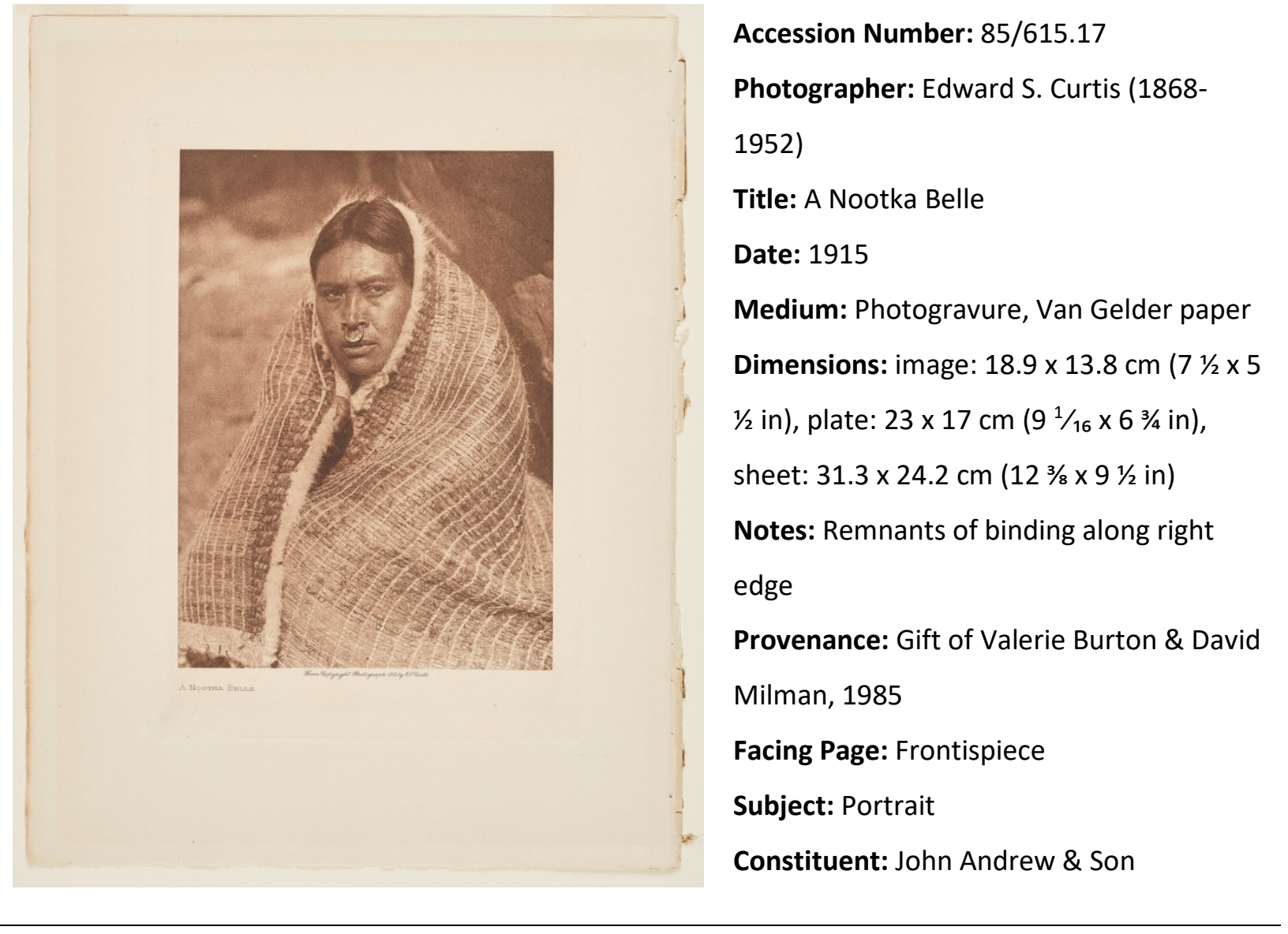

Curtis included at least one photograph of a "belle" for each tribe. Like his use of the word "dandy," he uses "belle" to refer to a female subject that highlights the fashion and beauty standards of a tribe.

Like many of Curtis's subjects throughout The North American Indian, this one is wrapped in a cedarbark cape edged with fur. Curtis used blankets or other types of coverings to obscure modern clothing and in order to evoke a sense of Native Americans as they were pre-contact with the settlers. This cape appears to be similar to the one in "A Koskimo Dandy" from Volume 10. Cedar-bark was used in the making of clothing, blankets, and mats, but Curtis does not record anything more specific about the making of textiles in the Nootka or Haida tribes.

Possibly same subject as 85/615.23 and plate 366 . 


\section{Volume 11}

Accession Number: 85/615.38

Photographer: Edward S. Curtis (1868-

1952)

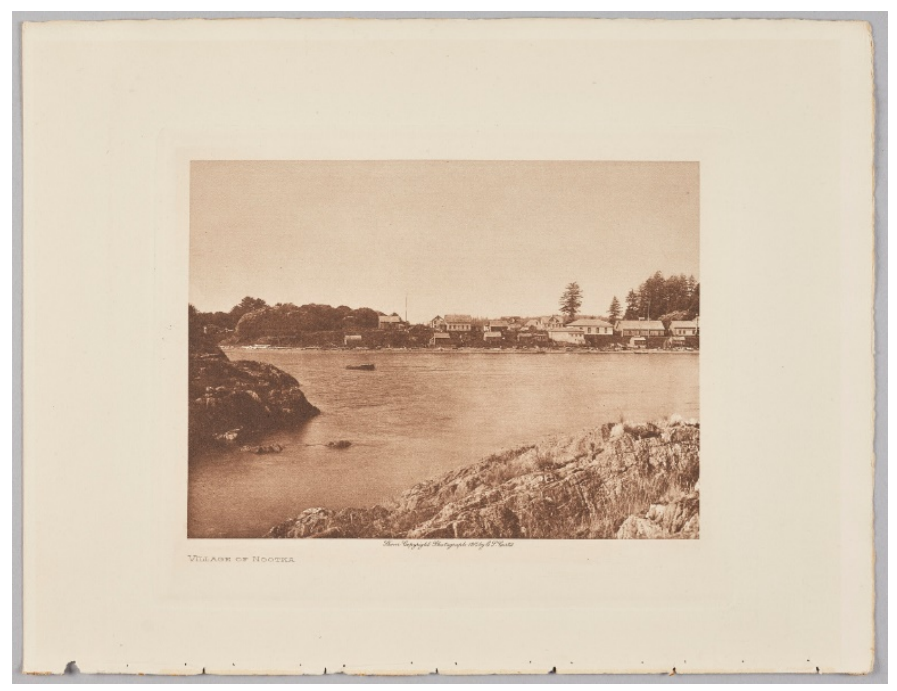

Title: Village of Nootka

Date: 1915

Medium: Photogravure, Van Gelder paper Dimensions: image: $13.8 \times 18.6 \mathrm{~cm} \mathrm{(5} \mathrm{1/2} \times 7$

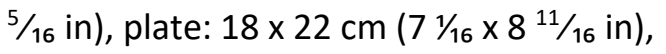
sheet: $24.2 \times 31.3 \mathrm{~cm}\left(9 \frac{1}{2} \times 12 \mathrm{3} / 8\right.$ in)

Notes: Remnants of binding along bottom edge, watermark

Provenance: Gift of Valerie Burton \& David Milman, 1985

Facing Page: 4

Subject: Landscape

Constituent: John Andrew \& Son

This village is most likely one found along Nootka Sound, also known as King George's Sound. The Sound separates Nootka Island from Vancouver Island and is still populated today. The word "nootka" was mistakenly applied to the people of the island and sound by Europeans but actually means "go around." The people call themselves Nuu-chah-nulth which means "along the outside (of Vancouver Island)." 


\section{Volume 11}

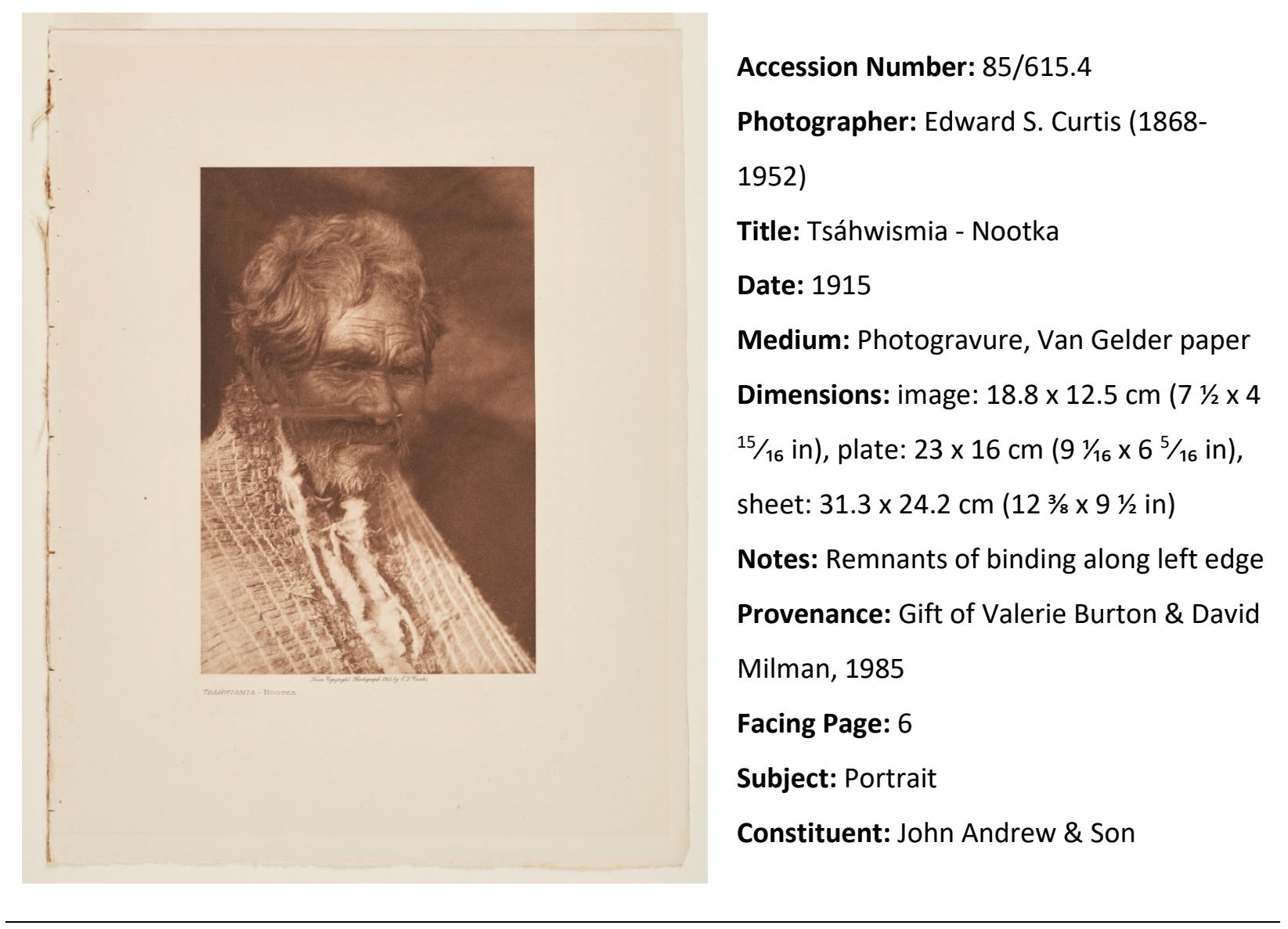

This man is wearing a cedar-bark cape trimmed with fur, a traditional garment, and what appears to be a feather in his nose piercing.

"Chiefs wore abalone-shell pendants in the lowest [piercing in the ear], and feathers of the eagle, owl, or hawk in the others. This of course was only for special occasions. At such times common men placed in each hole a small plug of syringa wood with streamers of yellow-cedar bark fastened to the ends, and in the nasal septum a thin, four-inch sliver" (NAI volume 11: page 11) 


\section{Volume 11}

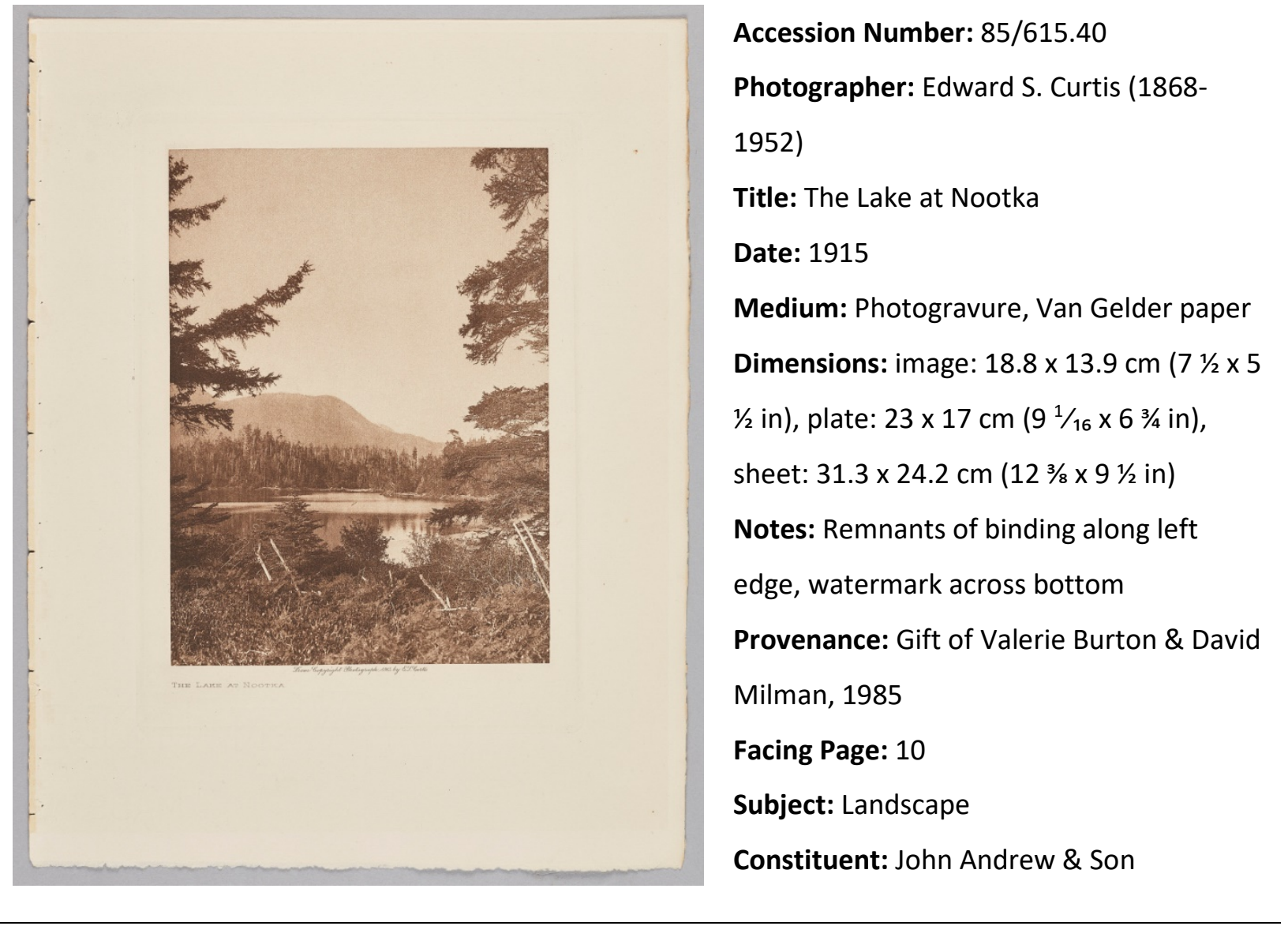

These kinds of landscapes appear in the first few plates of the Volume and provide a setting for the images that follow. 


\section{Volume 11}

Accession Number: 85/615.37

Photographer: Edward S. Curtis (1868-

1952)

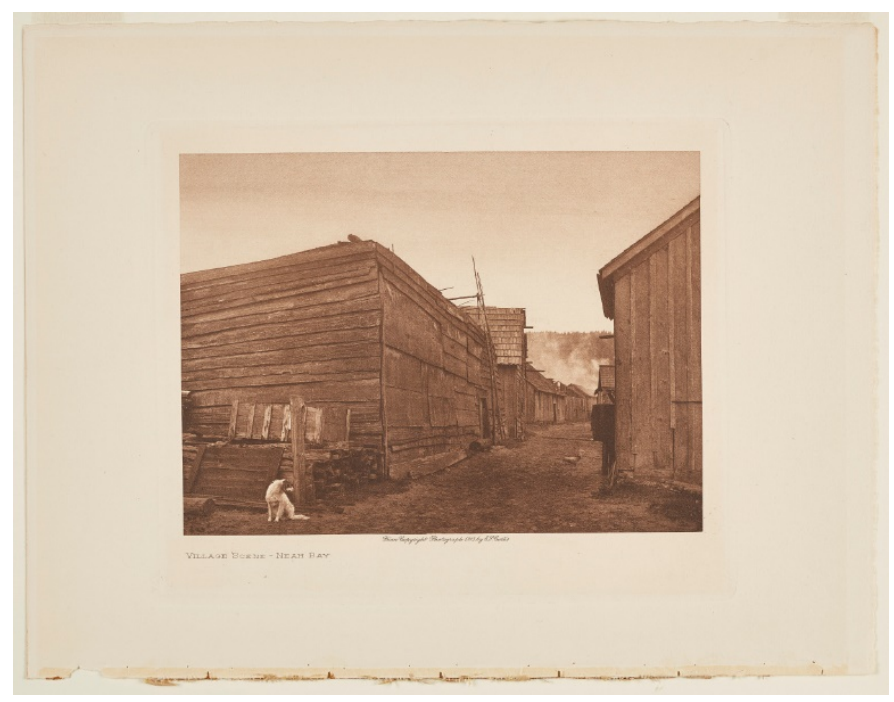

Title: Village Scene - Neah Bay

Date: 1915

Medium: Photogravure, Van Gelder paper

Dimensions: image: 14 x $19 \mathrm{~cm}(5$ 1/2 x 7 1/2

in), plate: $18 \times 22 \mathrm{~cm}\left(7 \frac{1}{16} \times 8 \frac{11 / 16}{\mathrm{in}}\right)$, sheet: $24.2 \times 31.3 \mathrm{~cm}\left(9 \frac{1}{2} \times 12 \frac{3}{8} \mathrm{in}\right)$

Notes: Remnants of binding along bottom edge, watermark across left side

Provenance: Gift of Valerie Burton \& David Milman, 1985

Facing Page: 14

Subject: Landscape

Constituent: John Andrew \& Son

"The primitive Nootka house had a roof sloping from front to rear and supported by beams running in the same direction, which in turn rested on heavy posts. The wall-boards were horizontal. The house with roof sloping from the middle to both sides was apparently an innovation from the east coast of Vancouver Island." (NAI volume 11: page 178) 


\section{Volume 11}

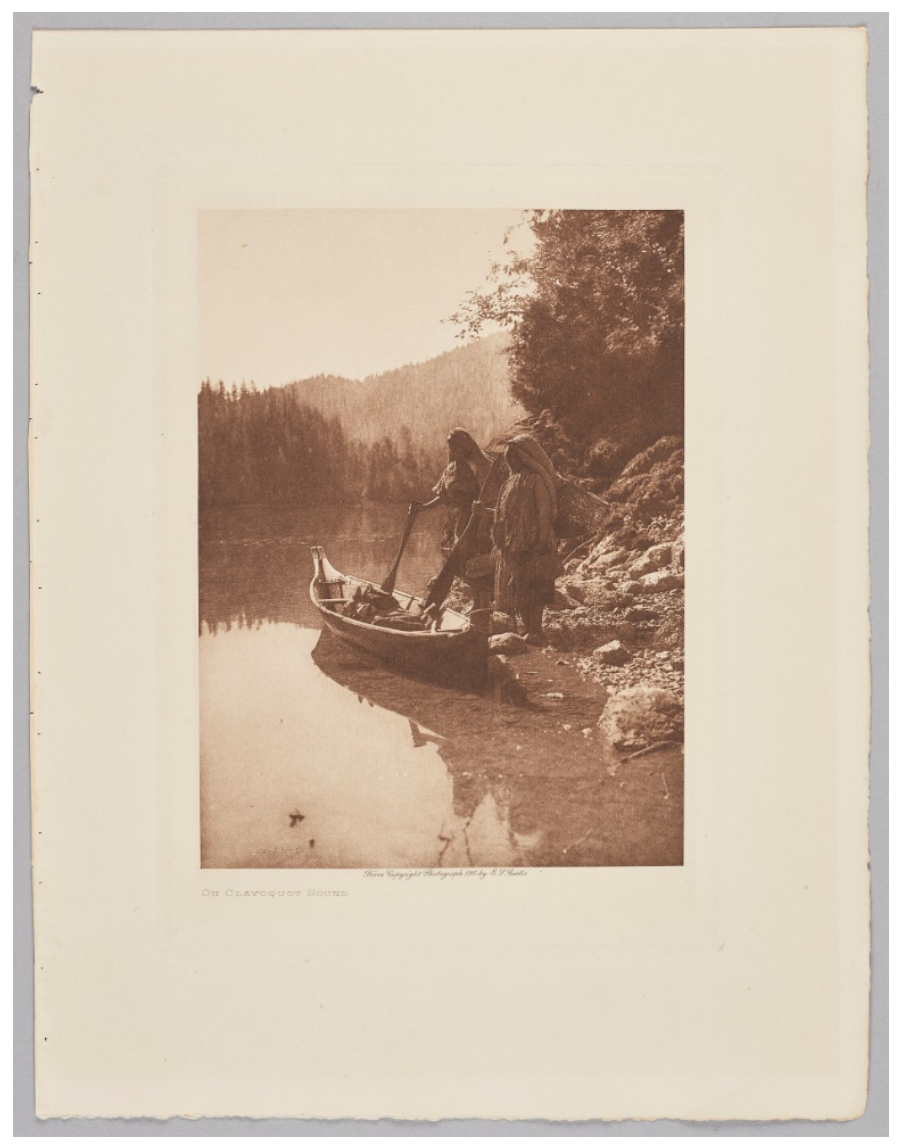

Accession Number: 85/615.39

Photographer: Edward S. Curtis (1868-

1952)

Title: On Clayoquot Sound

Date: 1915

Medium: Photogravure, Van Gelder paper

Dimensions: image: $18.7 \times 13.9 \mathrm{~cm} \mathrm{(7} \mathrm{3/8} \times 5$

$1 / 2$ in), plate: $23 \times 17 \mathrm{~cm}\left(9 \frac{1}{16} \times 6 \frac{3}{4} \mathrm{in}\right)$,

sheet: $31.3 \times 24.2 \mathrm{~cm}\left(123 / 8 \times 9 \frac{1}{2}\right.$ in)

Notes: Remnants of binding along left edge

Provenance: Gift of Valerie Burton \& David Milman, 1985

Facing Page: 18

Subject: Genre Scene

Constituent: John Andrew \& Son

Curtis was an autodidact and in the articles that he wrote, ${ }^{1}$ he encouraged amateurs to educate

themselves on the techniques of great artists of all mediums, which we can reason Curtis also did. This image shows some of Curtis's familiarity with the ideas of Pictorialism. Both the title and the posing of the figures gives the impression of a scene being set and a story being told. The figures are paused on the rocks by their canoe.

\footnotetext{
${ }^{1}$ See Appendices $\mathrm{D}$ and $\mathrm{E}$
} 


\section{Volume 11}

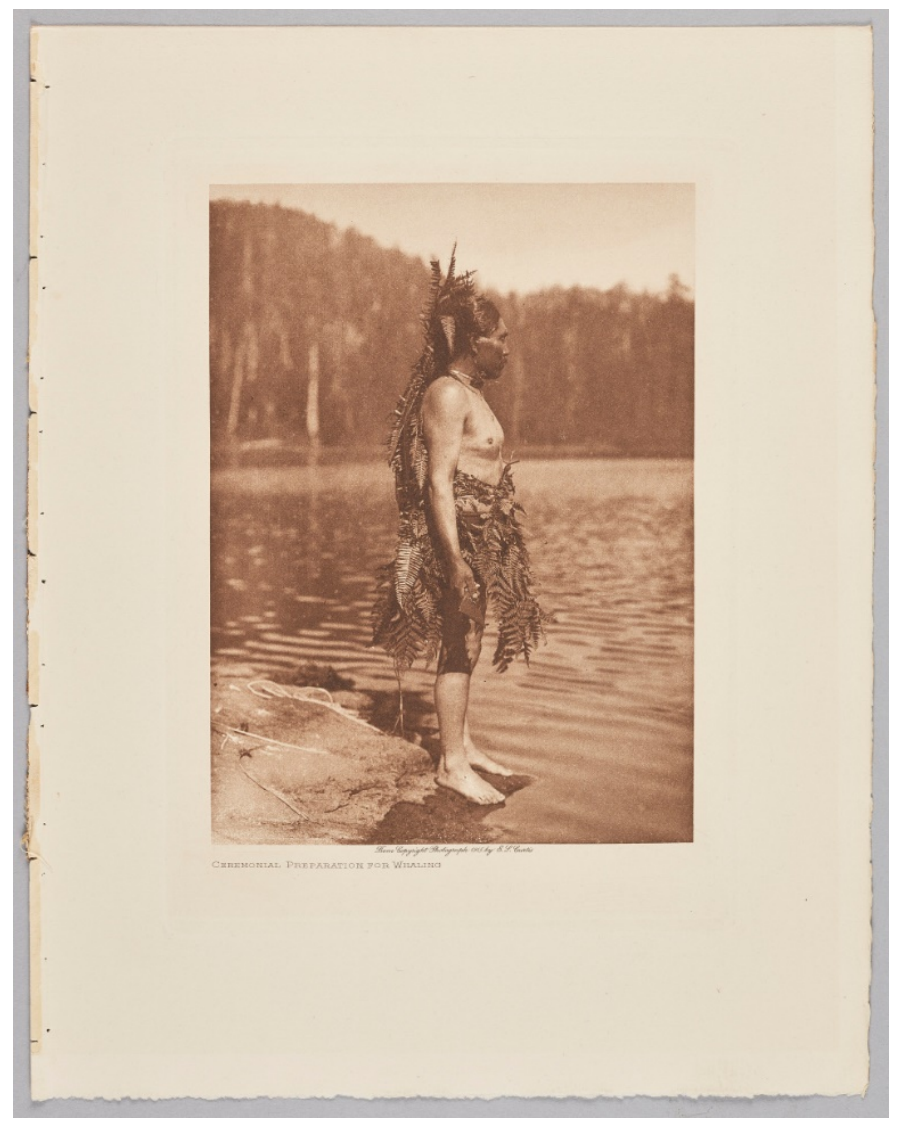

Accession Number: 85/615.27

Photographer: Edward S. Curtis (18681952)

Title: Ceremonial Preparation for Whaling Date: 1915

Medium: Photogravure, Van Gelder paper

Dimensions: image: $18.9 \times 13.9 \mathrm{~cm}(7 \mathrm{1} / 2 \times 5$ $1 / 2$ in), plate: $23 \times 17 \mathrm{~cm}\left(9^{1 / 16} \times 6 \frac{3}{4} \mathrm{in}\right)$, sheet: $31.3 \times 24.2 \mathrm{~cm}(123 / 8 \times 91 / 2 \mathrm{in})$

Notes: Remnants of binding along left edge Provenance: Gift of Valerie Burton \& David Milman, 1985

Facing Page: 20

Subject: Genre Scene

Constituent: John Andrew \& Son

"Prayers and numerous songs form a part of every whaler's ritual. The secrets of the profession are handed down from father to son. As soon as the boy is old enough to comprehend such matters and to remember his father's words, he is permitted to accompany the whaling crew on short expeditions. Now also begins his instruction concerning the most propitious spots for ceremonial bathing - places in lakes and rivers considered most dangerous. At the age of perhaps twelve he is taken at night and shown how to bathe and to rub his body with hemlock sprigs so as to remove the human taint and render the body acceptable to the whale spirit which is being supplicated." (NAI volume 11: page 16)

See also “A Shaman or Medicine Woman" 85/615.25. 


\section{Volume 11}

Accession Number: 85/615.34

Photographer: Edward S. Curtis (1868-

1952)

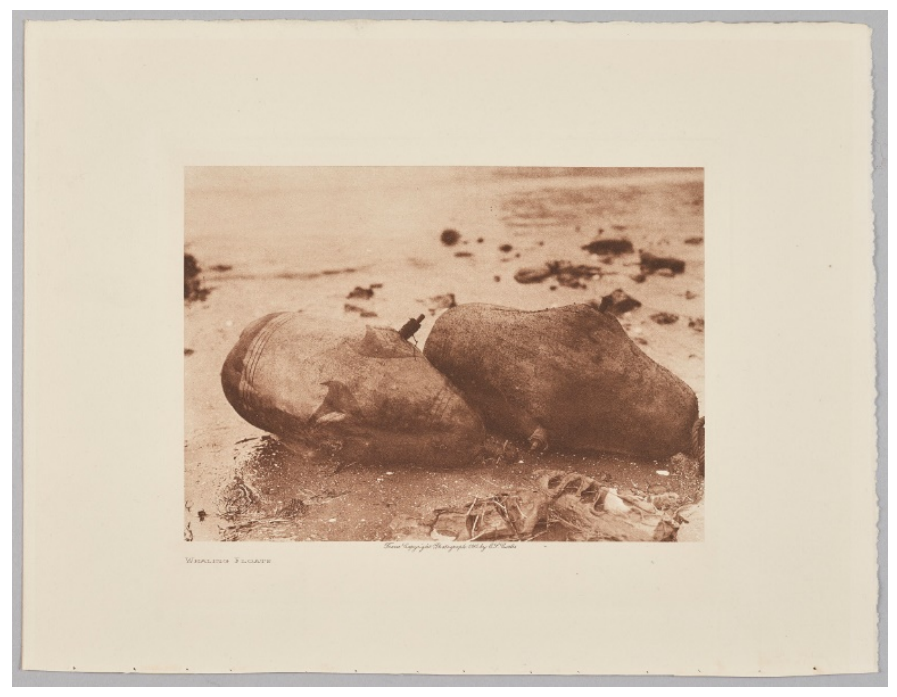

Title: Whaling Floats

Date: 1915

Medium: Photogravure, Van Gelder paper

Dimensions: image: $13.7 \times 18.8 \mathrm{~cm}(5$ 3/8 $\times 7$

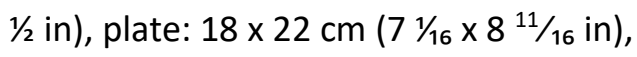

sheet: $24.2 \times 31.3 \mathrm{~cm}\left(9 \frac{1}{2} \times 12 \frac{3}{8} \mathrm{in}\right)$

Notes: Watermark across right side

Provenance: Gift of Valerie Burton \& David

Milman, 1985

Facing Page: 26

Subject: Object

Constituent: John Andrew \& Son

These floats are tied to harpoons during whale hunts. They keep the whale afloat after it has been killed. Four of the images in the AGO collection deal with whaling and nine in the entirety of Volume 11 . Much of the text focuses on different aspects of whaling.

Other whaling images: 85/615.27, 85/615.36, 85/615.45. 


\section{Volume 11}

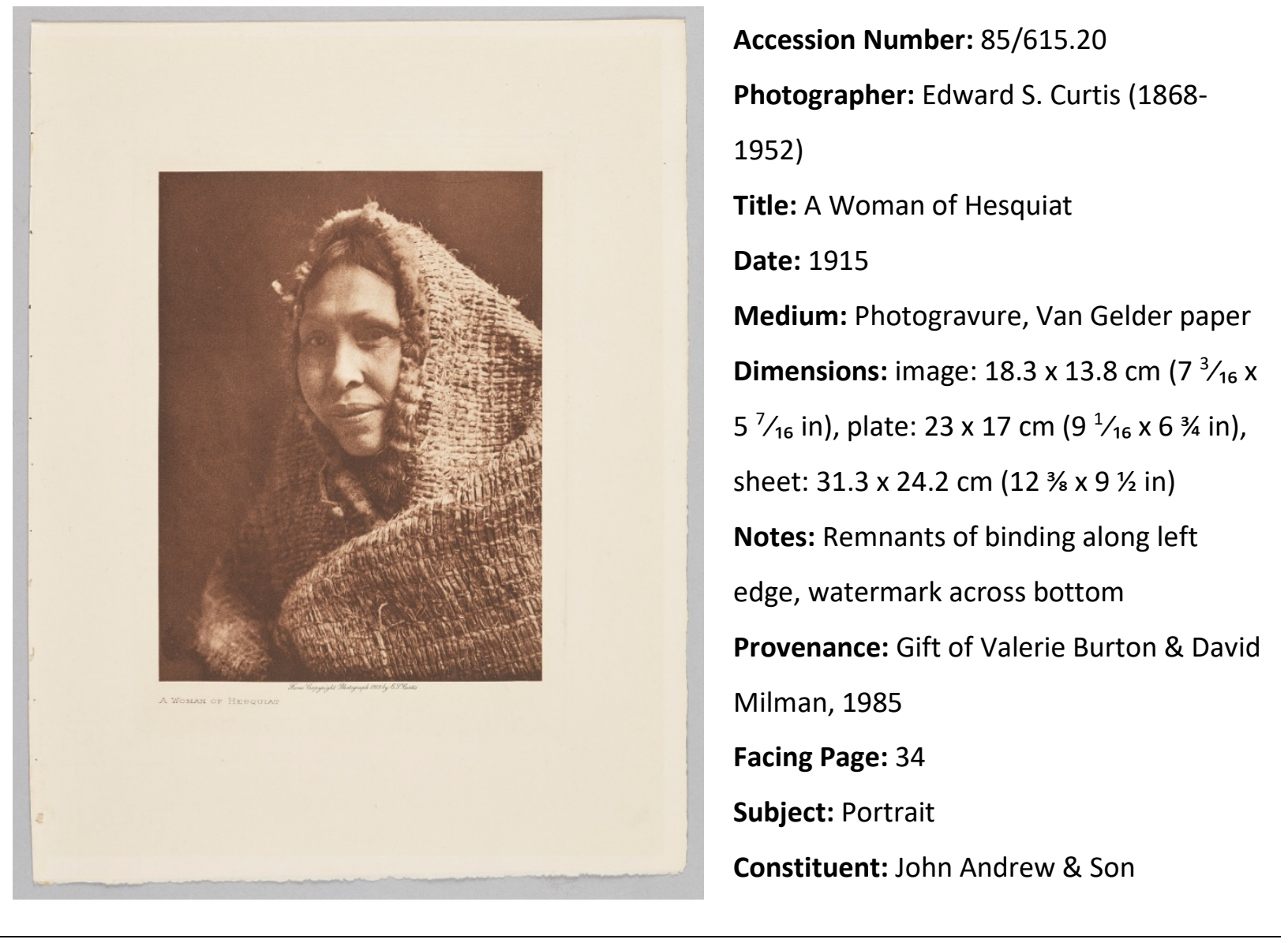

The Hesquiat peoples are affiliated with the Nootka tribe and in Curtis's time populated the area around Hesquiat Harbour on the west coast of Vancouver Island.

This woman is also wrapped in a woven blanket. Curtis notes that on rainy days the Nootka peoples donned ponchos woven from cedar-bark. 


\section{Volume 11}

Accession Number: 85/615.36

Photographer: Edward S. Curtis (1868-

1952)

Title: A Partially Cut Up Whale

Date: 1915

Medium: Photogravure, Van Gelder paper

Dimensions: image: $13.9 \times 18.7 \mathrm{~cm} \mathrm{(5} \mathrm{1/2} \mathrm{x} 7$

$3 / 8$ in), plate: $18 \times 22 \mathrm{~cm}(71 / 16 \times 811 / 16 \mathrm{in})$,

sheet: $24.2 \times 31.3 \mathrm{~cm}\left(9 \frac{1}{2} \times 12 \frac{3}{8} \mathrm{in}\right)$

Notes: Remnants of binding along bottom

Provenance: Gift of Valerie Burton \& David

Milman, 1985

Facing Page: 36

Subject: Object

Constituent: John Andrew \& Son

Other whaling images: 85/615.27, 85/615.34, 85/615.45. 


\section{Volume 11}

Accession Number: 85/615.45

Photographer: Edward S. Curtis (1868-

1952)

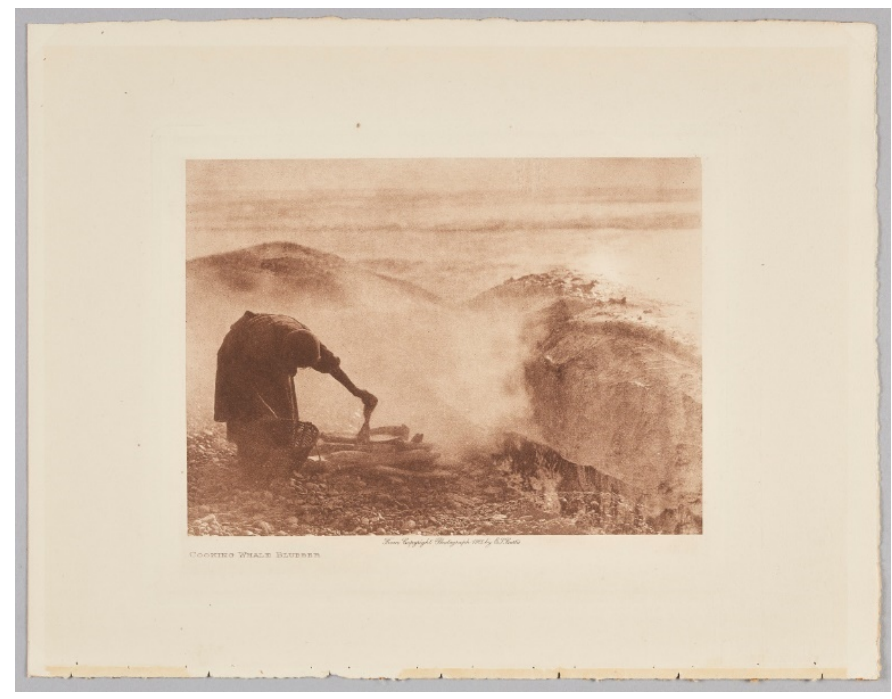

Title: Cooking Whale Blubber

Date: 1915

Medium: Photogravure, Van Gelder paper

Dimensions: image: $13.8 \times 18.8 \mathrm{~cm} \mathrm{(5} \mathrm{1/2} \times 7$

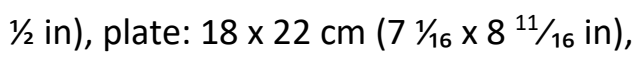

sheet: $24.2 \times 31.3 \mathrm{~cm}\left(9 \frac{1}{2} \times 12 \frac{3}{8} \mathrm{in}\right)$

Notes: Remnants of binding along bottom

edge, watermark across right side

Provenance: Gift of Valerie Burton \& David

Milman, 1985

Facing Page: 40

Subject: Genre Scene

Constituent: John Andrew \& Son

"The blubber is boiled in large chests by means of heated stones, and the oil is skimmed off and stored in a skin, to be eaten with fish, berries, and roots....The cooked blubber, as well as the flesh of the whale, is dried in sun and smoke." (NAI volume 11: page 40)

Other whaling images: 85/615.27, 85/615.34, 85/615.36. 


\section{Volume 11}

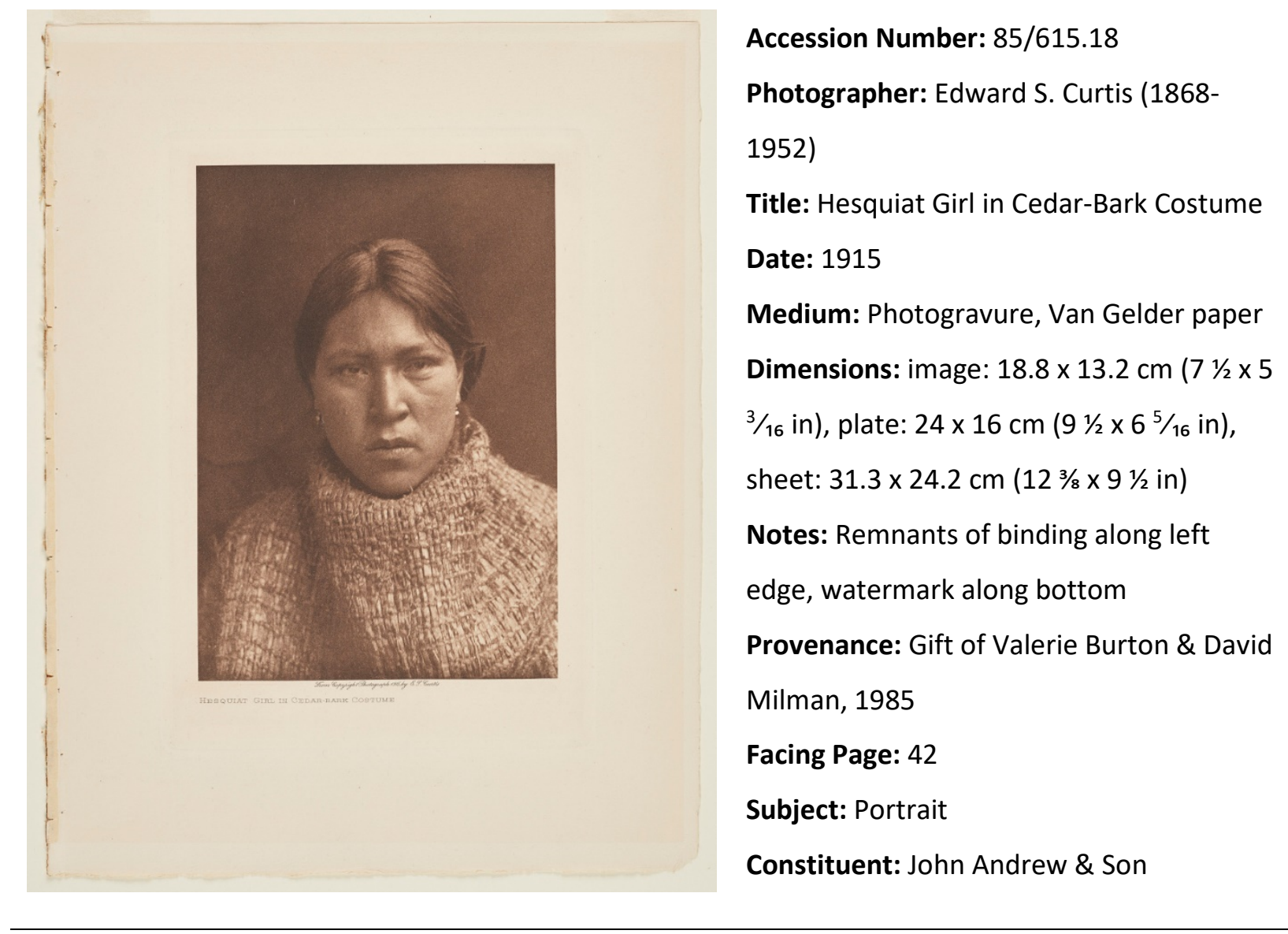

This image, along with the three following it, show Curtis's attempt at cultural typology. The images show the same person from the front and then in profile, like a mugshot. Sometimes they are unnamed as in the image above, but in some instances the name of the subject has been recorded as in "Súqitlaá" (85/615.1 \& 85/615.2). Within the NAl, fifty-five of the portraits carry a strictly typological framing: referring to a tribal type and sometimes followed by an image of the same subject in profile. ${ }^{1}$

Same subject as $85 / 615.21$.

\footnotetext{
${ }^{1}$ Shamoon Zamir, The Gift of the Face: Portraiture and Time in Edward S. Curtis's "The North American Indian" (Chapel Hill, NC: University of North Carolina Press), 2014.
} 


\section{Volume 11}

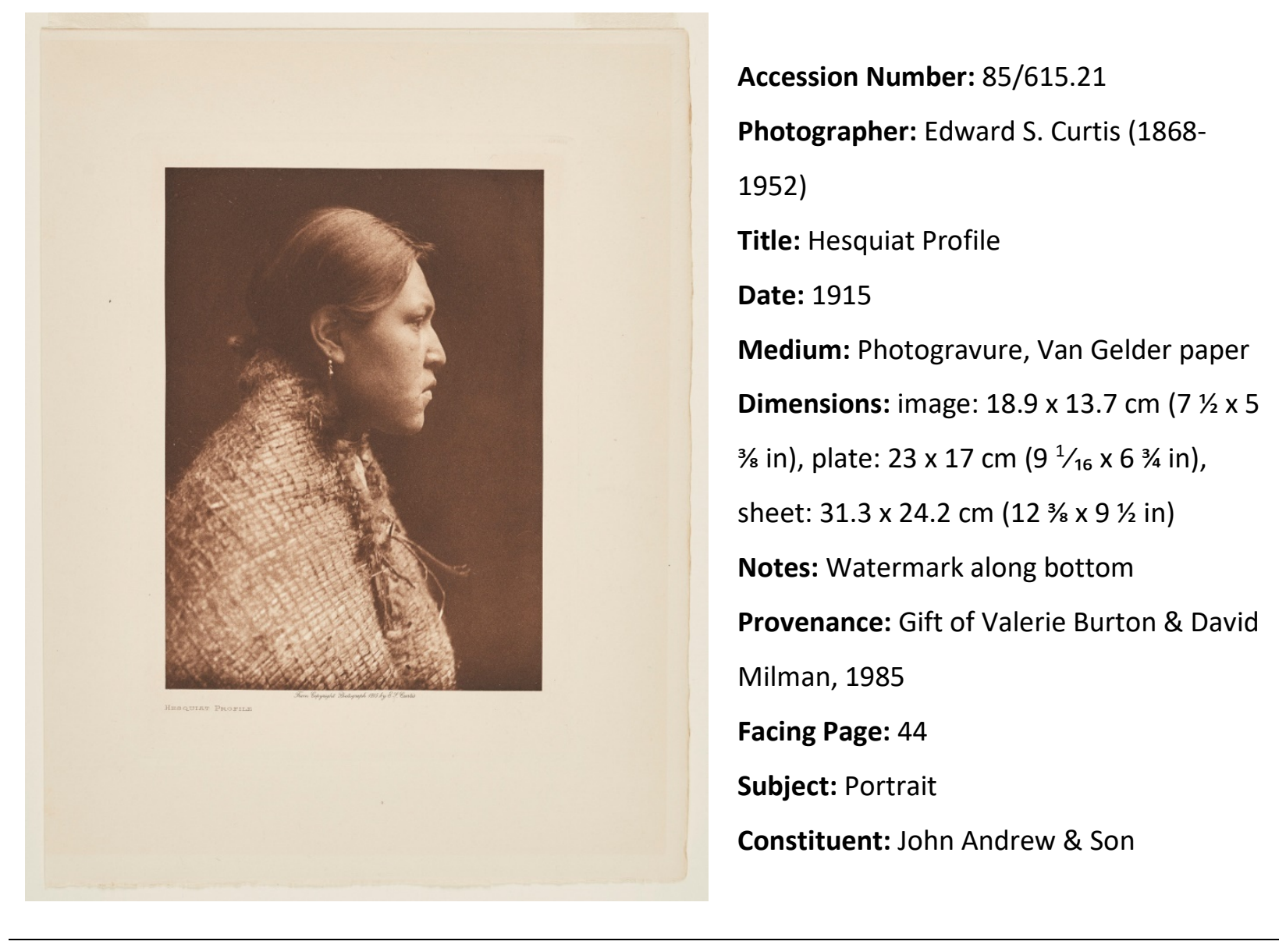

Same subject as 85/615.18. See 85/615.18. 


\section{Volume 11}

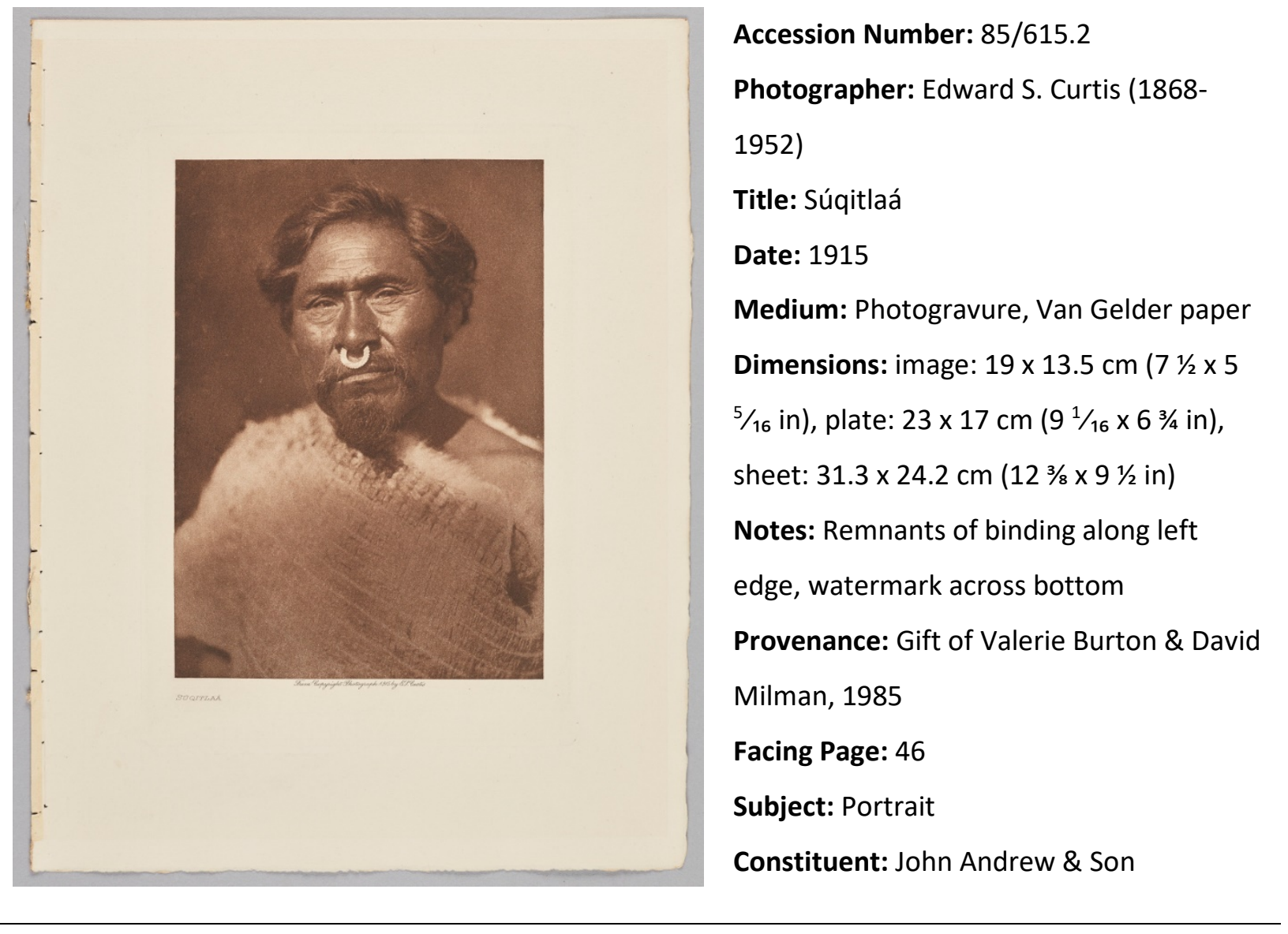

Same subject as 85/615.1. See 85/615.18. 


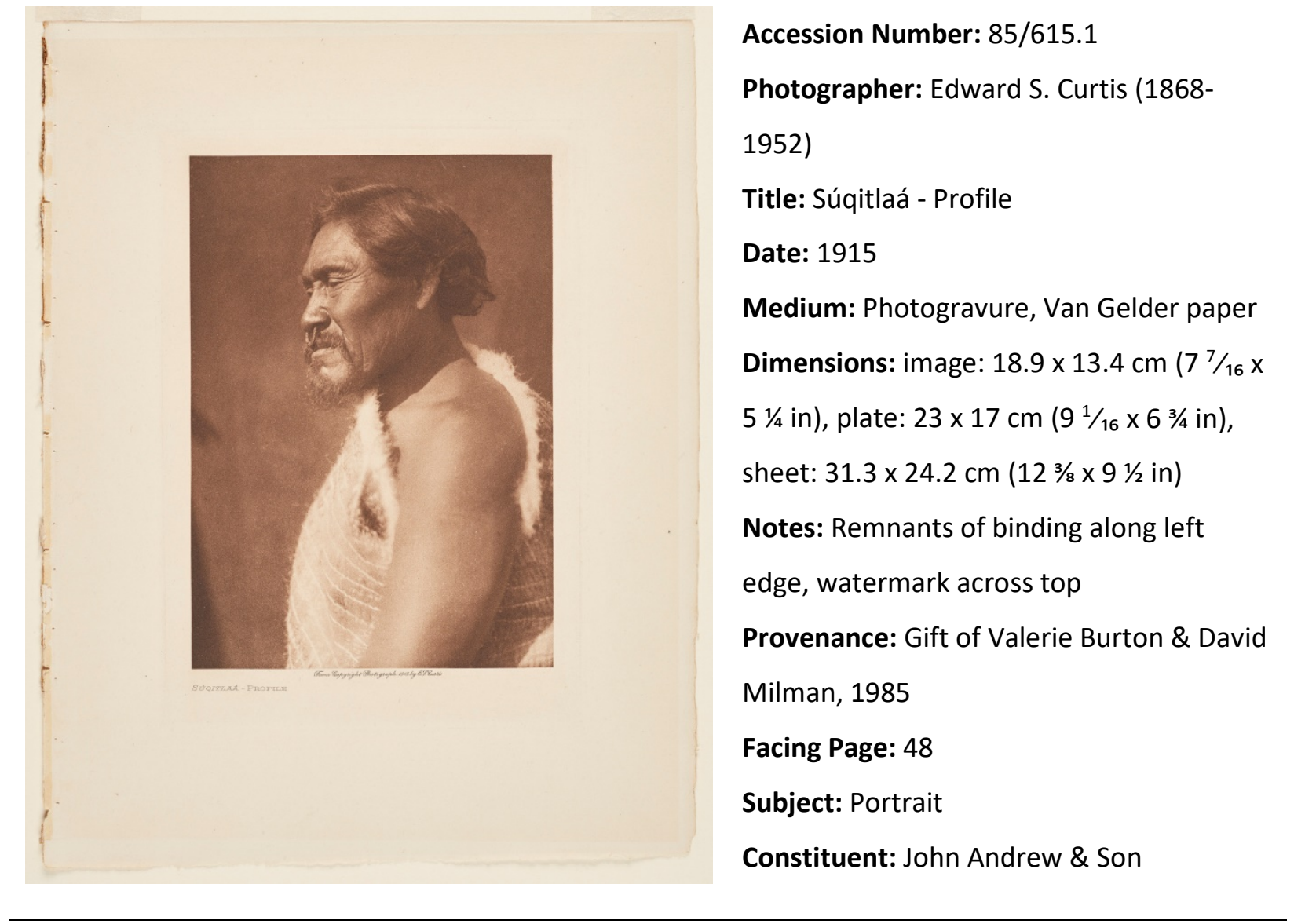

Same subject as 85/615.2. See 85/615.18. 


\section{Volume 11}

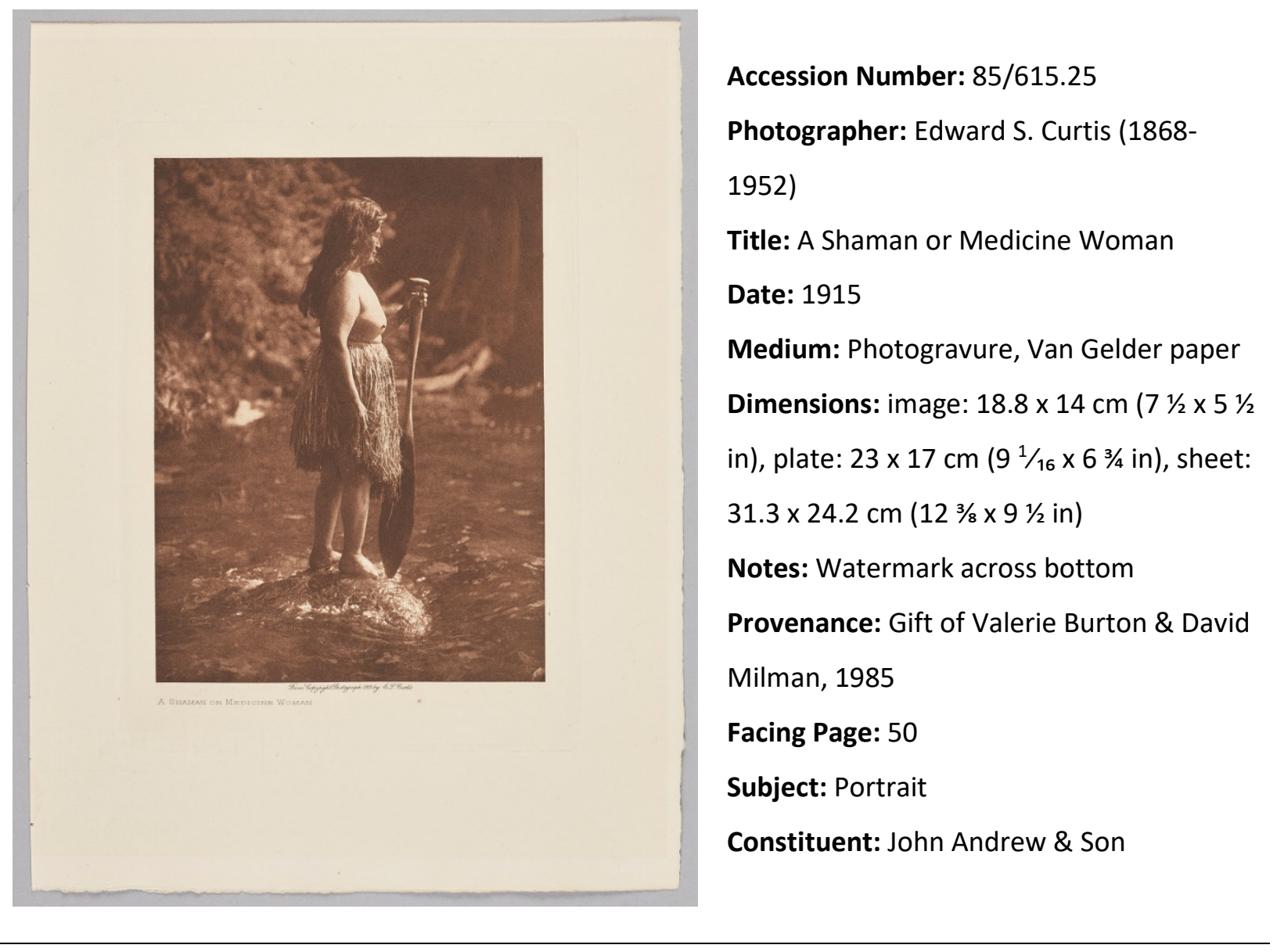

This composition is similar to "Ceremonial Preparation for Whaling" (85/615.27). Both show figures standing in cedar-bark skirts looking out over the water. They are both images of ceremony, showing that water is important to the culture and religion of the Nootka. 


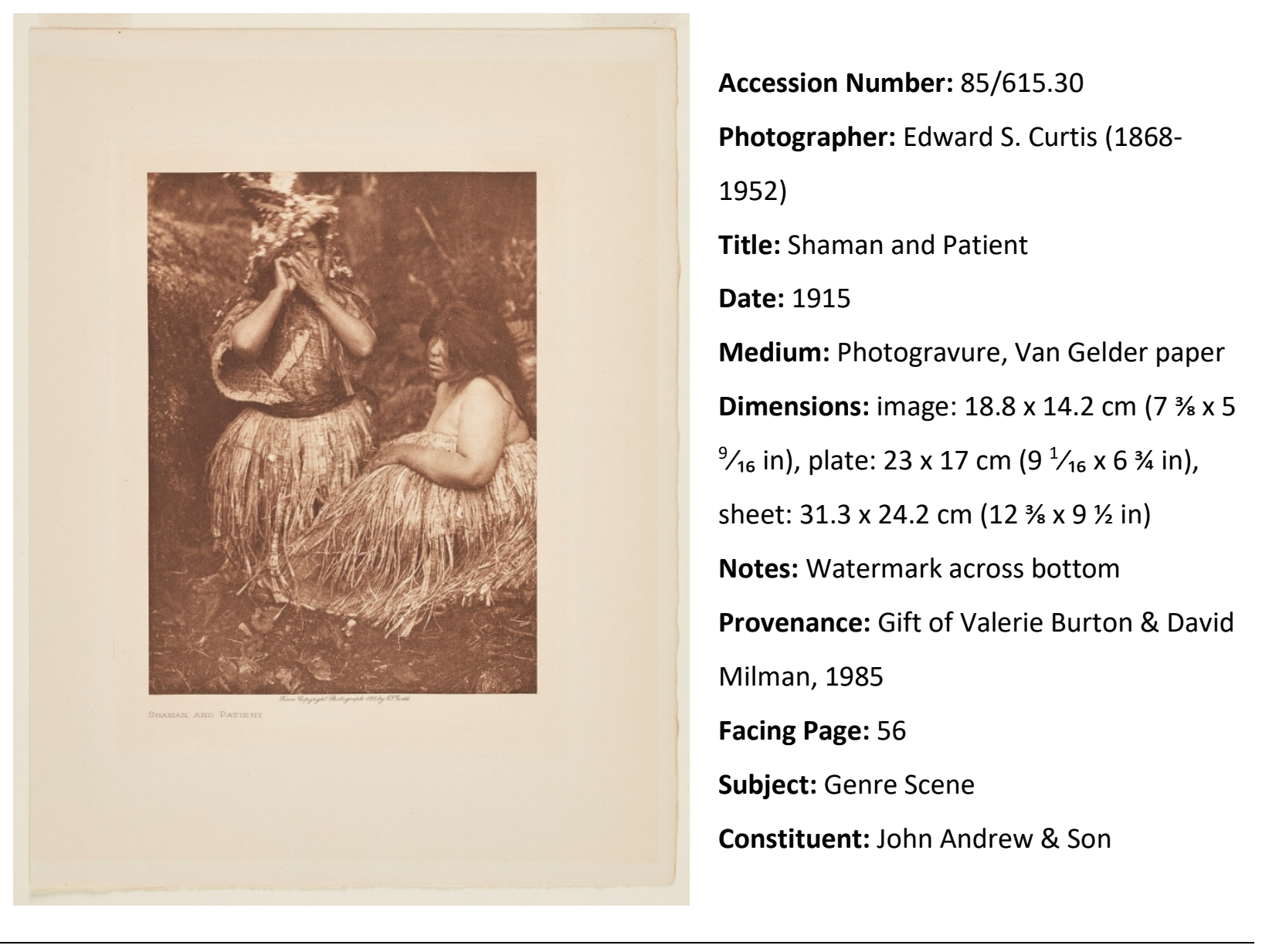




\section{Volume 11}

Accession Number: 85/615.35

Photographer: Edward S. Curtis (1868-

1952)

Title: Old Houses - Neah Bay

Date: 1915

Medium: Photogravure, Van Gelder paper

Dimensions: image: $13.8 \times 18.8 \mathrm{~cm} \mathrm{(5} \mathrm{1/2} \times 7$

$1 / 2$ in), plate: $18 \times 22 \mathrm{~cm}\left(71 / 16 \times 8 \frac{11 / 16}{\mathrm{in}}\right)$,

sheet: $24.2 \times 31.3 \mathrm{~cm}\left(9 \frac{1}{2} \times 12 \mathrm{3} / 8 \mathrm{in}\right)$

Notes: None

Provenance: Gift of Valerie Burton \& David

Milman, 1985

Facing Page: 60

Subject: Landscape

Constituent: John Andrew \& Son

Neah Bay is in Washington State on the Makah Reservation on the Olympic Peninsula. The Makah are a branch of the Nootka tribe. 


\section{Volume 11}

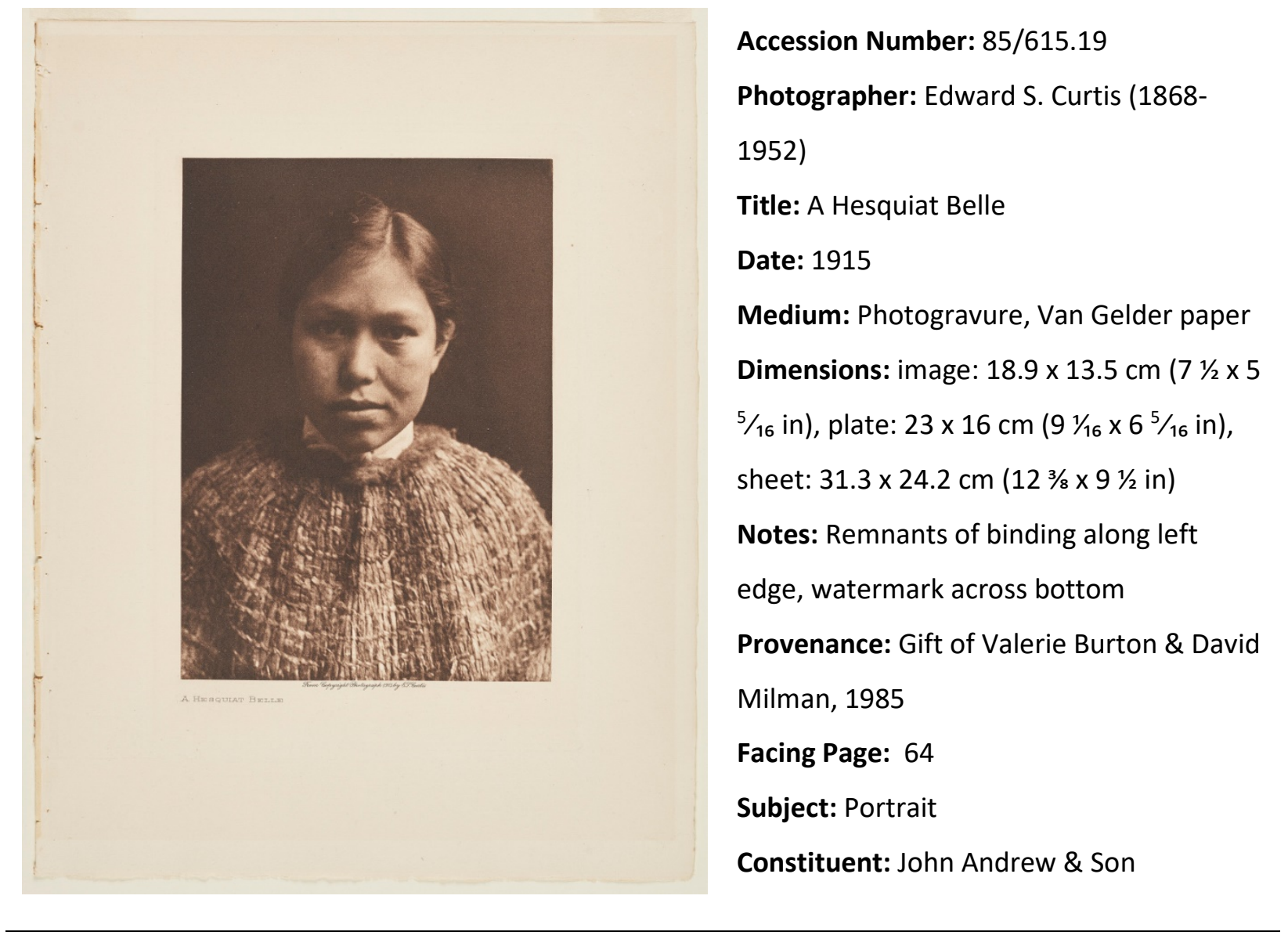

This girl wears the cedar-bark cape that protects the wearer from the rain. 


\section{Volume 11}

Accession Number: 85/615.47

Photographer: Edward S. Curtis (1868-

1952)

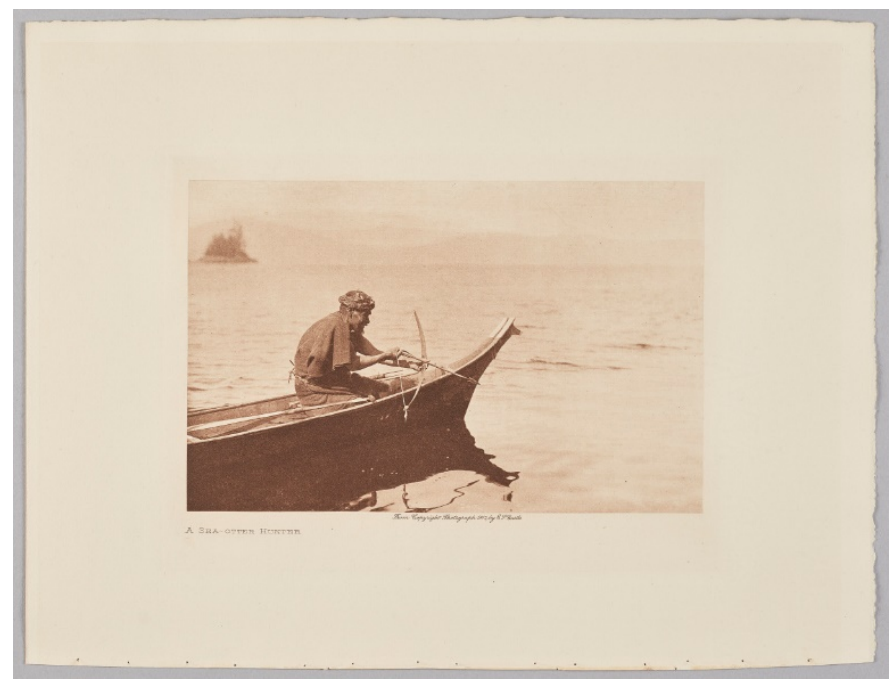

Title: A Sea-Otter Hunter

Date: 1915

Medium: Photogravure, Van Gelder paper

Dimensions: image: $12.1 \times 18.9 \mathrm{~cm} \mathrm{(4} \mathrm{3/4 \times 7}$

$1 / 2$ in), plate: $17 \times 22 \mathrm{~cm}\left(6^{11 / 16} \times 8^{11 / 16} \mathrm{in}\right)$, sheet: $24.2 \times 31.3 \mathrm{~cm}\left(9 \frac{1}{2} \times 12 \frac{3}{8}\right.$ in)

Notes: Remnants of binding along bottom edge

Provenance: Gift of Valerie Burton \& David Milman, 1985

Facing Page: 68

Subject: Genre Scene

Constituent: John Andrew \& Son

Later in life, Curtis wrote a book about sea otters. The book was never published but was based on the research he did for The North American Indian. It concentrated on Sea Otters along the coast from British Colombia to Alaska. 


\title{
Volume 11
}

Accession Number: 2006/345

Photographer: Edward S. Curtis (1868-

1952)

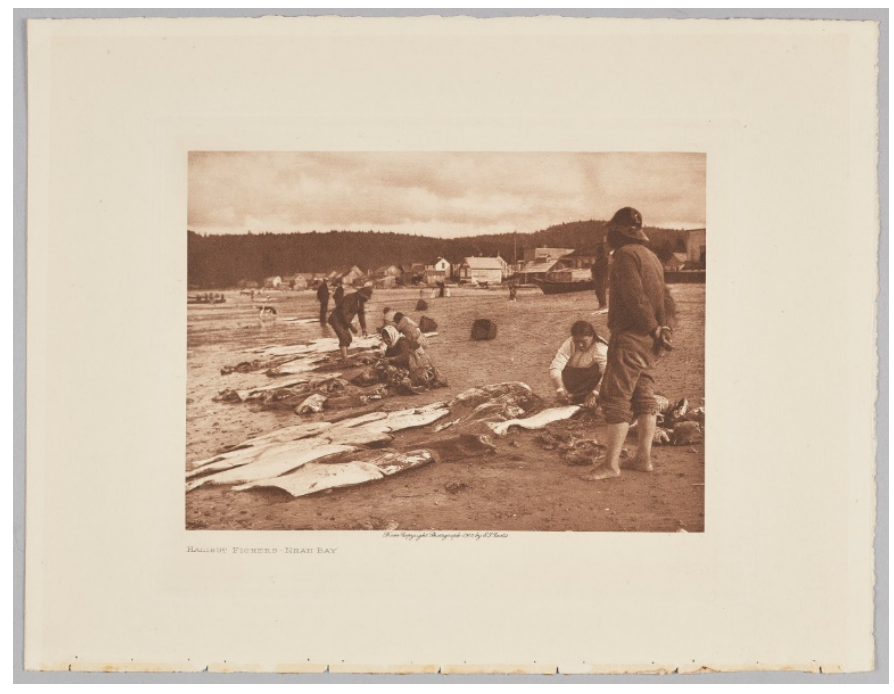

Title: Halibut Fishers - Neah Bay

Date: 1915

Medium: Photogravure, Van Gelder paper

Dimensions: image: 14 x $18.9 \mathrm{~cm}(5 \mathrm{1} / 2 \times 7$ 1 $1 / 2$

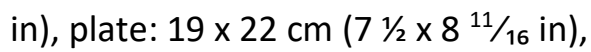

sheet: $24.2 \times 31.3 \mathrm{~cm}\left(9 \frac{1}{2} \times 12 \mathrm{3} / 8\right.$ in)

Notes: Remnants of binding along bottom

edge, watermark across left side

Provenance: Gift of John Richmond Harris,

2006

Facing Page: 76

Subject: Genre Scene

Constituent: John Andrew \& Son

\begin{abstract}
"Huge quantities of halibut are taken by the Makah at Cape Flattery, and the flesh is sliced thin and dried for storage." (NAI portfolio 11: caption for plate 393)
\end{abstract}

Neah Bay is known today as the best spot for halibut fishing in the continental United States. 


\section{Volume 11}

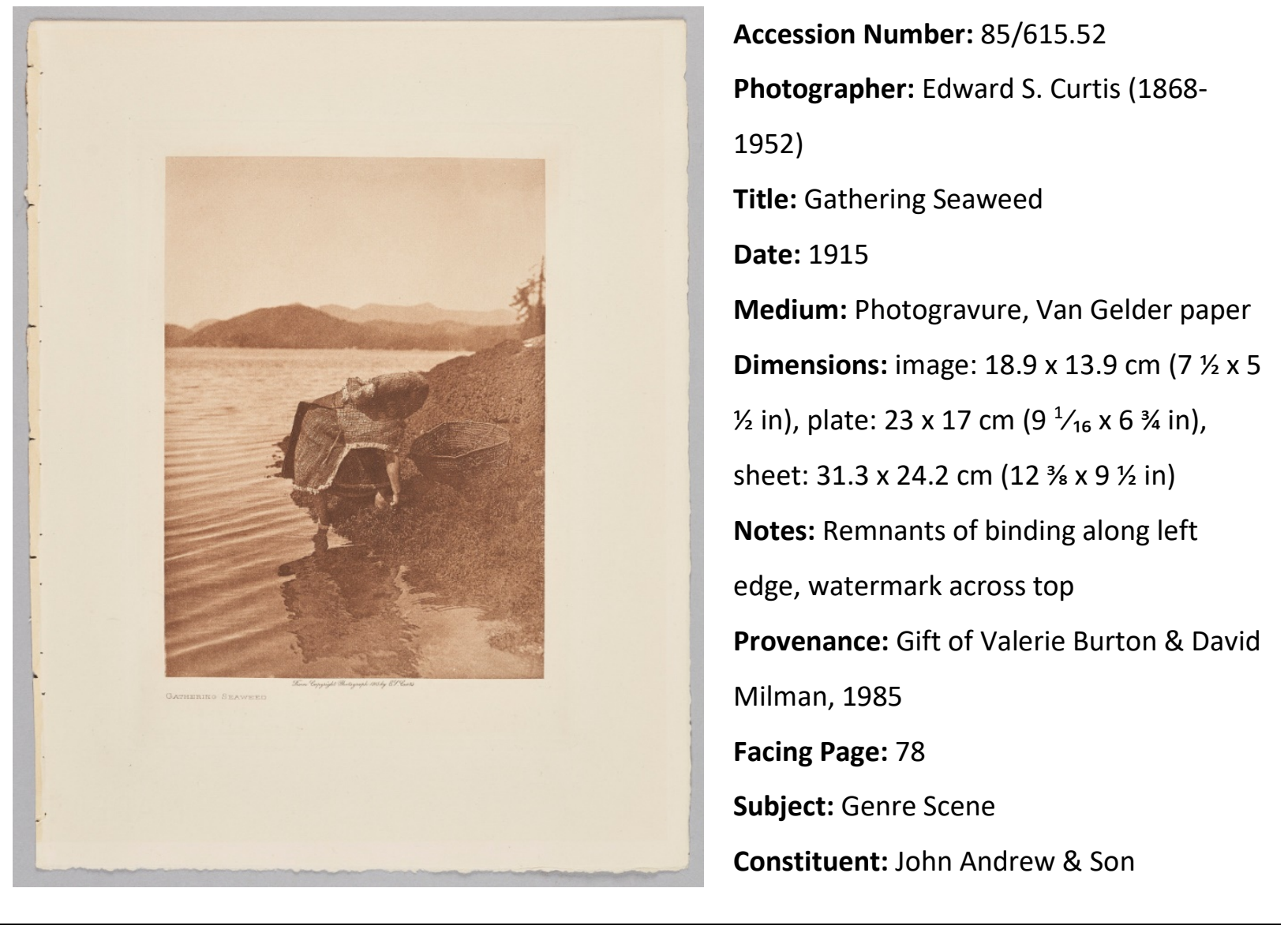

This is the first of two images titled "Gathering Seaweed" (See 85/615.46). Another Pictorialist, P.H. Emerson (British 1856-1936), took a photograph which he titled, "Gathering Waterlilies" (1886). From Curtis's writings, we know that he was familiar with the critical dialogue about photography (see Appendices D and E), and could have been familiar with Emerson's work. It is possible that Curtis was referencing Emerson with the title and composition of these two images. 


\section{Volume 11}

Accession Number: 85/615.43

Photographer: Edward S. Curtis (1868-

1952)

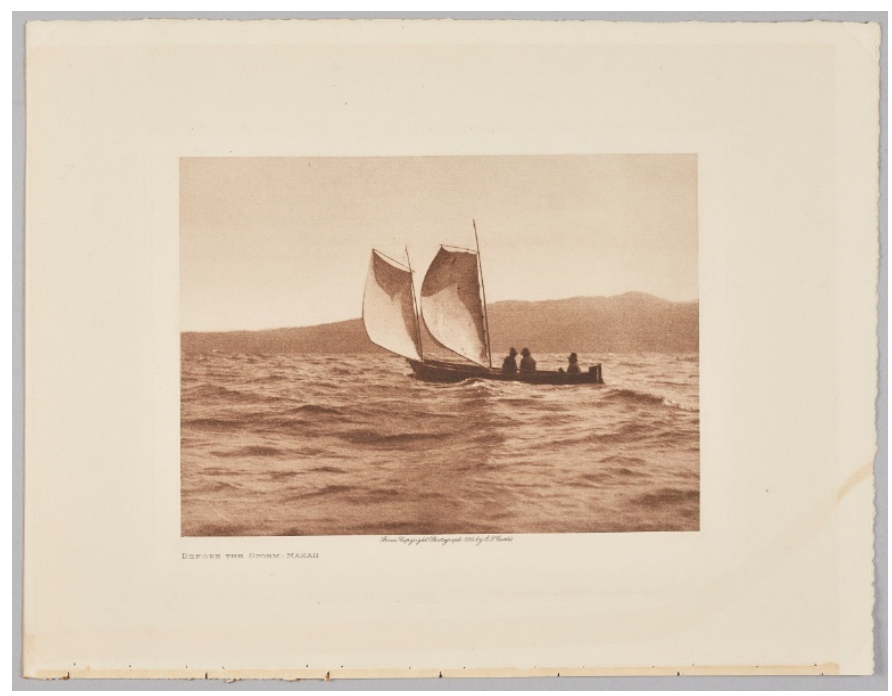

Title: Before the Storm - Makah

Date: 1915

Medium: Photogravure, Van Gelder paper

Dimensions: image: $13.8 \times 18.9 \mathrm{~cm} \mathrm{(5} \mathrm{1/2} \mathrm{x} 7$

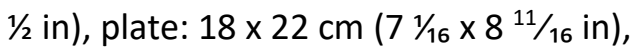

sheet: $24.2 \times 31.3 \mathrm{~cm}\left(9 \frac{1}{2} \times 12 \mathrm{3} / 8 \mathrm{in}\right)$

Notes: Remnants of binding along bottom

edge

Provenance: Gift of Valerie Burton \& David

Milman, 1985

Facing Page: 80

Subject: Genre Scene

Constituent: John Andrew \& Son

All three images of canoes in the AGO collection show the canoes silhouetted and from a distance.

Curtis likely positioned himself on the shore so that the horizon of the water was in the middle of the frame for each image. 


\section{Volume 11}

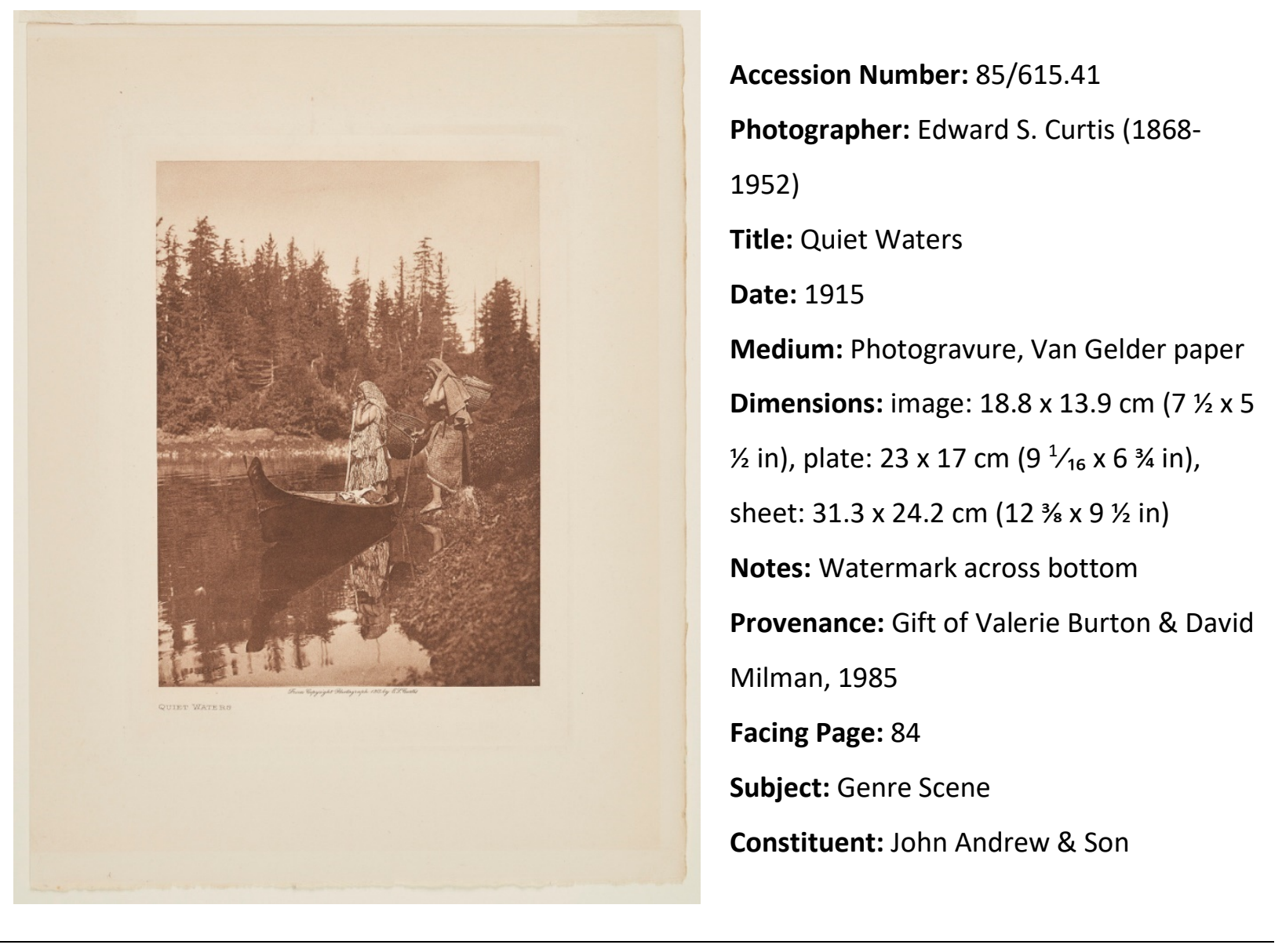

Curtis used the title "Quiet Waters" three times. One other print in the AGO collection shares the title (85/576). The third print that shares this name is found in portfolio 14, pl. 506 and depicts a man standing on a rock amidst a body of water. Curtis captures a mirror-like surface of the water in all of three images. In Plate 506, the figure is in the foreground of the image making him more recognizable, which stands in contrast with the figures that are unrecognizable in the other two images. All the images emphasize the land in relation to the figures showing an interdependence between land and people. 


\section{Volume 11}

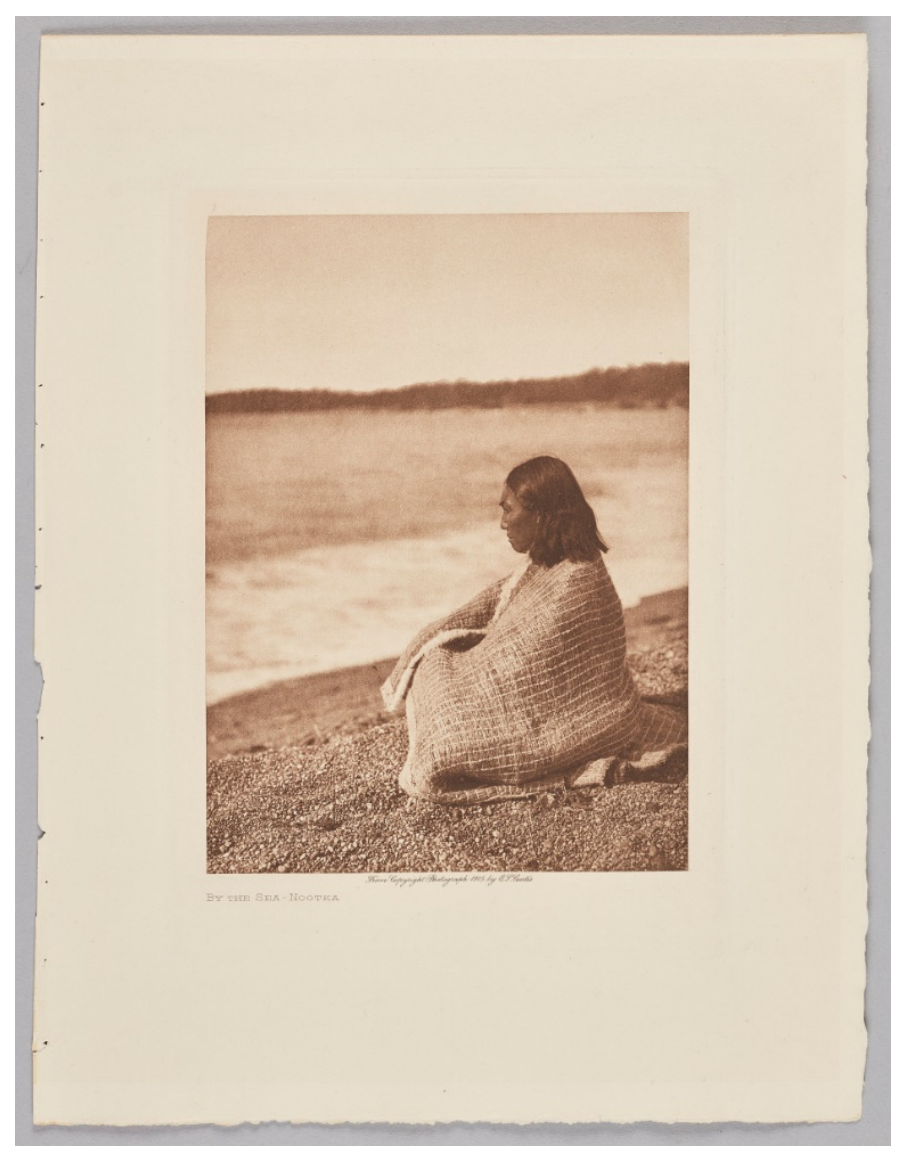

Accession Number: 85/615.23

Photographer: Edward S. Curtis (1868-

1952)

Title: By the Sea - Nootka

Date: 1915

Medium: Photogravure, Van Gelder paper

Dimensions: image: $18.8 \times 13.9 \mathrm{~cm}\left(7 \frac{1}{2} \times 5\right.$

$1 / 2$ in), plate: $23 \times 17 \mathrm{~cm}\left(9 \frac{1}{16} \times 63 / 4 \mathrm{in}\right)$,

sheet: $31.3 \times 24.2 \mathrm{~cm}(123 / 8 \times 91 / 2$ in)

Notes: Remnants of binding along left edge

Provenance: Gift of Valerie Burton \& David

Milman, 1985

Facing Page: 86

Subject: Genre Scene

Constituent: John Andrew \& Son

Possibly same subject as 85/615.17 and plate 366 . 


\section{Volume 11}



Curtis does not make a direct reference to this image, but does describe the use of hemlock in ceremonies, including in preparation for whale hunting. Before hunting, whalers would wash themselves, rub hemlock on their bodies, and tie a crown of hemlock leaves about their head. 


\section{Volume 11}

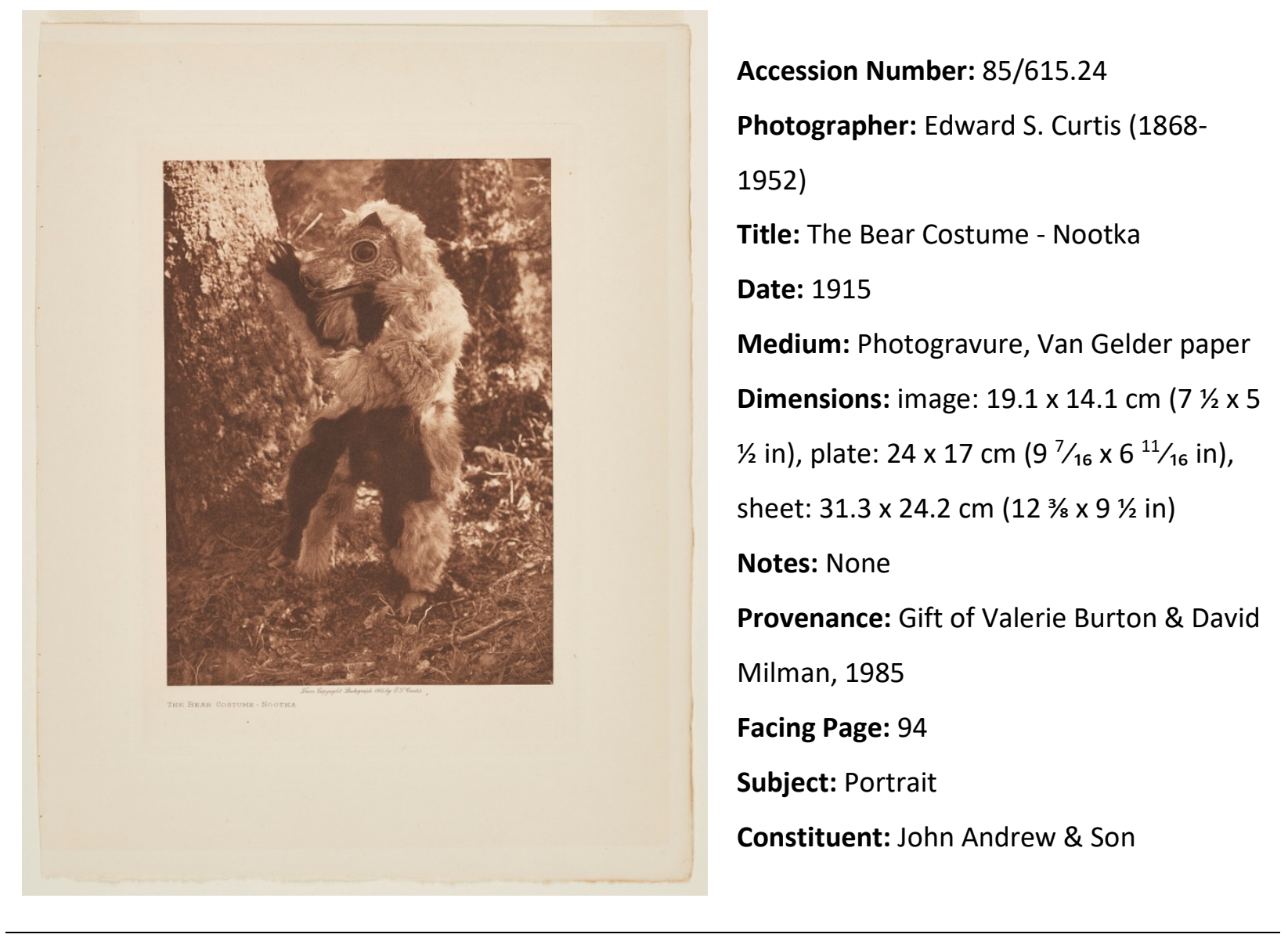

Nŭnŭkén“k ("grizzly-bear personator")

According to the index of Volume 11, this costume belongs to the Kyuquot secret society in which there are eight kinds of dancers: núhlĭm, the deer dancer; úshtakiyá, a dancer for good in contrast to háme'ts; qoíyitsín`k, "wolf personator;" nŭnŭkén`k, "grizzly-bear personator;" wínachtin`k, the war dancer; wúhnaken'k, "otter personator;" haiyáhlĭn, a white spirit seen in the forest; háme'ts, the hamatsa. Curtis does not elaborate on the individual roles of the dancers or what kinds of ceremonies they are involved with. 


\section{Volume 11}

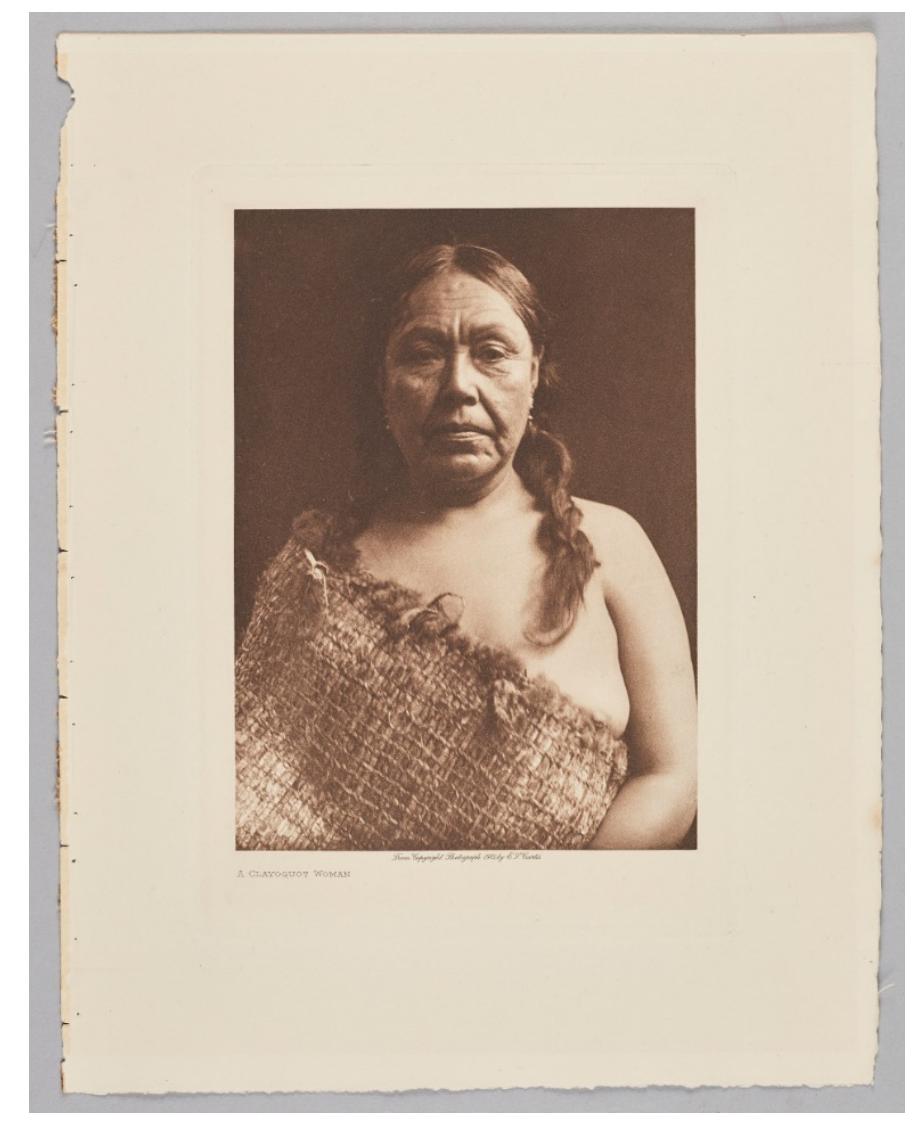

Accession Number: 85/615.16

Photographer: Edward S. Curtis (18681952)

Title: A Clayoquot Woman

Date: 1915

Medium: Photogravure, Van Gelder paper

Dimensions: image: $18.8 \times 13.6 \mathrm{~cm}(73 / 8 \times 5$ $3 / 8$ in), plate: $23 \times 17 \mathrm{~cm}\left(9 \frac{1}{16} \times 6 \frac{3}{4} \mathrm{in}\right)$, sheet: $31.3 \times 24.2 \mathrm{~cm}\left(123 / 8 \times 9 \frac{1}{2} \mathrm{in}\right)$ Notes: Remnants of binding along left edge Provenance: Gift of Valerie Burton \& David Milman, 1985

Facing Page: 96

Subject: Portrait

Constituent: John Andrew \& Son

"Both sexes wore cedar-bark or fur robes pinned together at the right side, and women had in addition bark aprons extending from waist to knees. In rainy weather bark capes like a poncho were worn. Both sexes used hats in rain and hot sunshine, those of the common people being woven bark and those of the nobility, spruce-roots. Men wore the hair loose or twisted in a knot; women had it in two braids down the back." (NAI volume 11: page 178) 


\section{Volume 11}

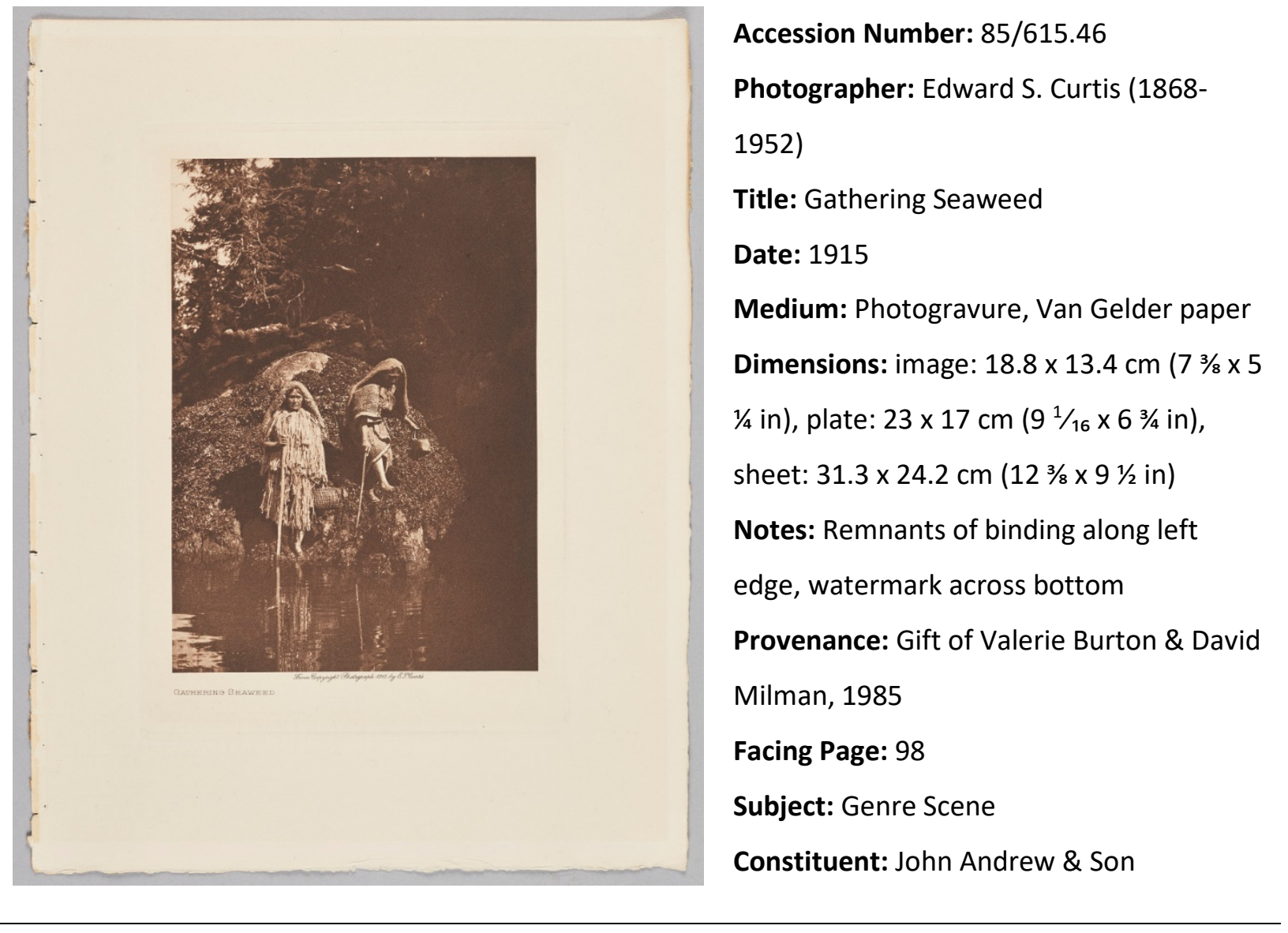

This is the second of two images in this volume titled "Gathering Seaweed." See 85/615.52.

Seaweed was one of the principal foods eaten by the Nootka and the Haida. Both tribes had a diet relying heavily on fish or whale, roots, and berries.

"Seaweed of the genus Porphyra is a favourite food among all the tribes of the North Pacific coast. The green, membranous fronds are gathered in the spring from tidal rocks and are pressed into flat cakes and dried." (NAI portfolio 11: caption for plate 369) 


\section{Volume 11}

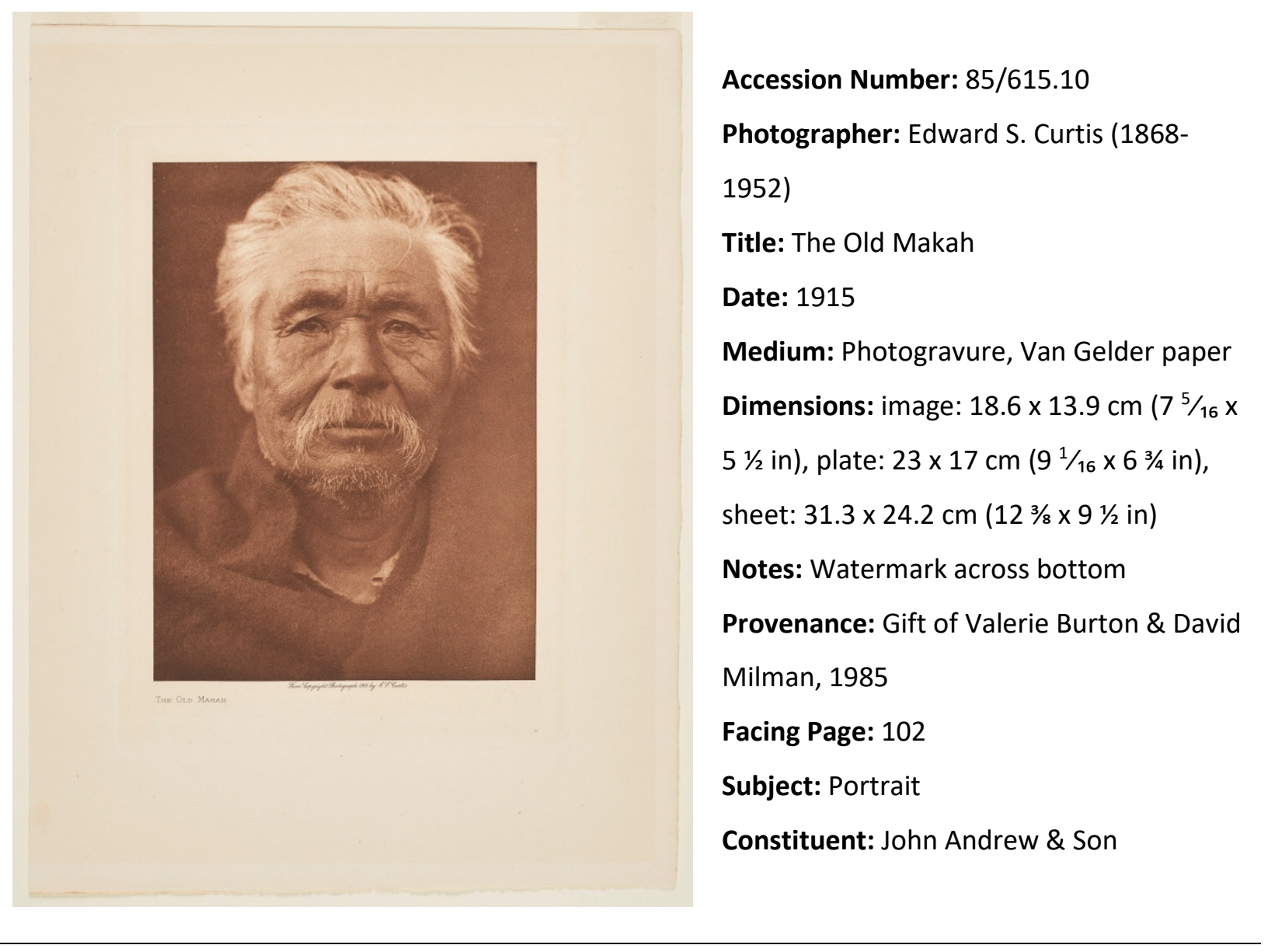

Near the end of a volume, there is sometimes a succession of portraits. Some are typological with front and side views of the same subject, but the majority are not.

Blankets are draped around many of the subjects, presumably to hide modern clothing. This felt type blanket appears in several images: 85/615.3, 85/615.7, 85/615.11, 85/615.12, 85/615.22, 85/615.29, $85 / 615.49,85 / 615.50$.

Same subject as 85/615.3. See 85/615.18. 


\section{Volume 11}

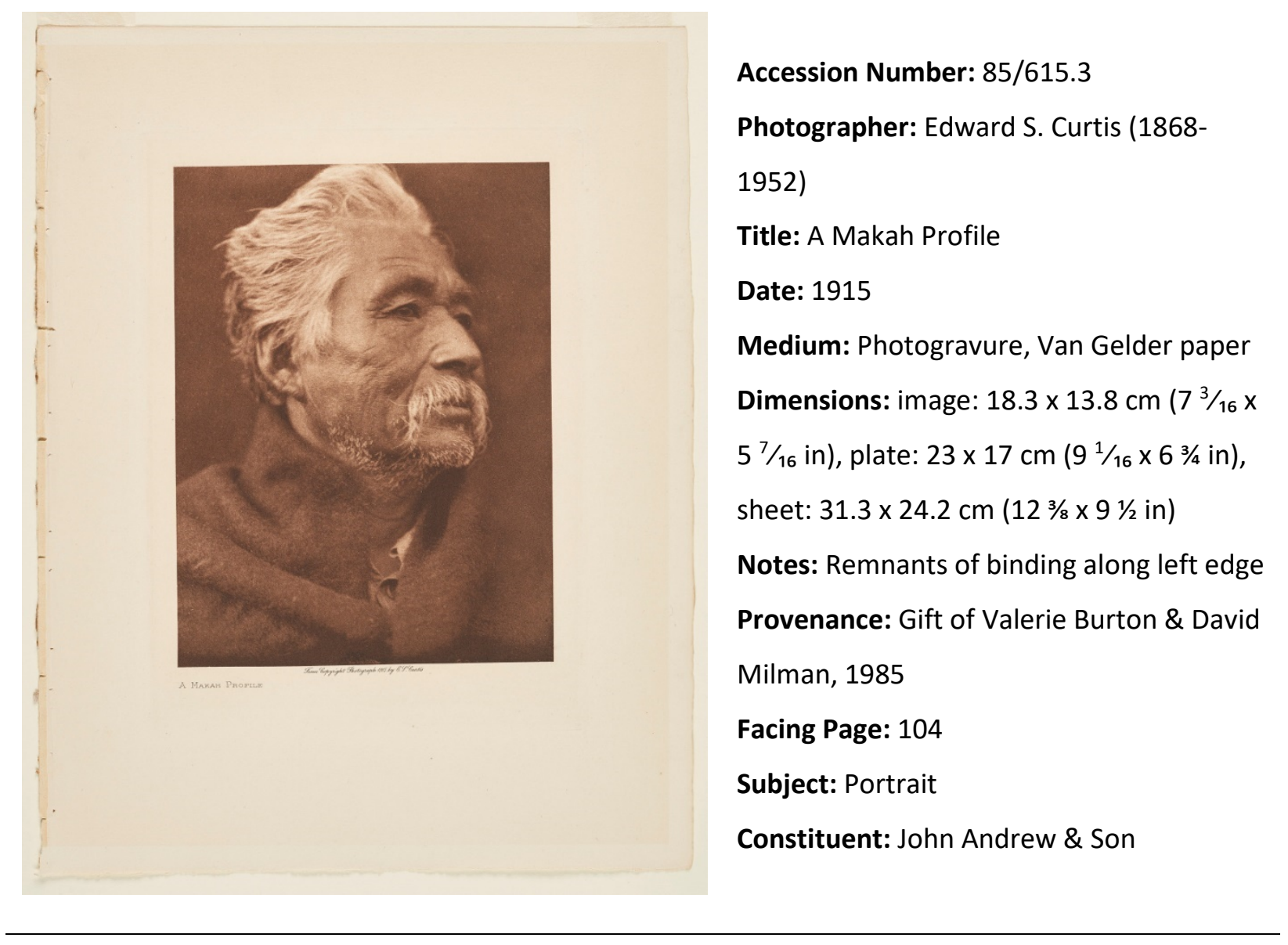

Same subject as 85/615.10. See 85/615.18. 


\section{Volume 11}

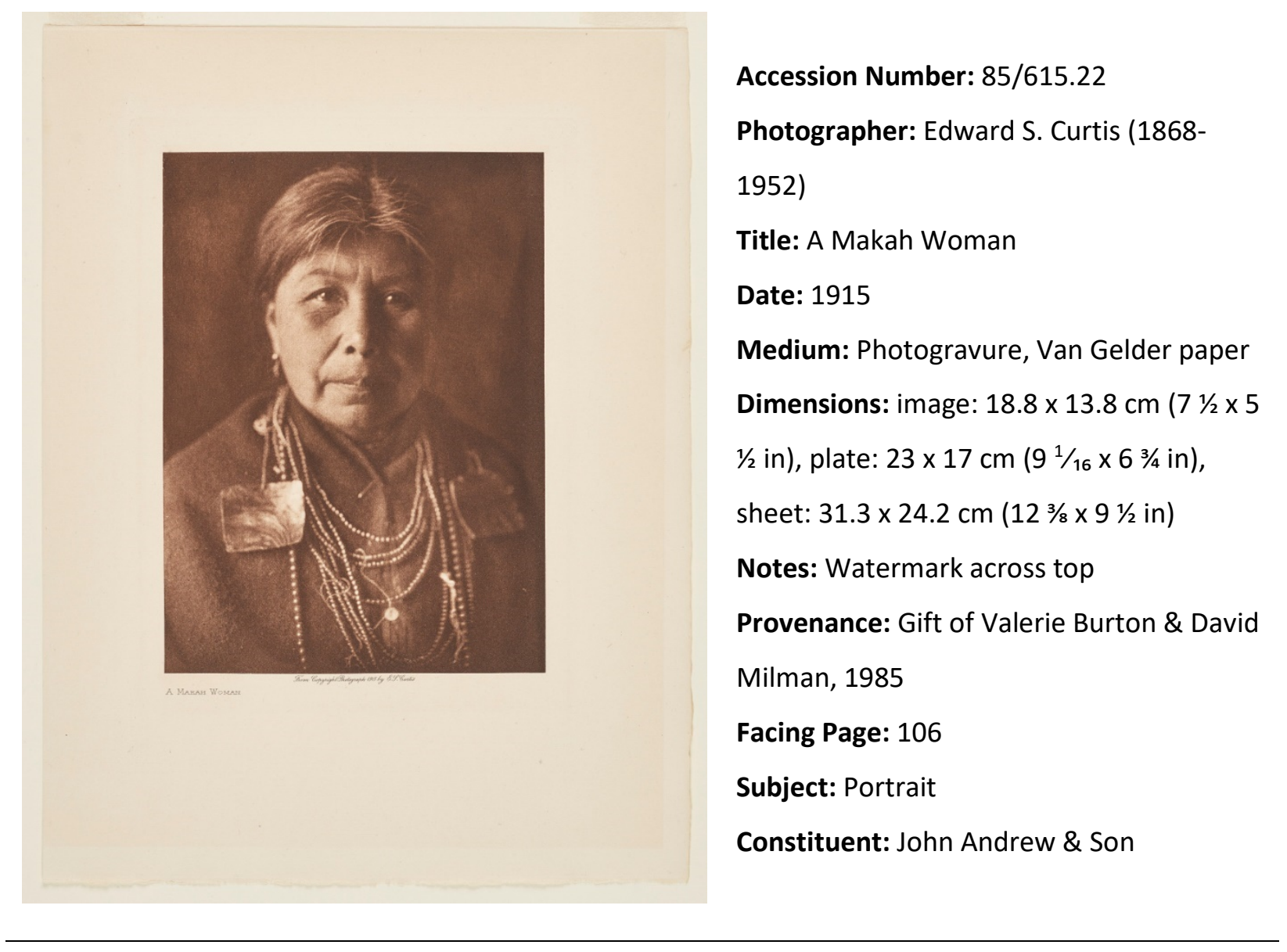

"Ornaments for men and women of high rank were abalone-shell nose-rings, and dentalium shells suspended from the ears (or from the braided hair of women). Women also used bracelets woven from the long, white fibres of bracken roots, and tight anklets of deerskin, which were intended to keep the ankles slender." (NAI volume 11: page 11)

The woman in this image appears to be wearing a necklace made with abalone-shell. 


\section{Volume 11}

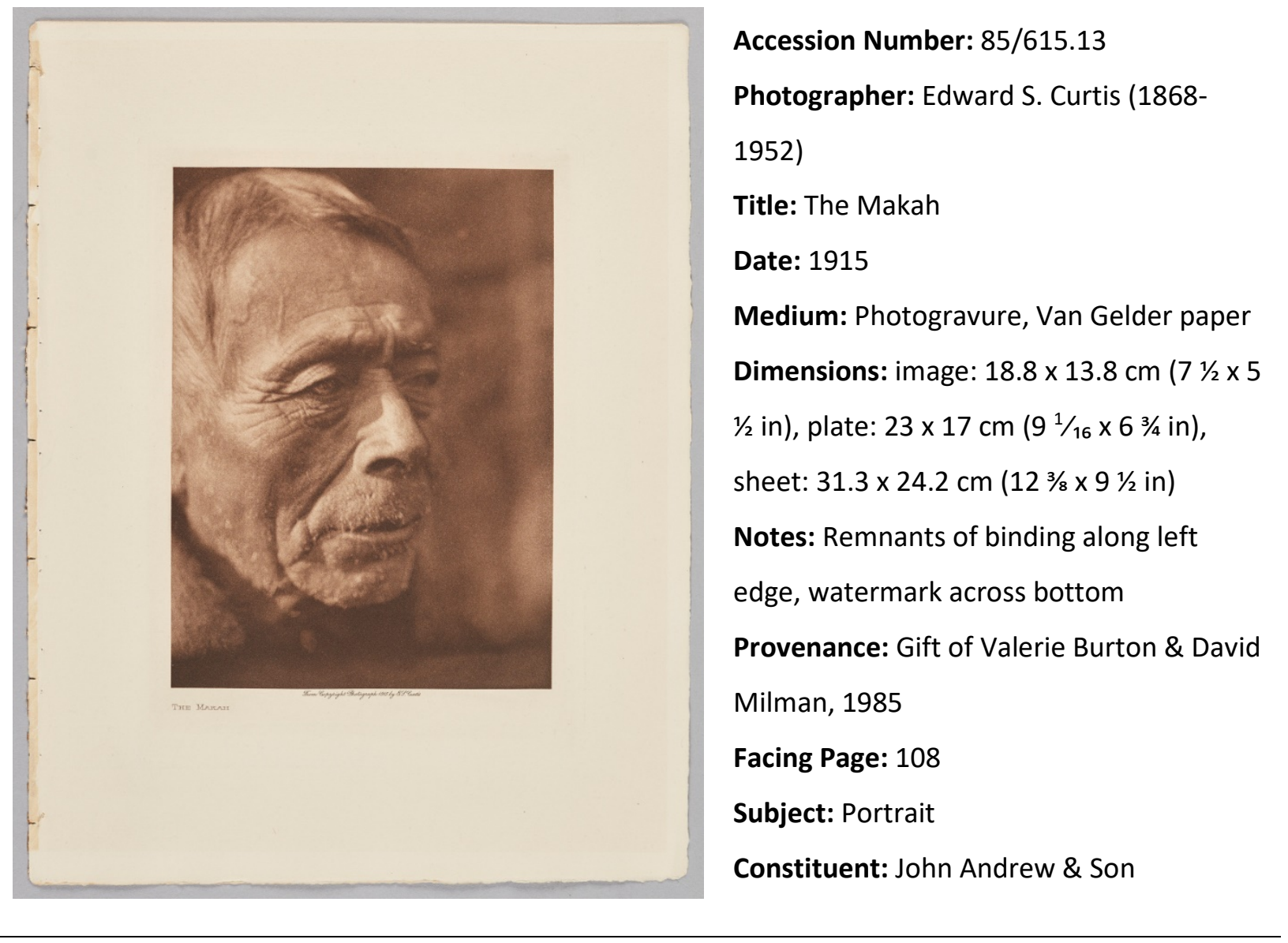

This image is curiously titled, "The Makah." Makah is the name of the Nootka tribes residing on the Olympic Peninsula in Washington State. Perhaps Curtis saw this elder of the tribe as representative of the Makah "type" or he was a well-respected man or Chief. 


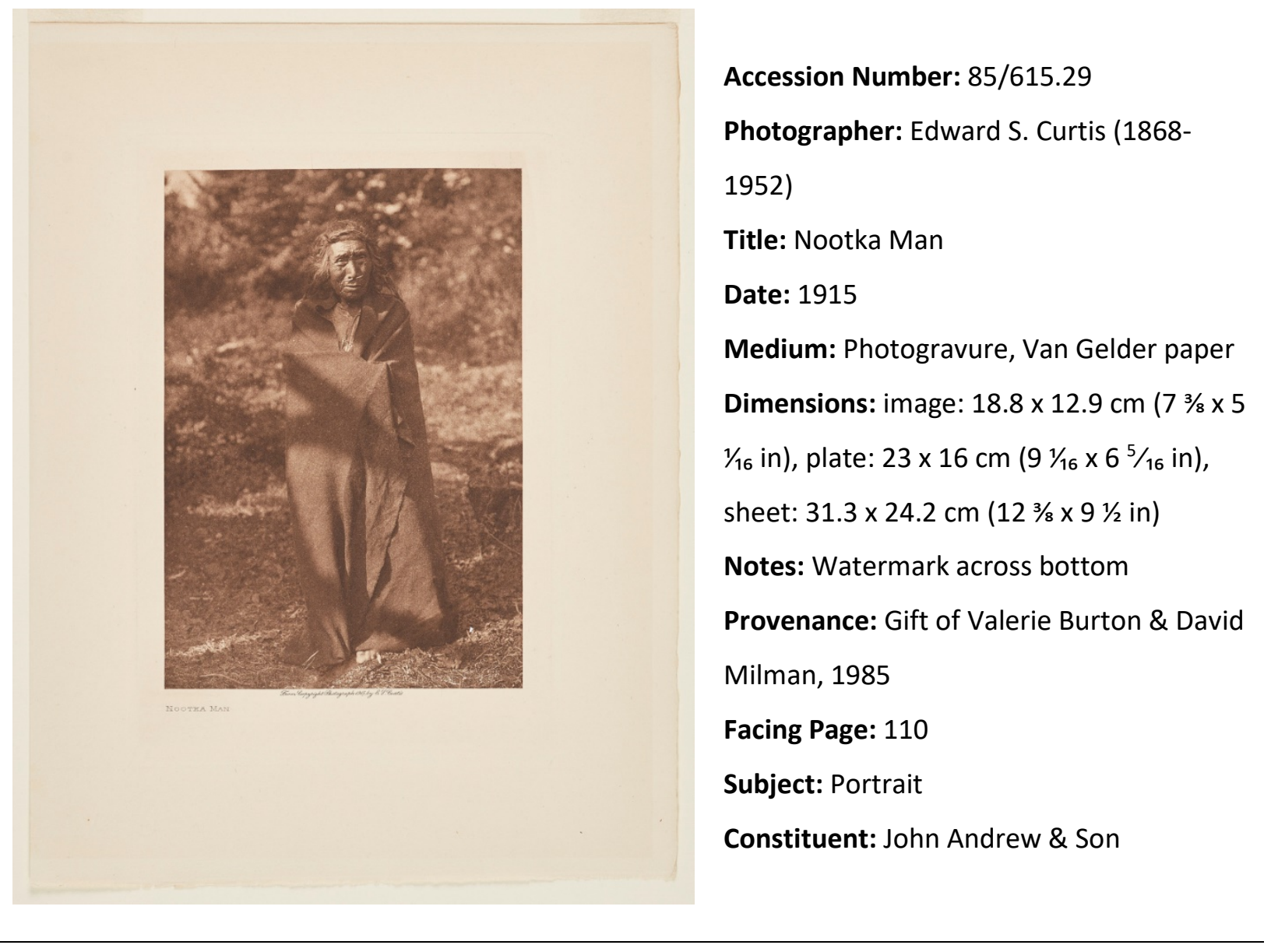

See 85/615.10. 


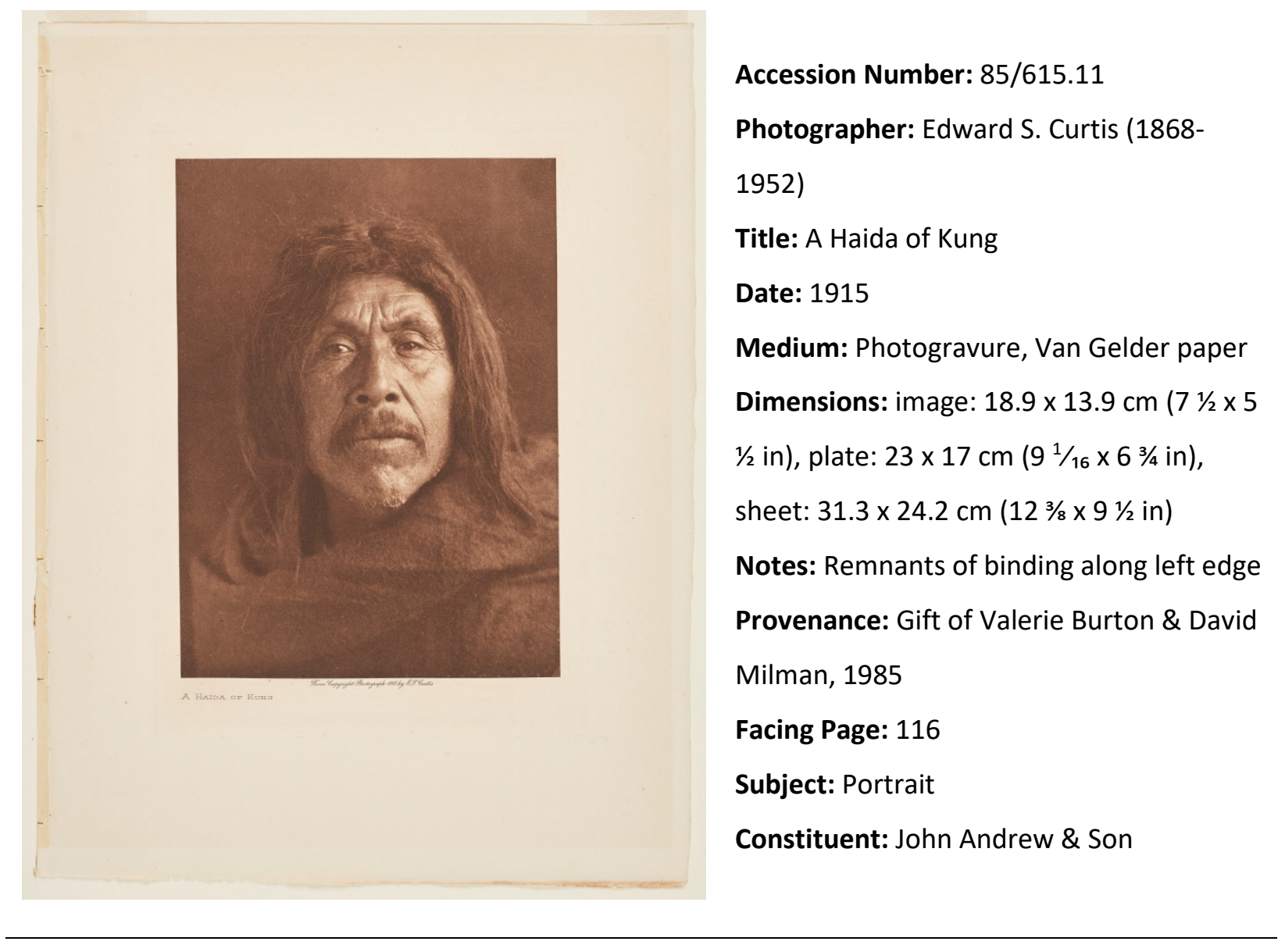

See 85/615.10. 


\section{Volume 11}

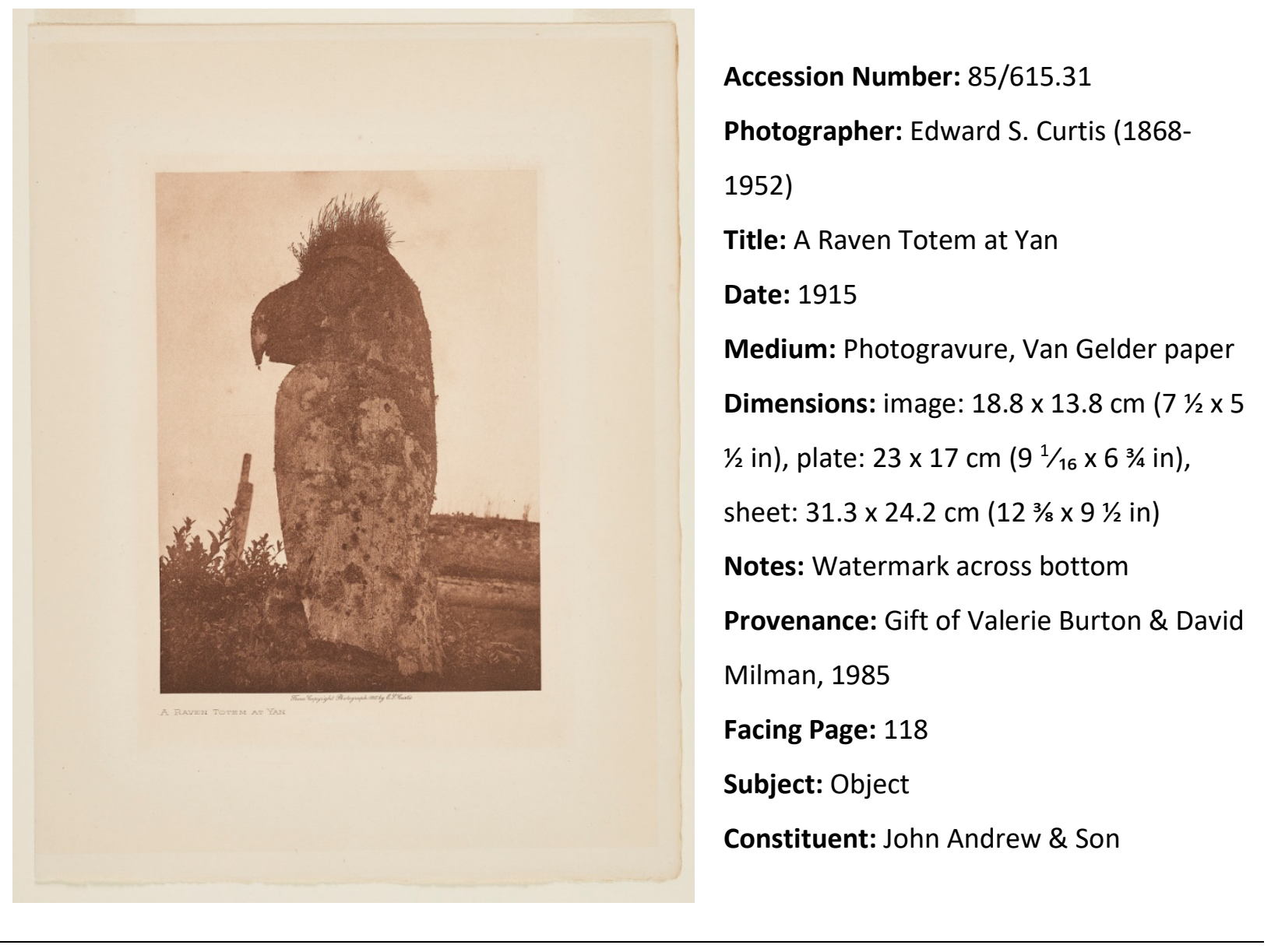

The Haida have two clans: the Raven and the Eagle. This Raven totem is a crest displayed outside a family's home. 


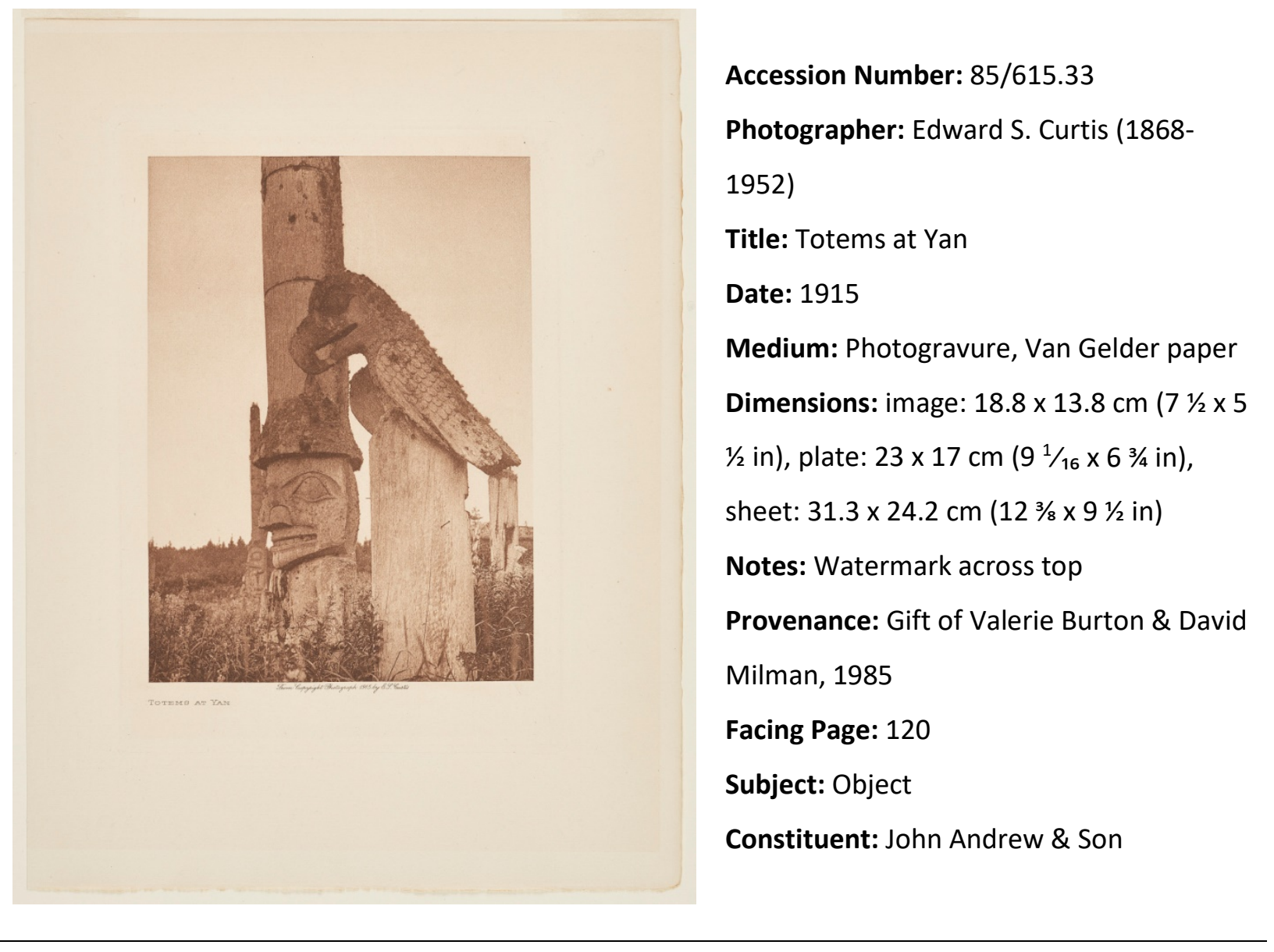




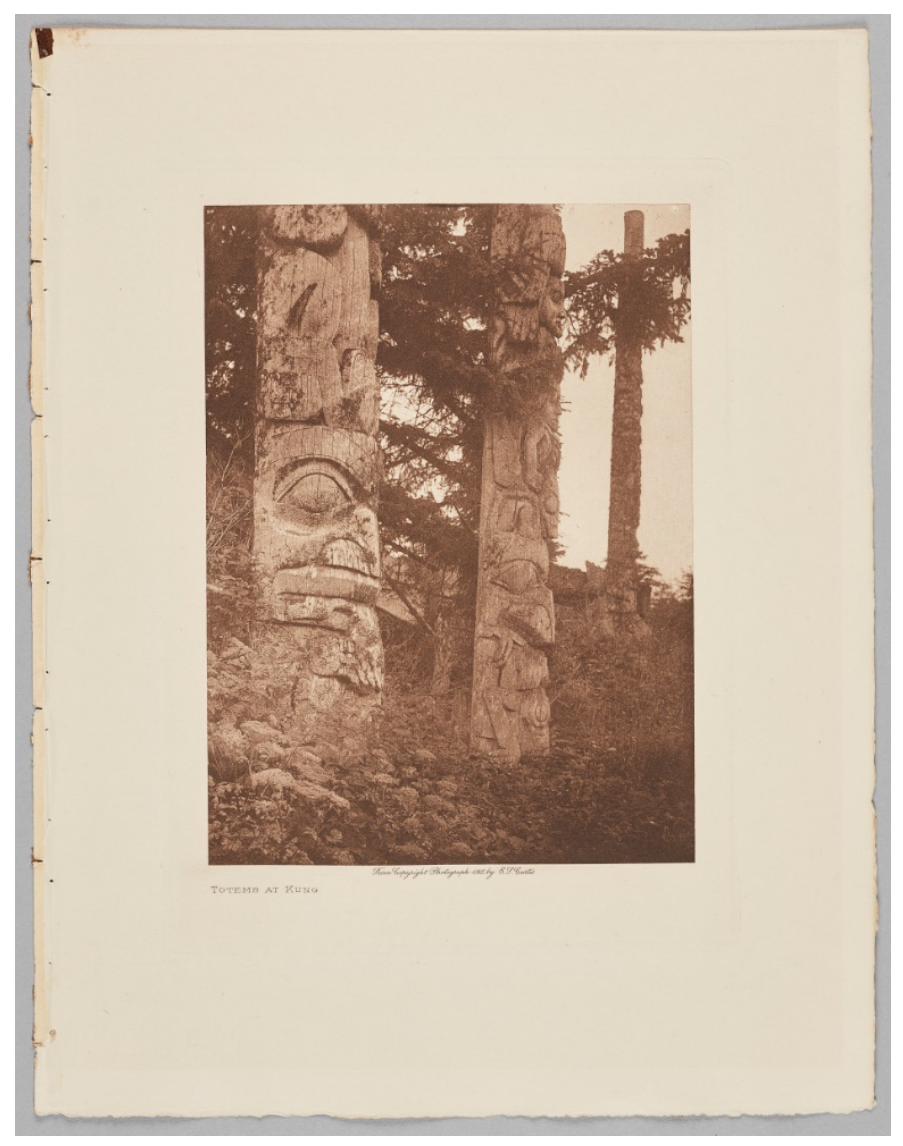

Accession Number: 85/615.32

Photographer: Edward S. Curtis (1868-

1952)

Title: Totems at Kung

Date: 1915

Medium: Photogravure, Van Gelder paper

Dimensions: image: $18.8 \times 14 \mathrm{~cm}\left(7 \frac{1}{2} \times 5\right.$ 1/2 in), plate: $23 \times 17 \mathrm{~cm}\left(9 \frac{1}{16} \times 6 \frac{3}{4} \mathrm{in}\right)$, sheet: $31.3 \times 24.2 \mathrm{~cm}\left(12 \frac{3}{8} \times 9 \frac{1}{2} \mathrm{in}\right)$

Notes: Remnants of binding along left edge

Provenance: Gift of Valerie Burton \& David Milman, 1985

Facing Page: 122

Subject: Object

Constituent: John Andrew \& Son 


\section{Volume 11}

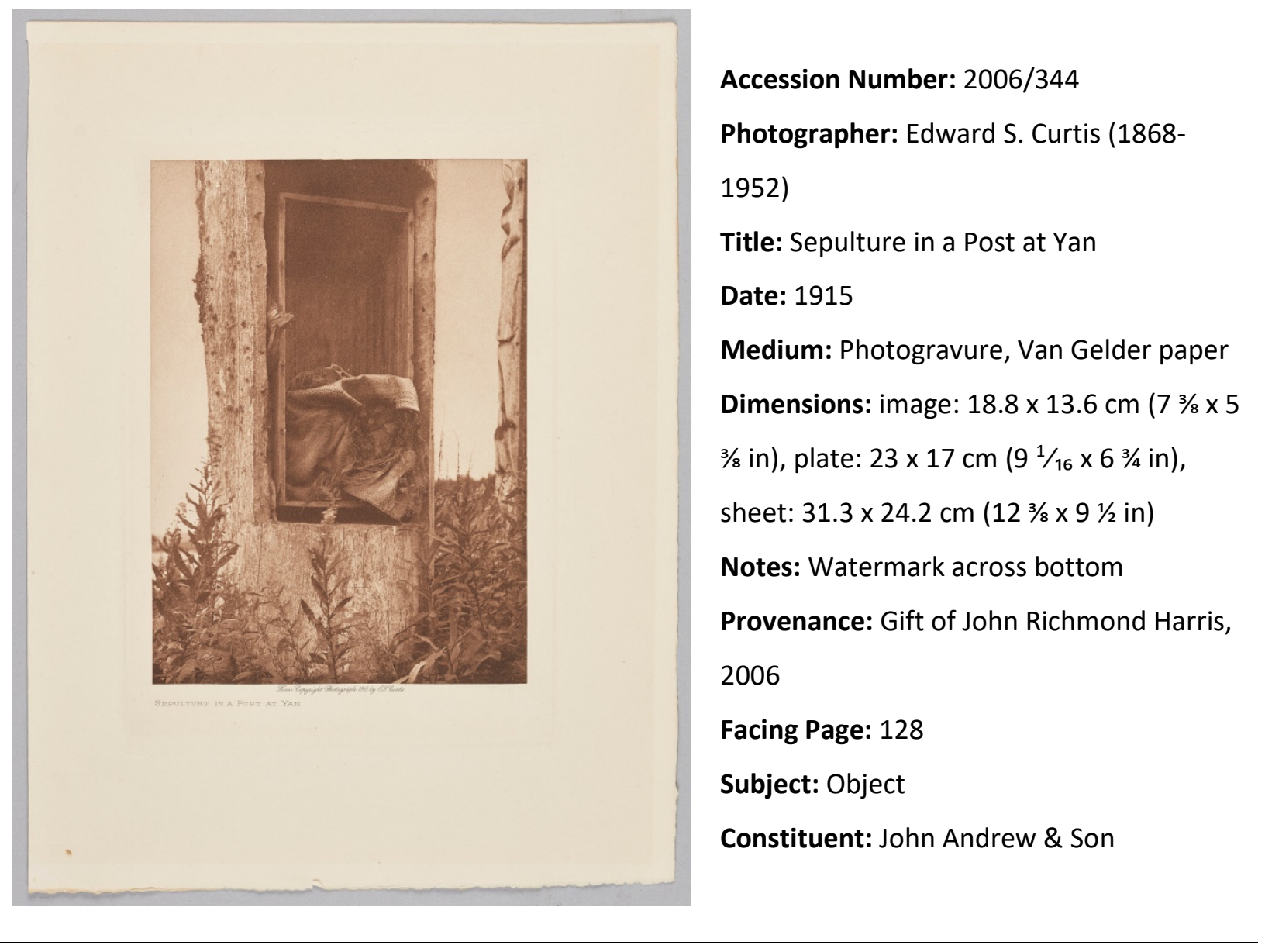

This image depicts the interment of a coffin in a post. According to custom, after a period of time had passed (length unknown), the coffin was placed in a niche at the top or bottom of a mortuary post erected by their successor and burned. Relatives would throw food and water into the flames so the spiritual counterpart of the substance would pass to the dead. See NAI Volume 11, page 187.

Curtis included as many aspects of the cultures he was studying, which included what he referred to as mortuary customs. 


\section{Volume 11}

Accession Number: 85/615.42

Photographer: Edward S. Curtis (1868-

1952)

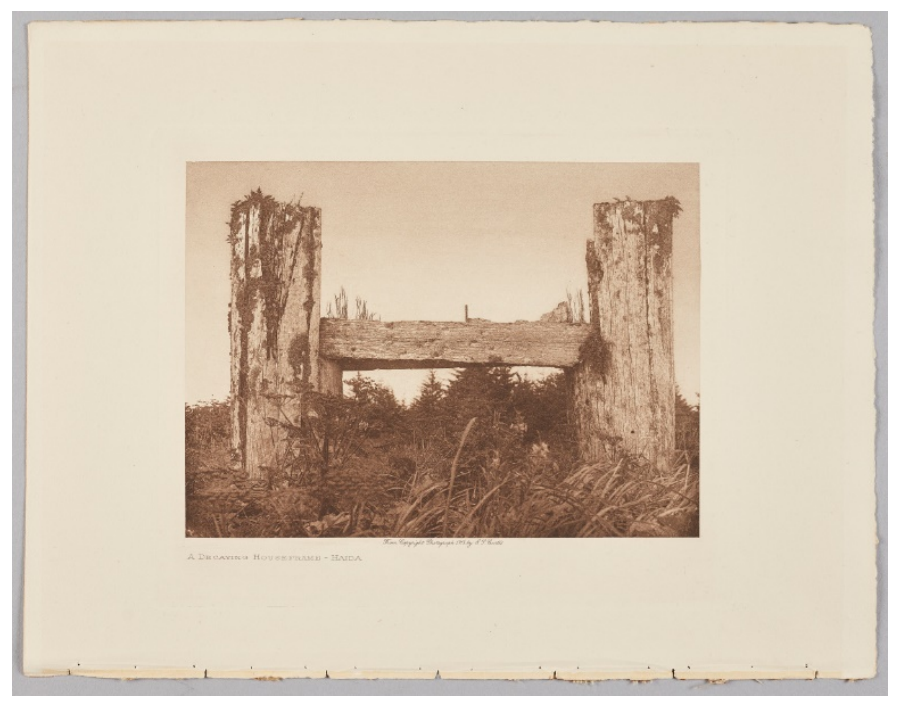

Title: A Decaying Houseframe - Haida

Date: 1915

Medium: Photogravure, Van Gelder paper

Dimensions: image: $13.8 \times 18.8 \mathrm{~cm} \mathrm{(5} \mathrm{1/2} \times 7$

$1 / 2$ in), plate: $17 \times 23 \mathrm{~cm}\left(63 / 4 \times 9 \frac{1}{16} \mathrm{in}\right)$,

sheet: $24.2 \times 31.3 \mathrm{~cm}\left(9 \frac{1}{2} \times 12 \mathrm{3} / 8\right.$ in)

Notes: Remnants of binding along bottom

edge

Provenance: Gift of Valerie Burton \& David

Milman, 1985

Facing Page: 130

Subject: Object

Constituent: John Andrew \& Son

"The roof of a primitive Haida house sloped from the middle to both sides, and the boards ran with the slope. Wall-boards were perpendicular. A tall, carved house-pole displaying various crests of the family generally stood in the middle of the front wall, the doorway sometimes being a mouth of one of the figures. The best houses were built over a fairly deep excavation lined with heavy timbers." (NAI volume 11: page 186)

By the time Curtis visited the Haida, they had almost completely modernized their way of life, including living in modern houses like those of white Americans. This decaying structure was most likely the only kind of "primitive" dwelling that Curtis could find to photograph. 


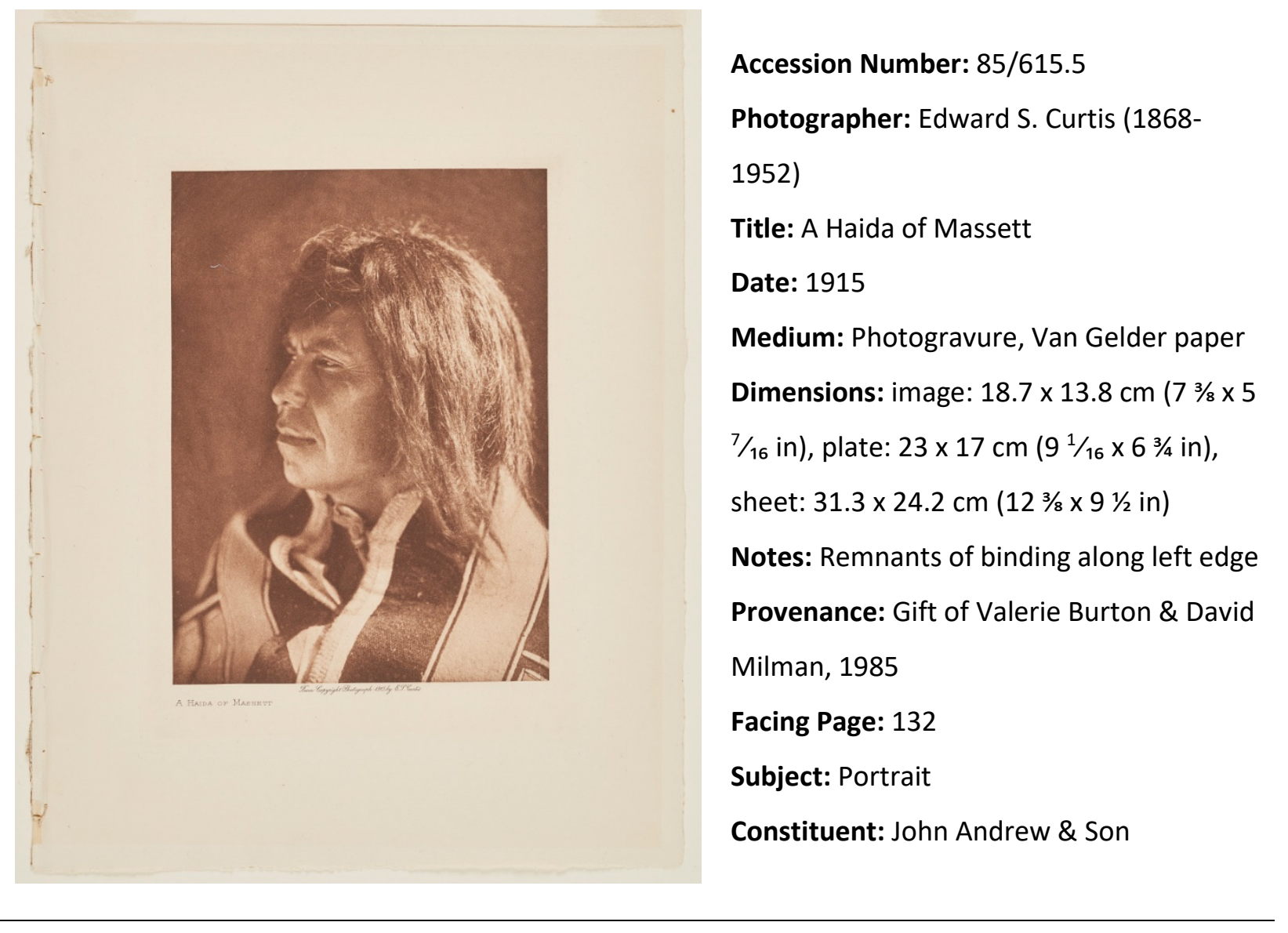




\section{Volume 11}

Accession Number: 85/615.44

Photographer: Edward S. Curtis (1868-

1952)

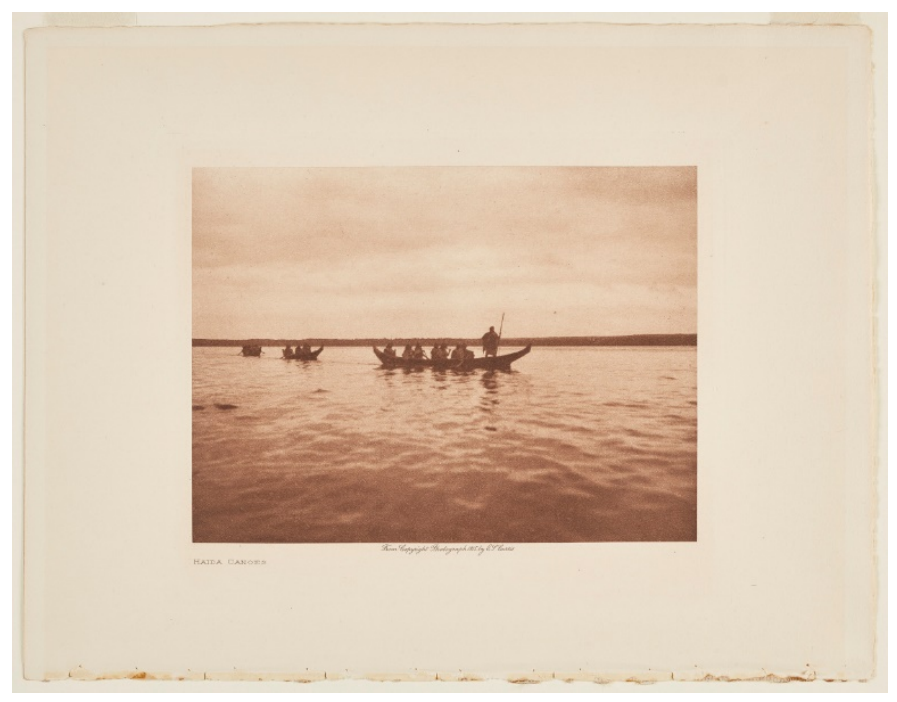

Title: Haida Canoes

Date: 1915

Medium: Photogravure, Van Gelder paper

Dimensions: image: $13.8 \times 18.5 \mathrm{~cm}(57 / 16 \mathrm{X}$

$\left.7 \frac{1 / 4}{\mathrm{in}}\right)$, plate: $18 \times 22 \mathrm{~cm}\left(7 \frac{1 / 16}{} \times 8^{11 / 16} \mathrm{in}\right)$,

sheet: $24.2 \times 31.3 \mathrm{~cm}\left(9 \frac{1}{2} \times 12 \frac{3}{8} \mathrm{in}\right)$

Notes: Remnants of binding along bottom

edge

Provenance: Gift of Valerie Burton \& David

Milman, 1985

Facing Page: 134

Subject: Genre Scene

Constituent: John Andrew \& Son

"Before the advent of steel tools, large canoes were commonly twenty-five to thirty feet long, and were made from logs seven spans (forty inches) thick. To fell such a tree with stone and bone implements was the work of four days. Afterward the length increased to seven or eight fathoms (thirty-five to forty feet). The largest one known to the Haida was the "Chief Canoe" at Massett. It is said to have been fifteen fathoms (seventy-five feet) long and about seven feet beam." (NAI volume 11: page 187) 


\section{Volume 11}

Accession Number: 85/615.49

Photographer: Edward S. Curtis (1868-

1952)

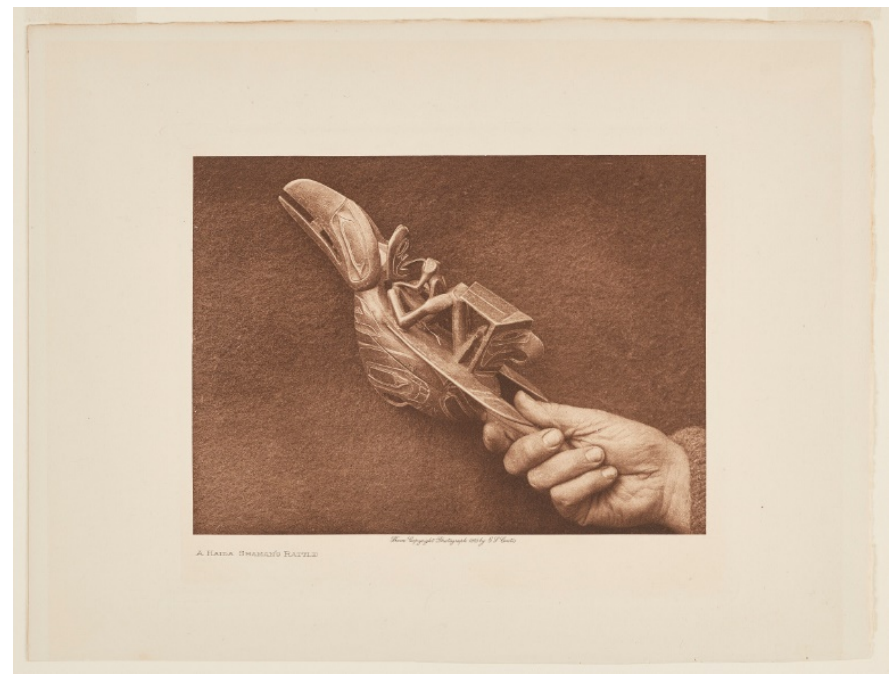

Title: A Haida Shaman's Rattle

Date: 1915

Medium: Photogravure, Van Gelder paper

Dimensions: image: $14.1 \times 19 \mathrm{~cm}\left(5 \frac{1}{2} \times 7\right.$ 1/2

in), plate: $19 \times 23 \mathrm{~cm}\left(7 \frac{1}{2} \times 9 \frac{1}{16}\right.$ in), sheet:

$24.2 \times 31.3 \mathrm{~cm}\left(9 \frac{1}{2} \times 12 \frac{3}{8} \mathrm{in}\right)$

Notes: None

Provenance: Gift of Valerie Burton \& David

Milman, 1985

Facing Page: 138

Subject: Object

Constituent: John Andrew \& Son

Curtis tried to capture all aspects of Native American tribal life. An object like this shows the artistry of the tribe and is also an important cultural object used by shamans and medicine-men. In Volume 11, Curtis references rattles as being used for healing rituals by shamans. This is also one of few images that displays the imagery of the tribes. In some volumes, Curtis included drawings that showed the symbolic imagery of the tribe. From the many pictures and thorough description of whaling rituals, the imagery of a whale on the rattle shows the importance of whales to the tribe. 


\section{Volume 11}

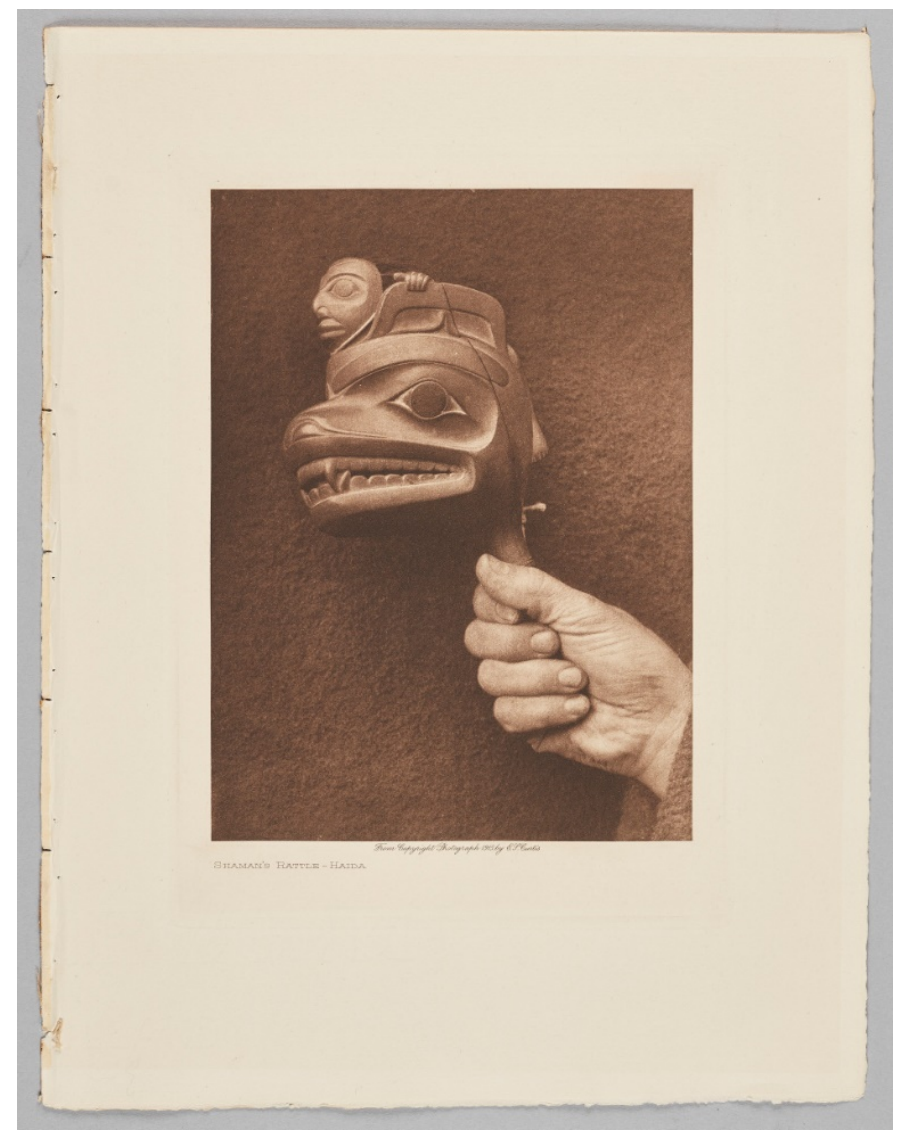

Accession Number: 85/615.50

Photographer: Edward S. Curtis (1868-

1952)

Title: Shaman's Rattle - Haida

Date: 1915

Medium: Photogravure, Van Gelder paper

Dimensions: image: $19 \times 14 \mathrm{~cm}\left(7 \frac{1}{2} \times 5\right.$ 1/2

in), plate: $23 \times 17 \mathrm{~cm}\left(9 \frac{1}{16} \times 6 \frac{3 / 4}{4}\right.$ ), sheet:

$31.3 \times 24.2 \mathrm{~cm}\left(12 \frac{3}{8} \times 9 \frac{1}{2} \mathrm{in}\right)$

Notes: Remnants of binding along left

edge, watermark across bottom

Provenance: Gift of Valerie Burton \& David

Milman, 1985

Facing Page: 142

Subject: Object

Constituent: John Andrew \& Son

This rattle is in the shape of a bear's head. See 85/615.49. 


\section{Volume 11}

Accession Number: 85/615.48

Photographer: Edward S. Curtis (1868-

1952)

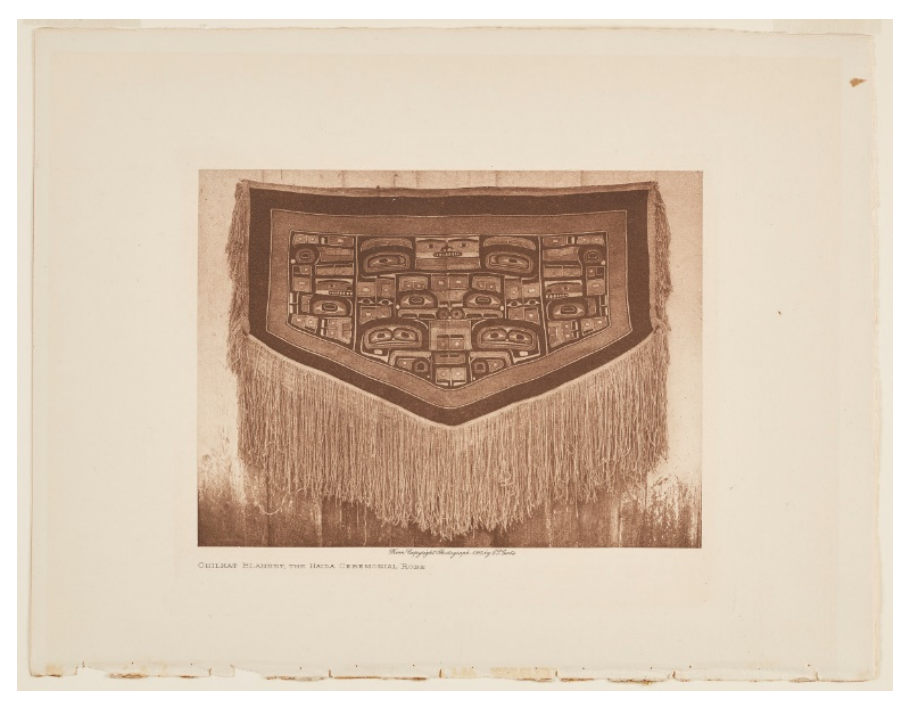

Title: Chilkat Blanket, The Haida

Ceremonial Robe

Date: 1915

Medium: Photogravure, Van Gelder paper

Dimensions: image: $14 \times 18.5 \mathrm{~cm} \mathrm{(5} \mathrm{1/2} \mathrm{x} 7$ 1/4

in), plate: $18 \times 22 \mathrm{~cm}$, sheet: $24.2 \times 31.3 \mathrm{~cm}$

$\left(9 \frac{1}{2} \times 12 \frac{3}{8}\right.$ in $)$

Notes: Remnants of binding along bottom

edge, watermark across right side

Provenance: Gift of Valerie Burton \& David

Milman, 1985

Facing Page: 144

Subject: Object

Constituent: John Andrew \& Son

"In the boyhood of an informant, that is, about 1855-1860, ten sacks of potatoes of about eighty pounds each were purchased for one blanket. These [potatoes] were raised by the Haida themselves in rather early times." (NAI volume 11 : page 123 , note 1 )

Curtis does not explain why blankets were considered so valuable. 


\section{Volume 11}



Accession Number: 85/615.6

Photographer: Edward S. Curtis (1868-

1952)

Title: Raven Chief of Skidegate - Haida

Date: 1915

Medium: Photogravure, Van Gelder paper

Dimensions: image: $18.8 \times 13.8 \mathrm{~cm}\left(7 \frac{1}{2} \times 5\right.$

$1 / 2$ in), plate: $23 \times 17 \mathrm{~cm}\left(9 \frac{1}{16} \times 6 \frac{3}{4} \mathrm{in}\right)$,

sheet: $31.3 \times 24.2 \mathrm{~cm}\left(12 \frac{3}{8} \times 9 \frac{1}{2} \mathrm{in}\right)$

Notes: Remnants of binding along left edge

Provenance: Gift of Valerie Burton \& David

Milman, 1985

Facing Page: 146

Subject: Portrait

Constituent: John Andrew \& Son

Similar outfit to $85 / 615.9$ and plate 398 . See $85 / 615.9$ for more information. 


\section{Volume 11}

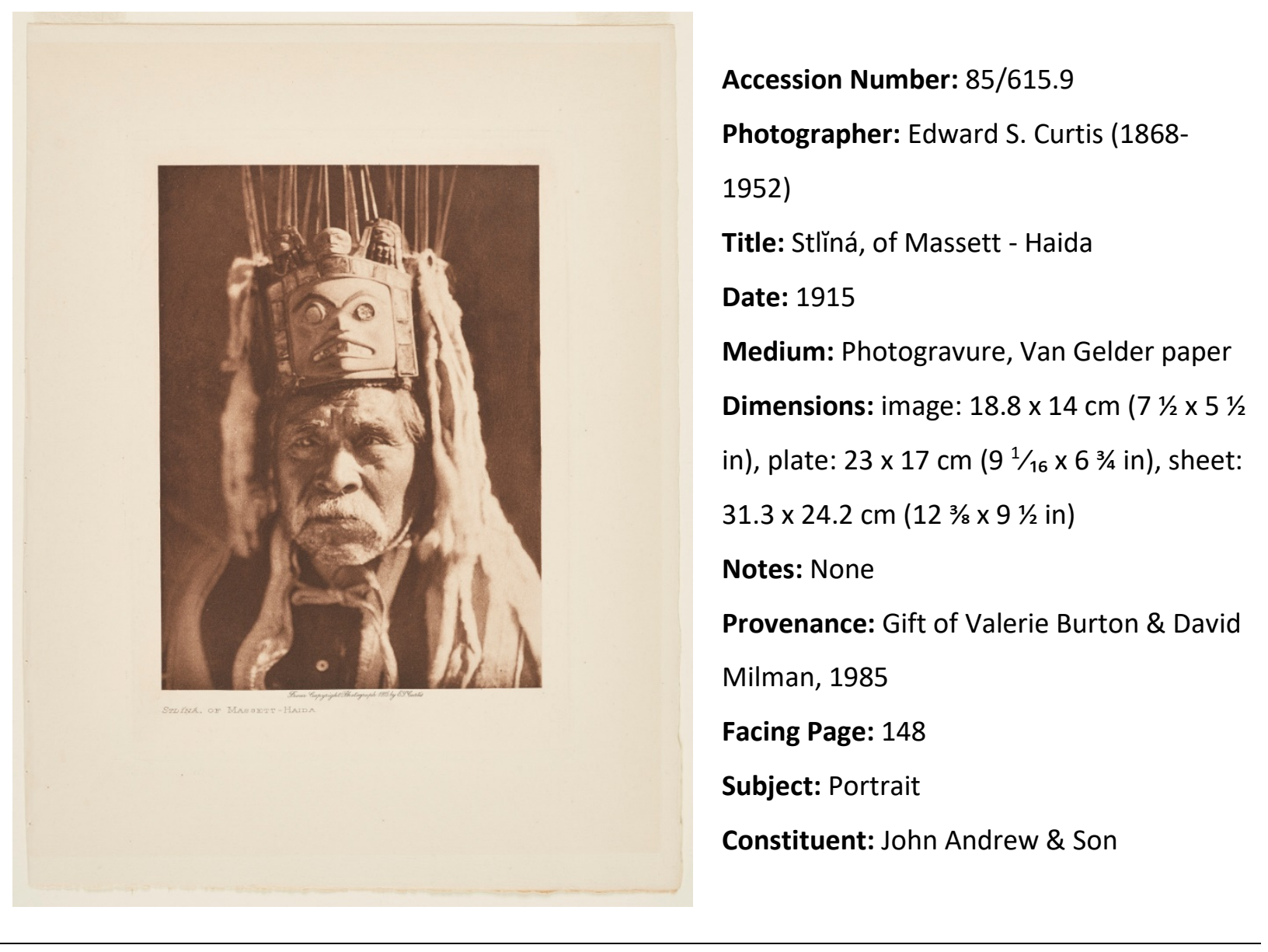

"The head-dress is a 'dancing hat,' and consists of a carved wooden mask surmounted by numerous sealion bristles and with many pendent strips of ermine-skin." (NAI portfolio 11: caption for 398)

Same subject as plate 398 and similar outfit to 85/615.6. 


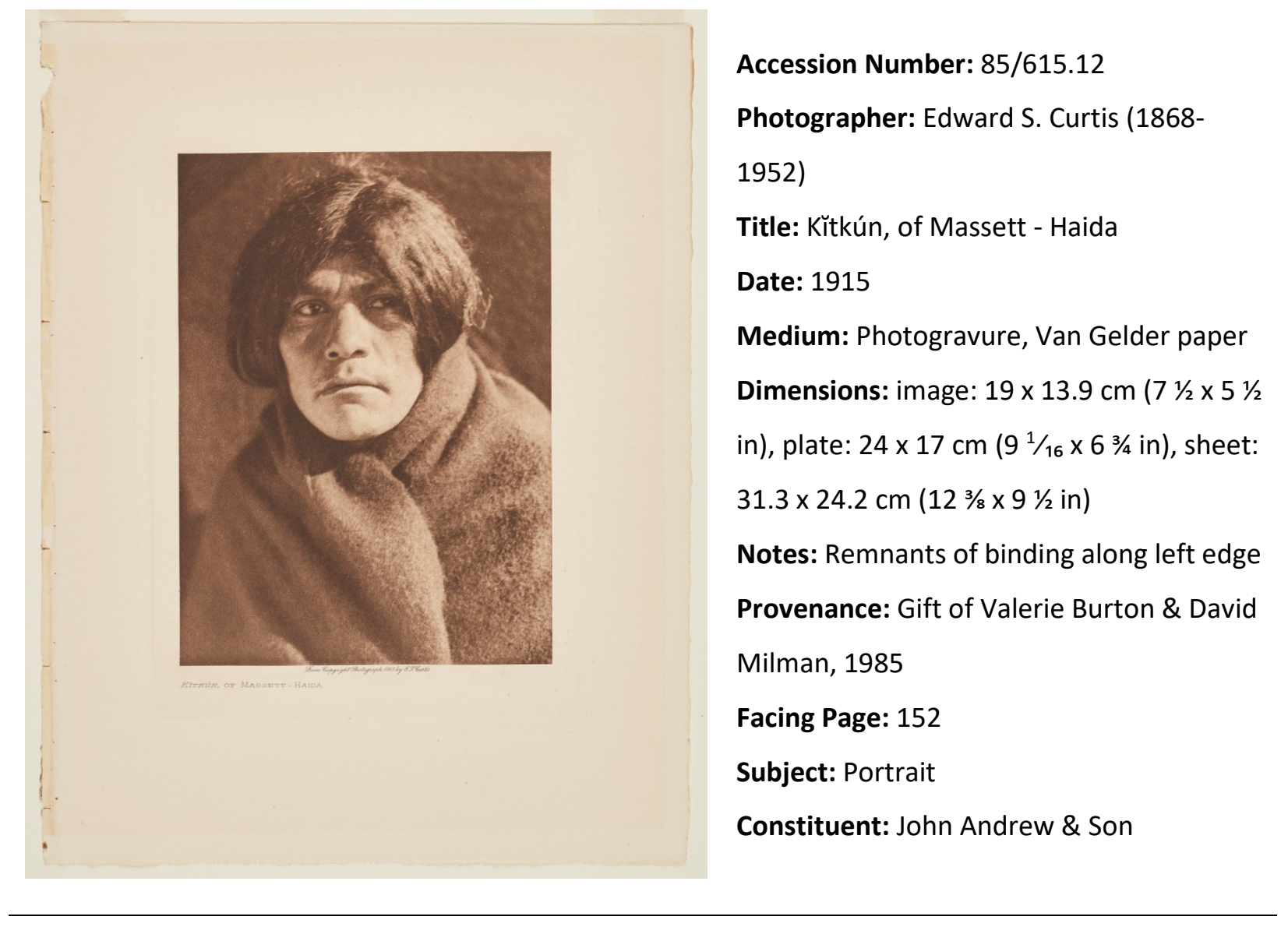

See 85/615.10 and 85/615.7. 


\section{Volume 11}

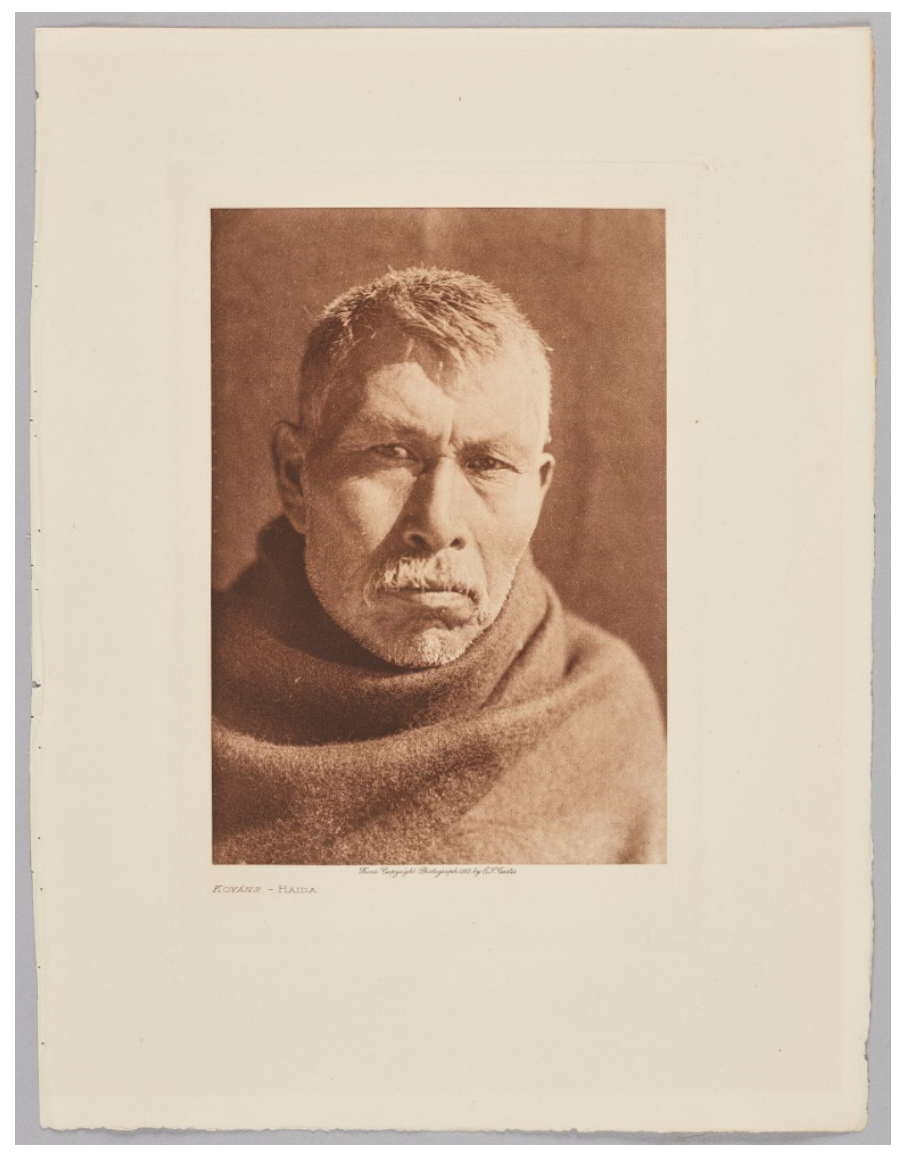

Accession Number: 85/615.7

Photographer: Edward S. Curtis (1868-

1952)

Title: Koyáns - Haida

Date: 1915

Medium: Photogravure, Van Gelder paper

Dimensions: image: $18.5 \times 13 \mathrm{~cm}\left(7 \frac{1}{4} \times 5\right.$ 1/8

in), plate: $23 \times 17 \mathrm{~cm}\left(9 \frac{1}{16} \times 6 \frac{3 / 4}{\mathrm{in}}\right)$, sheet:

$31.3 \times 24.2 \mathrm{~cm}\left(12 \frac{3}{8} \times 9 \frac{1}{2}\right.$ in $)$

Notes: Remnants of binding along left edge

Provenance: Gift of Valerie Burton \& David

Milman, 1985

Facing Page: 156

Subject: Portrait

Constituent: John Andrew \& Son

Curtis often used blankets to cover modern clothing. One of the goals of Curtis's project was to photograph Native Americans as they were before contact with settlers. This meant excluding modern objects and clothing. By the early twentieth century, most Native Americans wore clothing of the same style as settlers preventing Curtis from photographing "primitive" clothing. The blanket in this image appears to be made from felt and appears in $85 / 615.12,85 / 615.14$, covering clothing and possibly serves as the background for the pictures of rattles. 


\section{Volume 11}

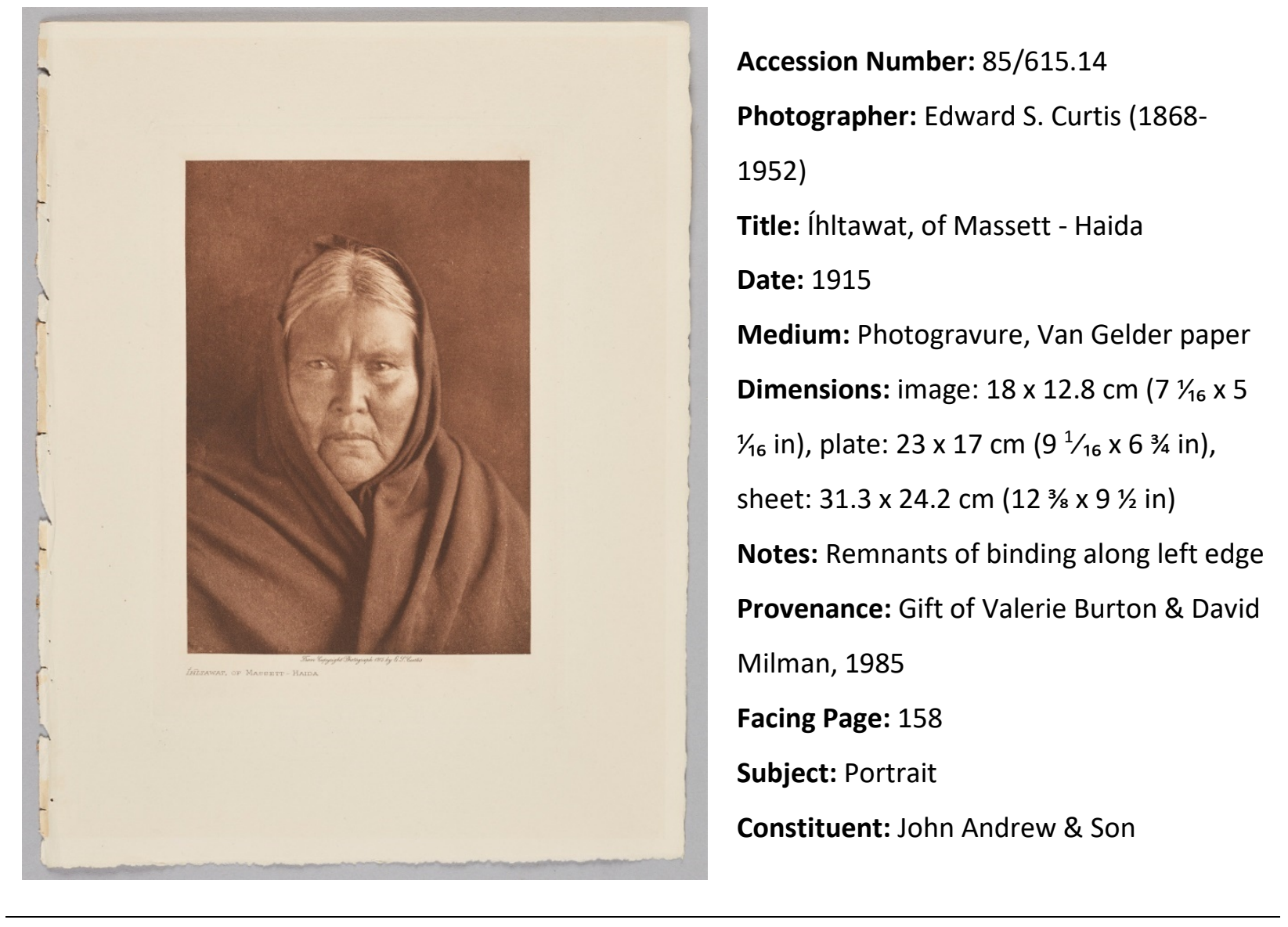

Both this image and 85/615.15 depict women similarly draped with blankets. The two Massett women may have been photographed within moments of each other. 


\section{Volume 11}

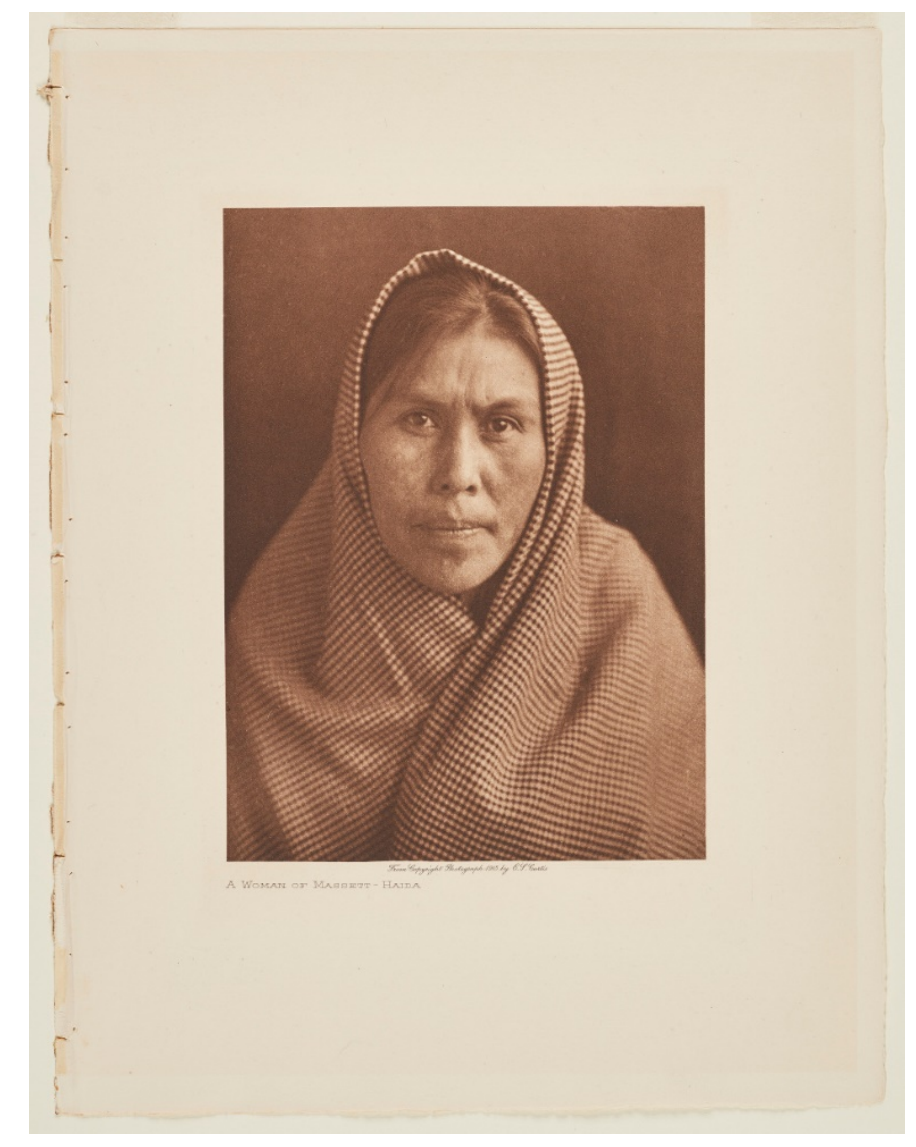

Accession Number: 85/615.15

Photographer: Edward S. Curtis (1868-

1952)

Title: A Woman of Massett - Haida

Date: 1915

Medium: Photogravure, Van Gelder paper

Dimensions: image: $18.8 \times 13.8 \mathrm{~cm}\left(7 \frac{1}{2} \times 5\right.$

$1 / 2$ in), plate: $23 \times 17 \mathrm{~cm}\left(9 \frac{1}{16} \times 6 \frac{3}{4} \mathrm{in}\right)$,

sheet: $31.3 \times 24.2 \mathrm{~cm}\left(12 \frac{3}{8} \times 9 \frac{1}{2} \mathrm{in}\right)$

Notes: Remnants of binding along left edge

Provenance: Gift of Valerie Burton \& David

Milman, 1985

Facing Page: 162

Subject: Portrait

Constituent: John Andrew \& Son

See 85/615.14. 


\section{Volume 11}

Accession Number: 85/615.51

Photographer: Edward S. Curtis (1868-

1952)

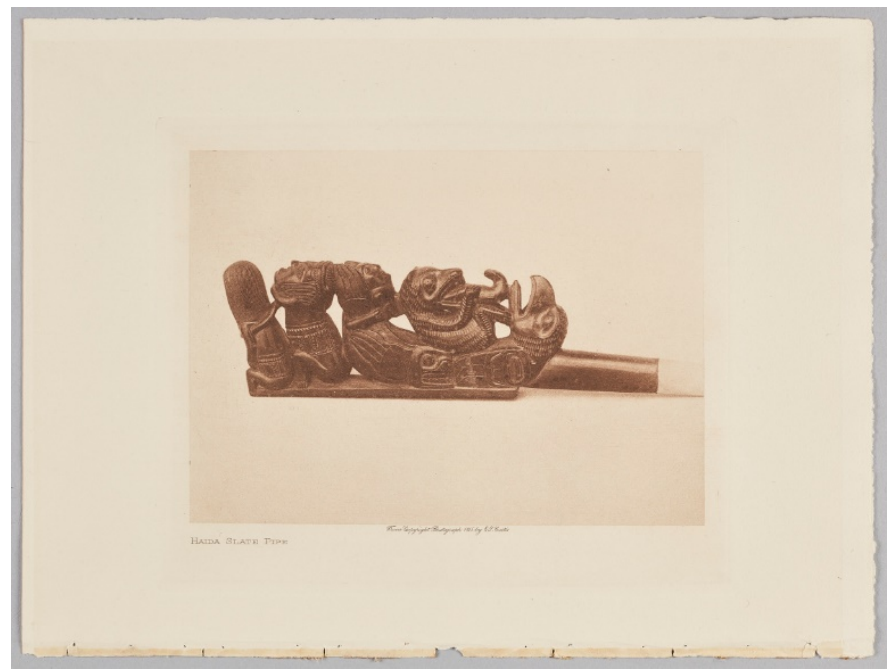

Title: Haida Slate Pipe

Date: 1915

Medium: Photogravure, Van Gelder paper

Dimensions: image: $13.7 \times 18.6 \mathrm{~cm} \mathrm{(5} \mathrm{3/8} \times 7$

$5 / 16$ in), plate: $18 \times 22 \mathrm{~cm}(71 / 16 \times 811 / 16$ in),

sheet: $24.2 \times 31.3 \mathrm{~cm}\left(9 \frac{1}{2} \times 12 \frac{3}{8} \mathrm{in}\right)$

Notes: Remnants of binding along bottom

edge

Provenance: Gift of Valerie Burton \& David

Milman, 1985

Facing Page: 166

Subject: Object

Constituent: John Andrew \& Son

"In carving wood and bone the Haida were not surpassed south of Alaska. They still make quantities of small figures in black slate." (NAl volume 11: page 186) 
Volume 17: Tewa and Zuñi, 1926

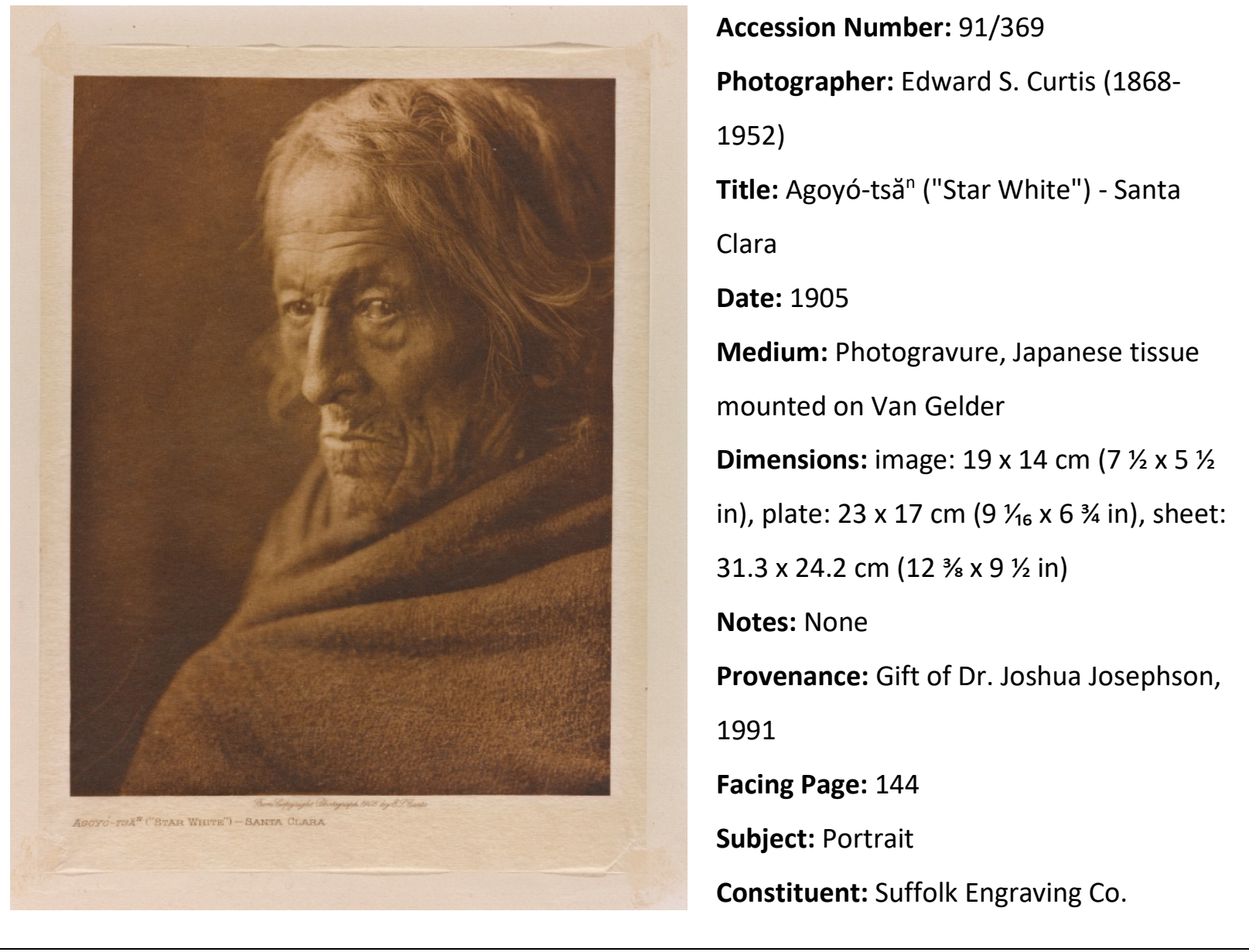

This image was taken at the pueblo of Santa Clara, a part of the Tewa tribe. Curtis noted, "The Tewa pueblos in New Mexico, from north to south, are: San Juan, Santa Clara and San Ildefonso on or near the banks of the river, and Nambé and Tesuque in the broken country where the valley floor gives way to the foothills of the Sangre de Cristo range." (NAI volume 17: page 3) 


\section{Portfolio Prints}

Portfolio 8: Nez Perces, Wallawalla, Umatilla, Cayuse, and Chinookan Tribes, 1911

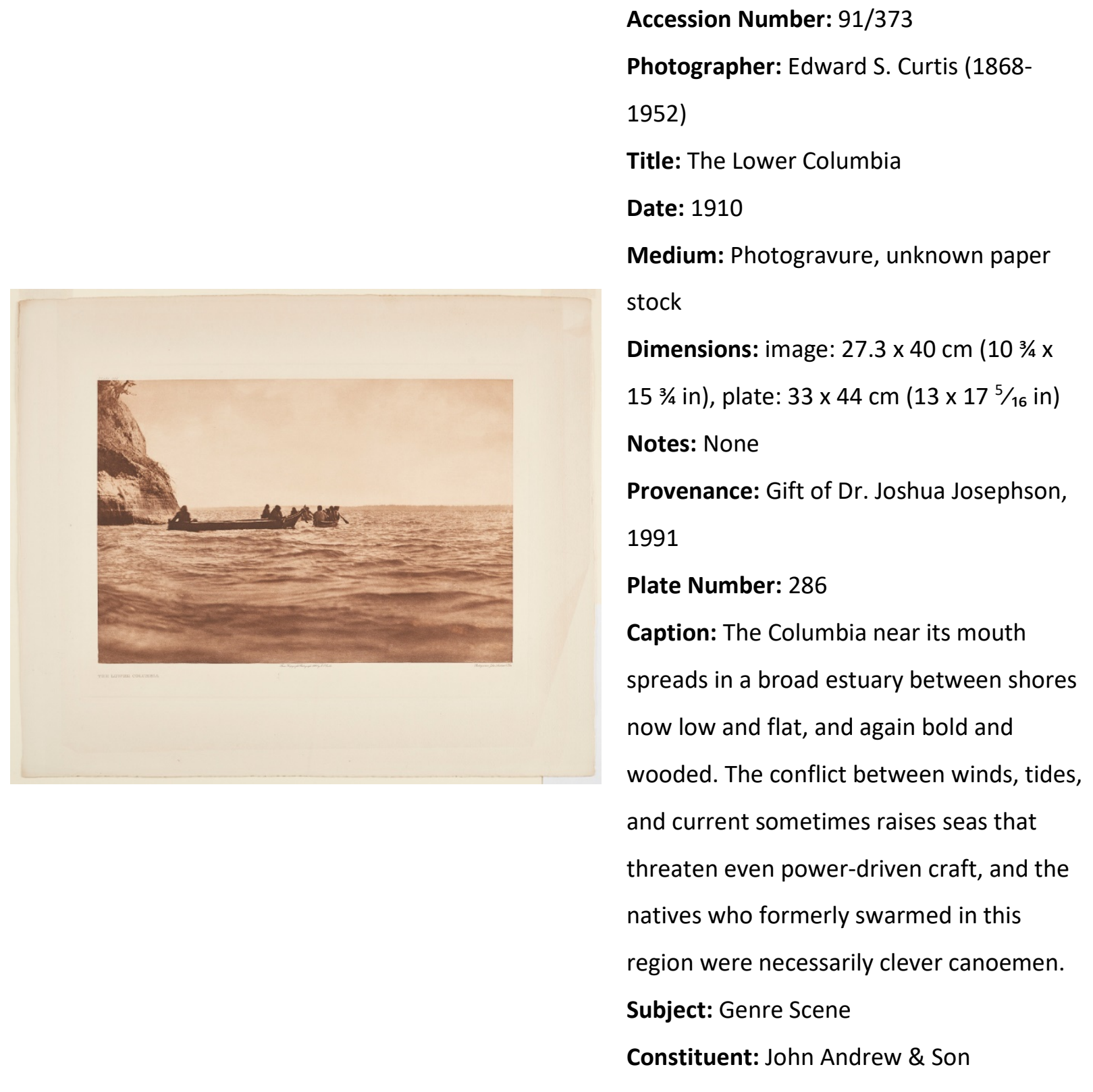

The caption of this print speaks to the characteristics of the water near the mouth of the Colombia River; however, the image shows nothing of the dangers of the tides, winds, and currents. Curtis remarks that the inhabitants of the river had to be clever canoemen to navigate the water but the image does not show the ingenuity of the canoemen. Without the caption, one might think the water was peaceful. 
Accession Number: 91/370

Photographer: Edward S. Curtis (1868-

1952)

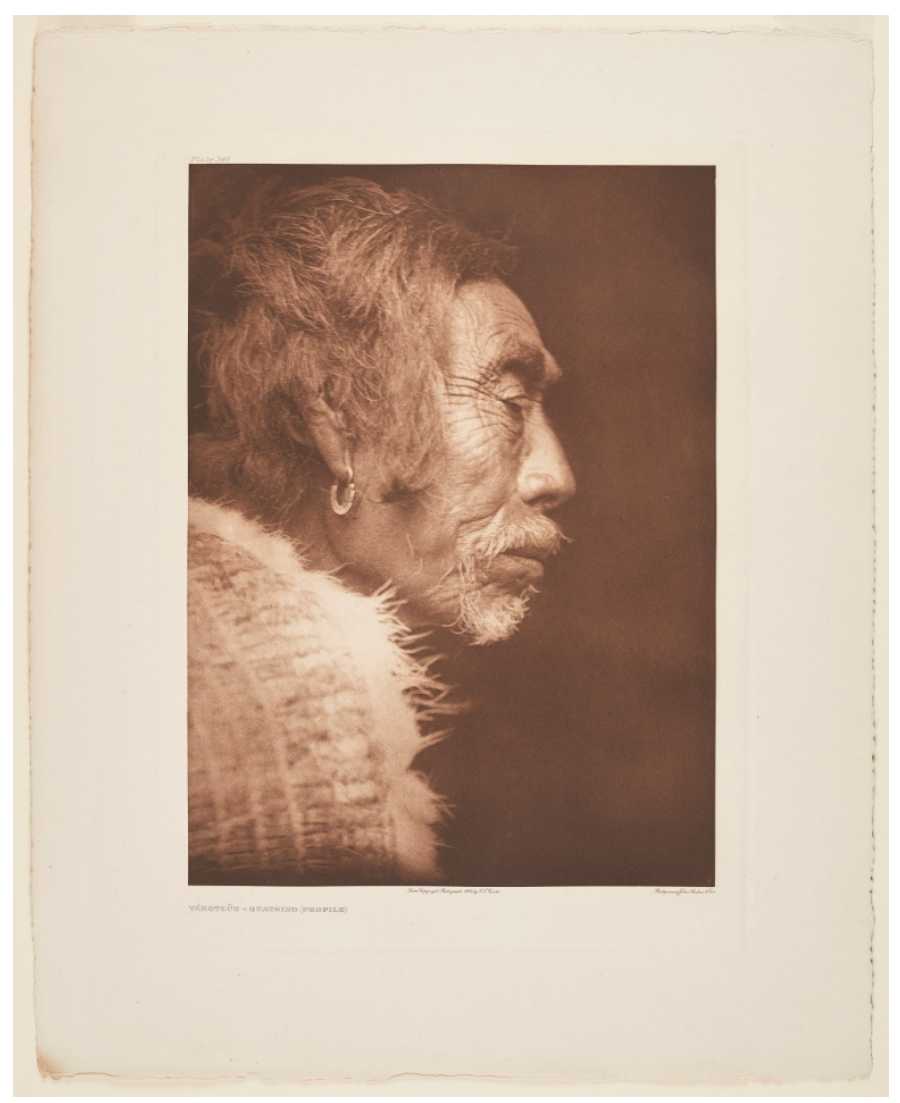

Title: Yákotlŭs - Quatsino (Profile)

Date: 1914

Medium: Photogravure, unknown paper stock

Dimensions: image: $38.8 \times 28.1 \mathrm{~cm} \mathrm{(15} \mathrm{1/4} \mathrm{X}$

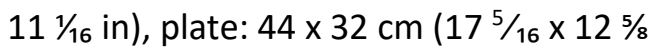

in)

Notes: None

Provenance: Gift of Dr. Joshua Josephson, 1991

Plate Number: 346

Caption: In physique and intelligence the Quatsino seem inferior to the other Kwakiutl tribes. This plate illustrates the artificial deformation of the head, which formerly was quite general on the North Pacific coast. The process is described in Volume X, page 52 .

Subject: Portrait

Constituent: John Andrew \& Son

"Until about the middle of the nineteenth century artificial deforming of the head was general among the Kwakiutl, while the tribes of Quatsino sound carried the practice to the greatest extremes. On the fourth day after a child's birth came a woman whose profession was that of head-binder. After anointing the infant's head with silver-perch oil, she wrapped tightly about it a two-inch strip of deerskin or of thin, dry kelp. The baby was then laid in the cedar-bark floss. A pad of floss was bound tightly over the forehead, and other pads were stuffed into the space between the temples and the sides of the cradle, the purpose being to produce a straight line from the tip of the nose to the crown of the head....After about two weeks the head-binder removed the bandage, oiled the skin, ... and adjusted a wider binding. Thus the process continued for about four months, the width of the bandage being gradually increased as the head grew longer. ...At the end of four months... the skull assumed a rounded, elongate shape...." (NAl volume 10: page 52-53) 
Portfolio 13: Hupa, Yurok, Karok, Wiyot, Tolowa, Tututni, Shasta, Achomawi, Klamath, 1924

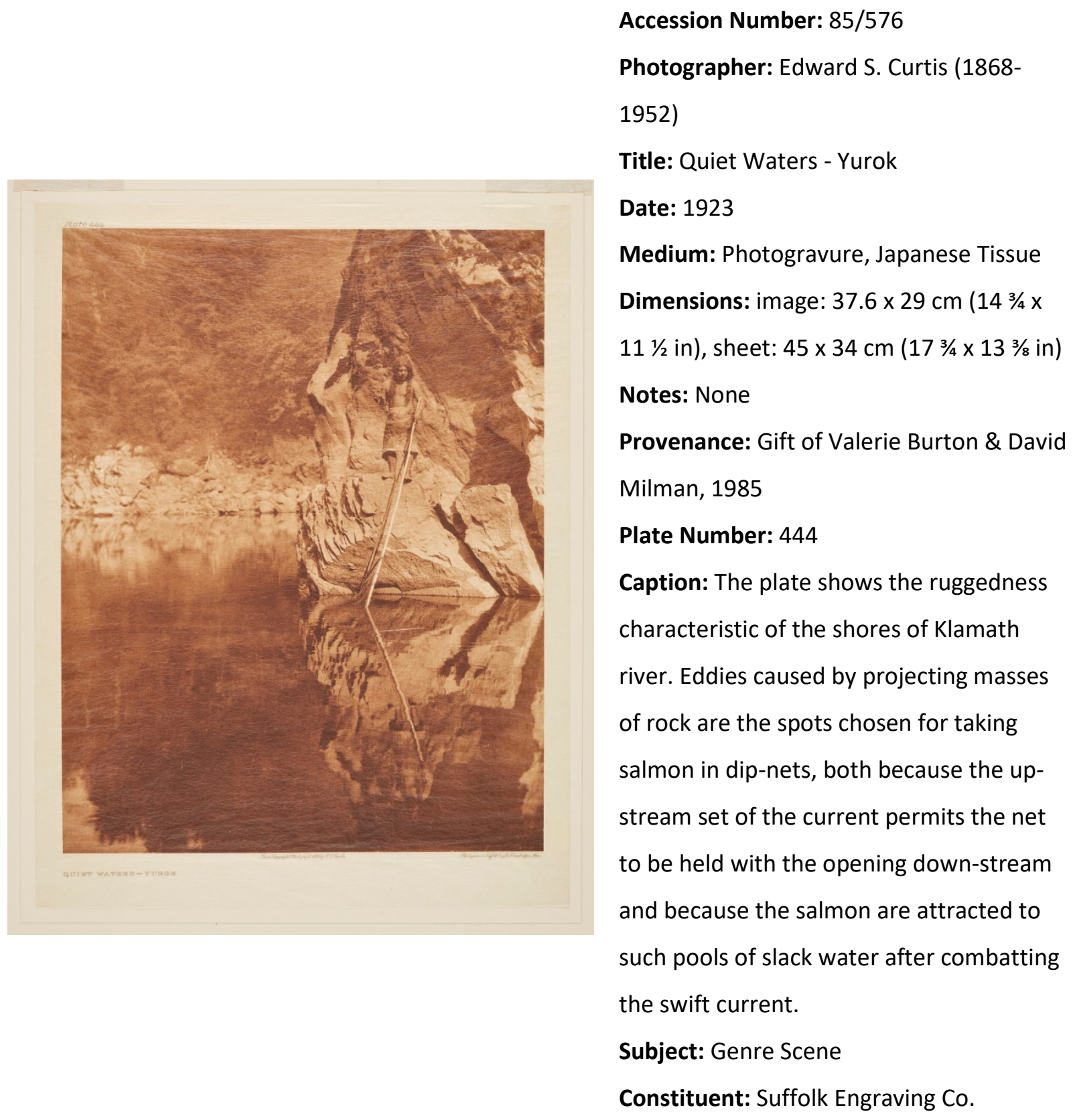

The caption of this photograph in comparison with the composition and title speak to different approaches. The text is ethnographic and descriptive of the landscape and fishing, but the image shows only a solitary figure amongst the rocks and water. The figure blends into the landscape and is hard to distinguish from the surrounding rock, creating a visual metaphor for the interdependence between the individuals of the tribe and the land. While one can see the rugged landscape that Curtis speaks of, the viewer would not recognize from the title or the image that this was a good spot for fishing. The Klamath River flows through Oregon and California and empties into the Pacific Ocean. 
Portfolio 15: Shoshoneans, Digueños, and Washo, 1926

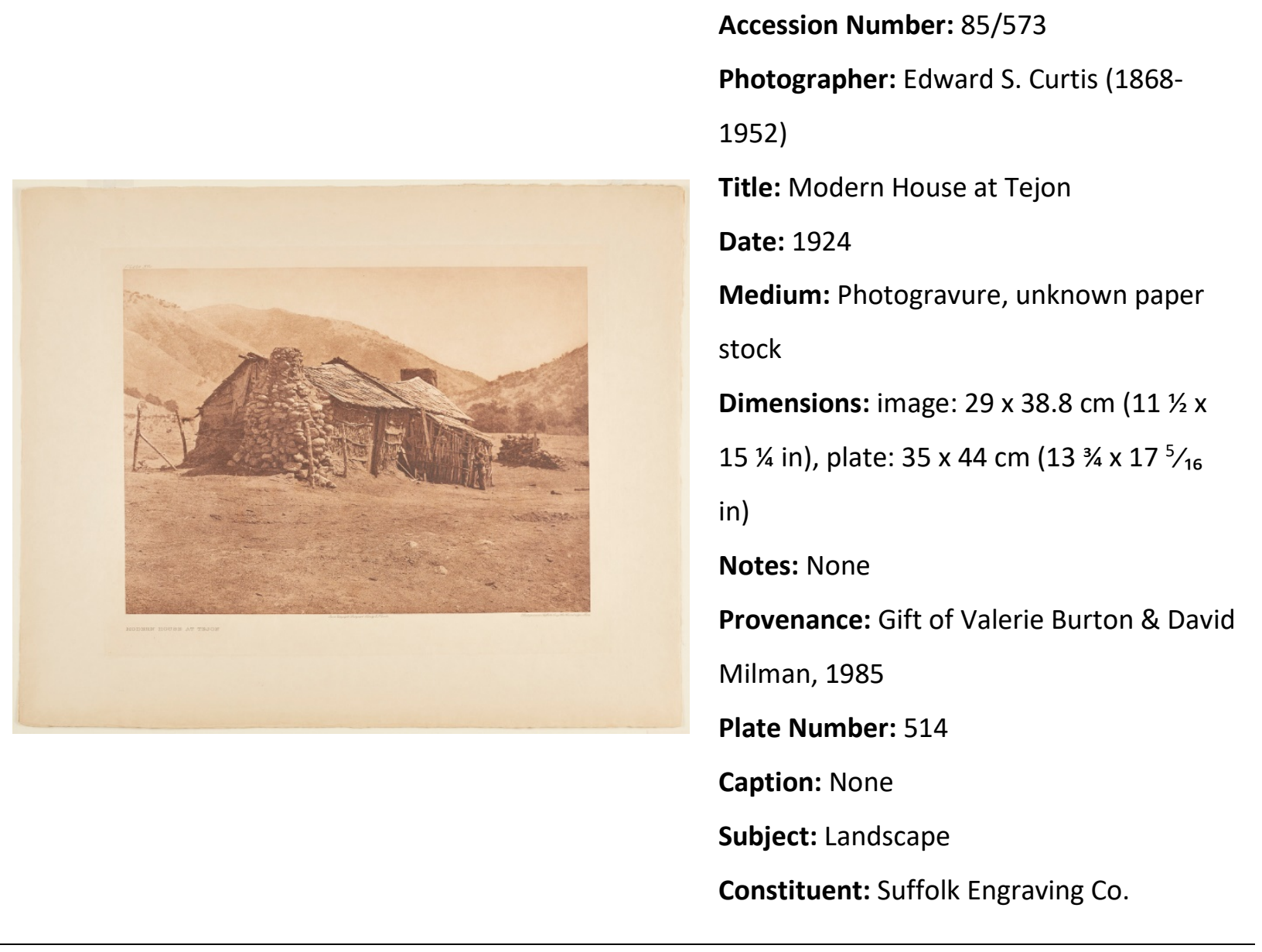

The index of Volume 15 refers to this plate as a Serrano house, which refers to the tribe affiliation of the owners, found under the word "houses." The Serrano people are affiliated with the Cahuilla people. The dwelling pictured here is considered modern because it is not the "primitive" flat-roofed, mesquite house. 


\section{Portfolio 15}

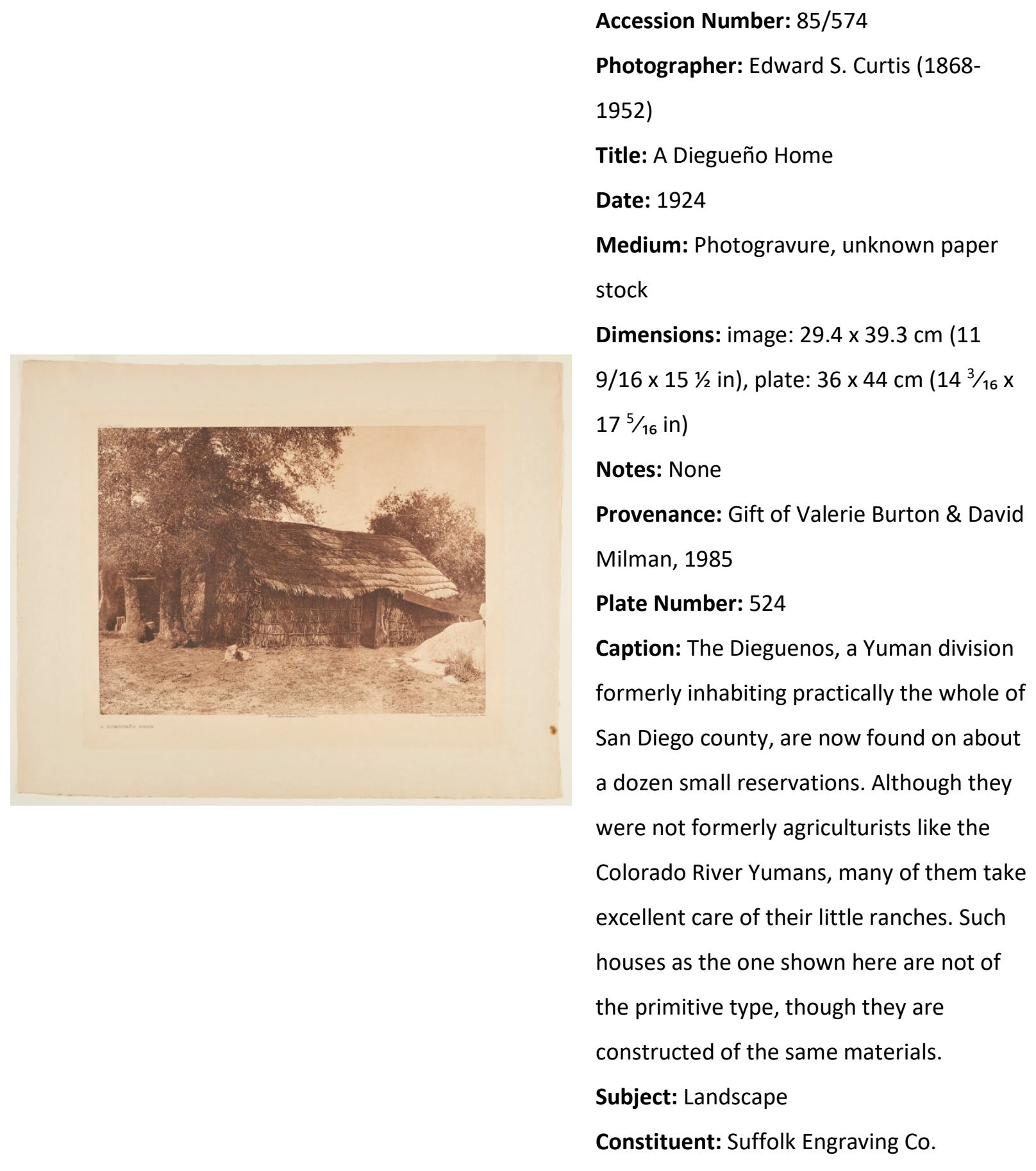

This image shows the blending of the past with the modern, traditional materials with a new design.

Though Curtis often reiterates that he wished to show Native Americans as they were before contact with white Europeans, many of his images, like this one, show the influence of settlers. 


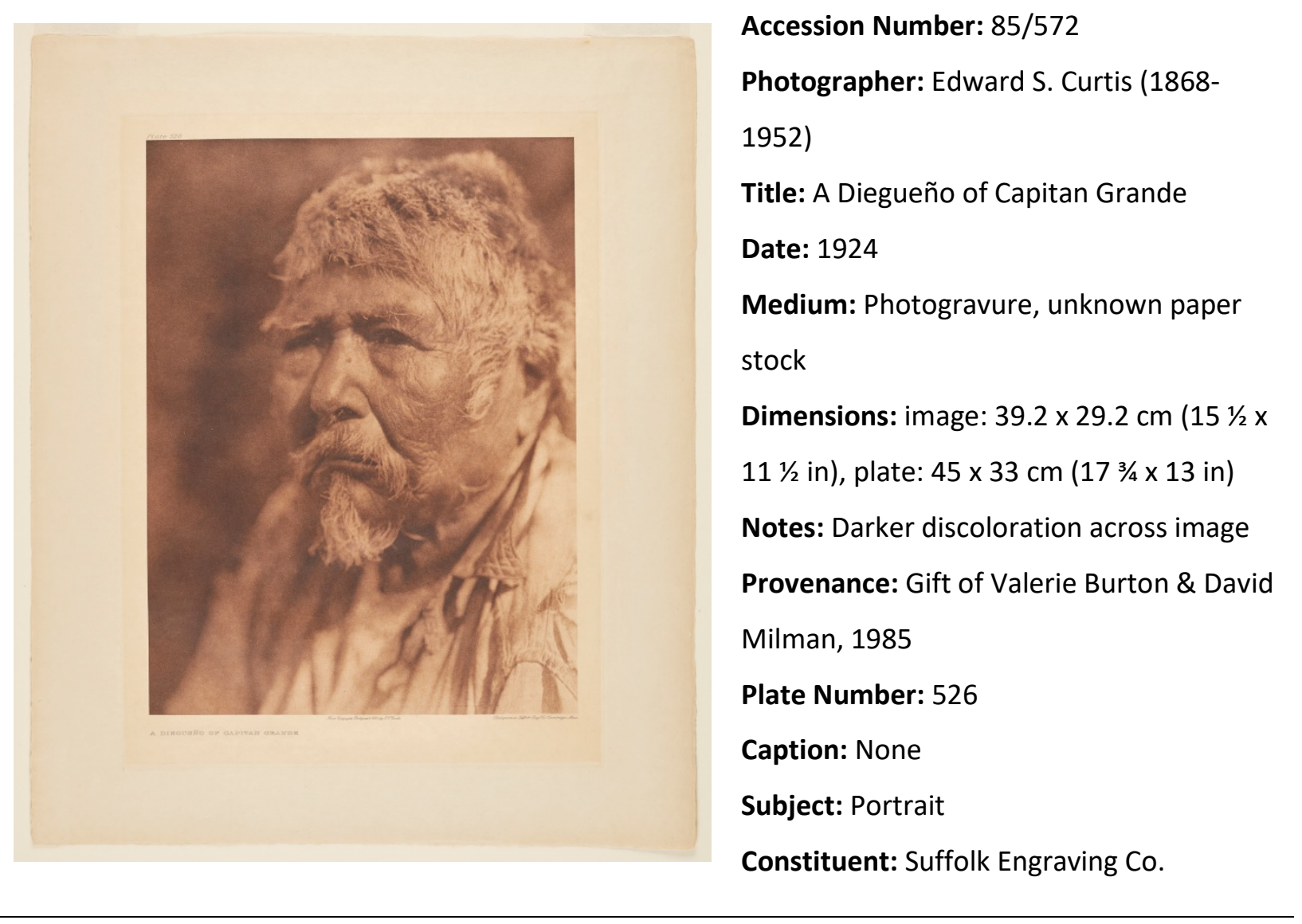

Capitan Grande is a reservation in San Diego County, California. 


\section{Portfolio 16: Tiwa and Keres, 1926}

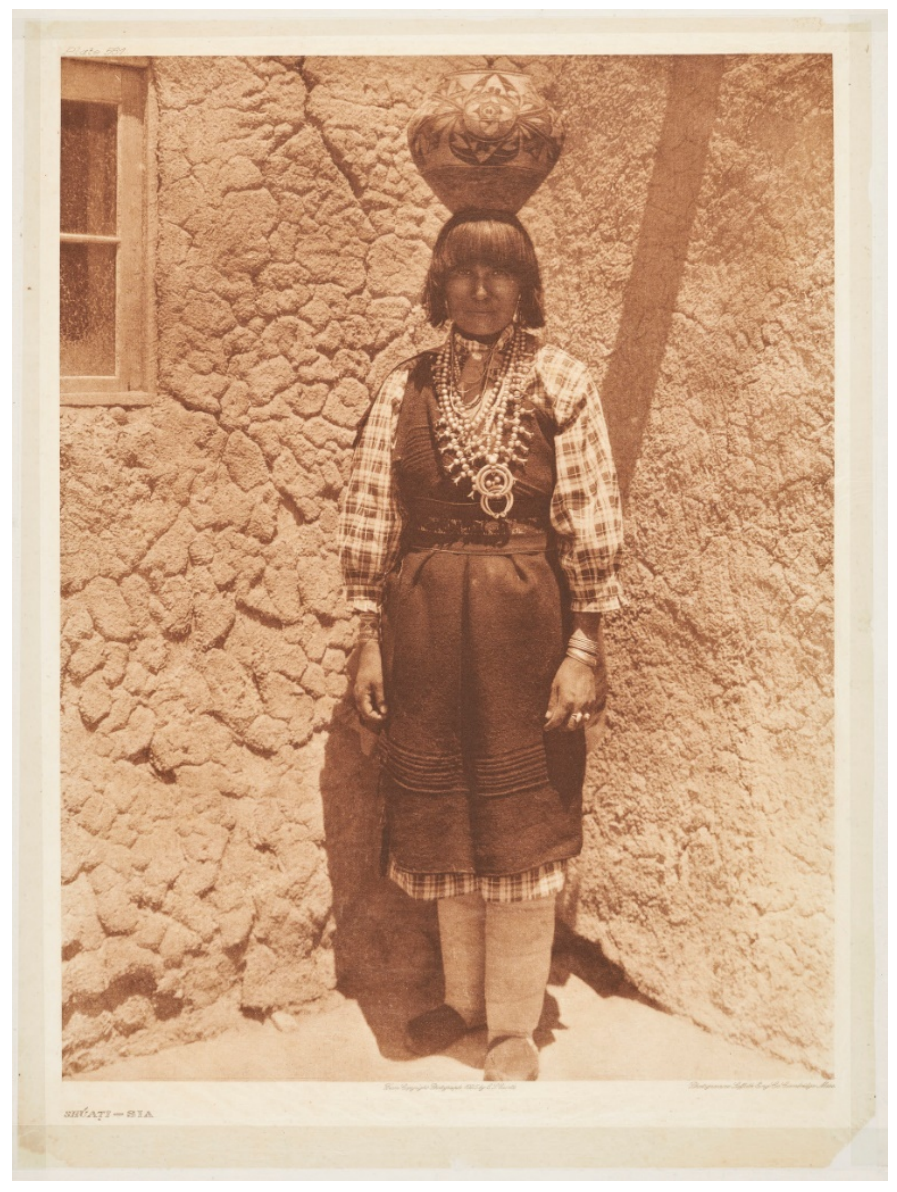

Accession Number: 2006/343

Photographer: Edward S. Curtis (1868-

1952)

Title: Shúati - Sia

Date: 1925

Medium: Photogravure, Japanese tissue

Dimensions: image: 39 × 29 cm (153/8 x 11

$1 / 2$ in), sheet: $45 \times 34 \mathrm{~cm}\left(173 / 4 \times 13 \frac{3}{8}\right.$ in)

Notes: Torn corners

Provenance: Gift of John Richmond Harris, 2006

Plate Number: 561

Caption: None

Subject: Portrait

Constituent: Suffolk Engraving Co.

The pueblo of Sia was known for the excellence of its earthenware. (NAl volume 16: page 80)

"The Keres Indians, a distinct linguistic stock, are found in seven pueblos, five of which are on the Rio Grande and it affluent Rio Jemez, and two nearly a hundred miles southwestward. The eastern group are Cochiti, Santo Domingo, and San Felip on the Rio Grande, and Santa Ana and Sia on Rio Jemez." (NAI volume 16: page 65) 


\section{Portfolio 16}

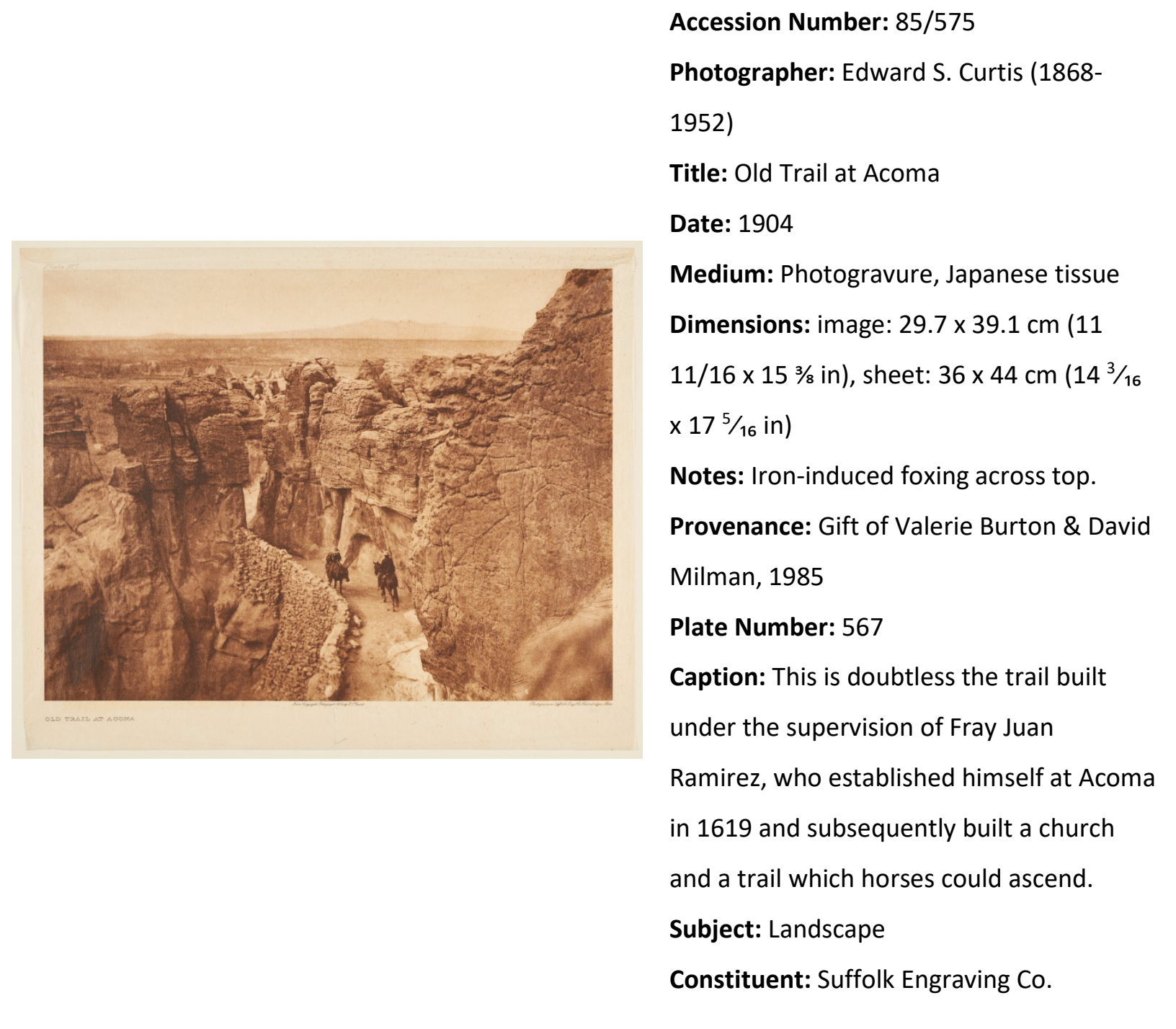

Photogravures on Japanese tissue are impressive to look at. The material itself is translucent and this translucency creates an incredible depth in the image. The curving trail and rocks draw the eye through the image, from the horsemen meeting on the trail to the faraway butte along the horizon. The composition of the image stands for itself in any material but on Japanese tissue, the shadows and highlights have more depth and nuance. 


\section{Portfolio 16}

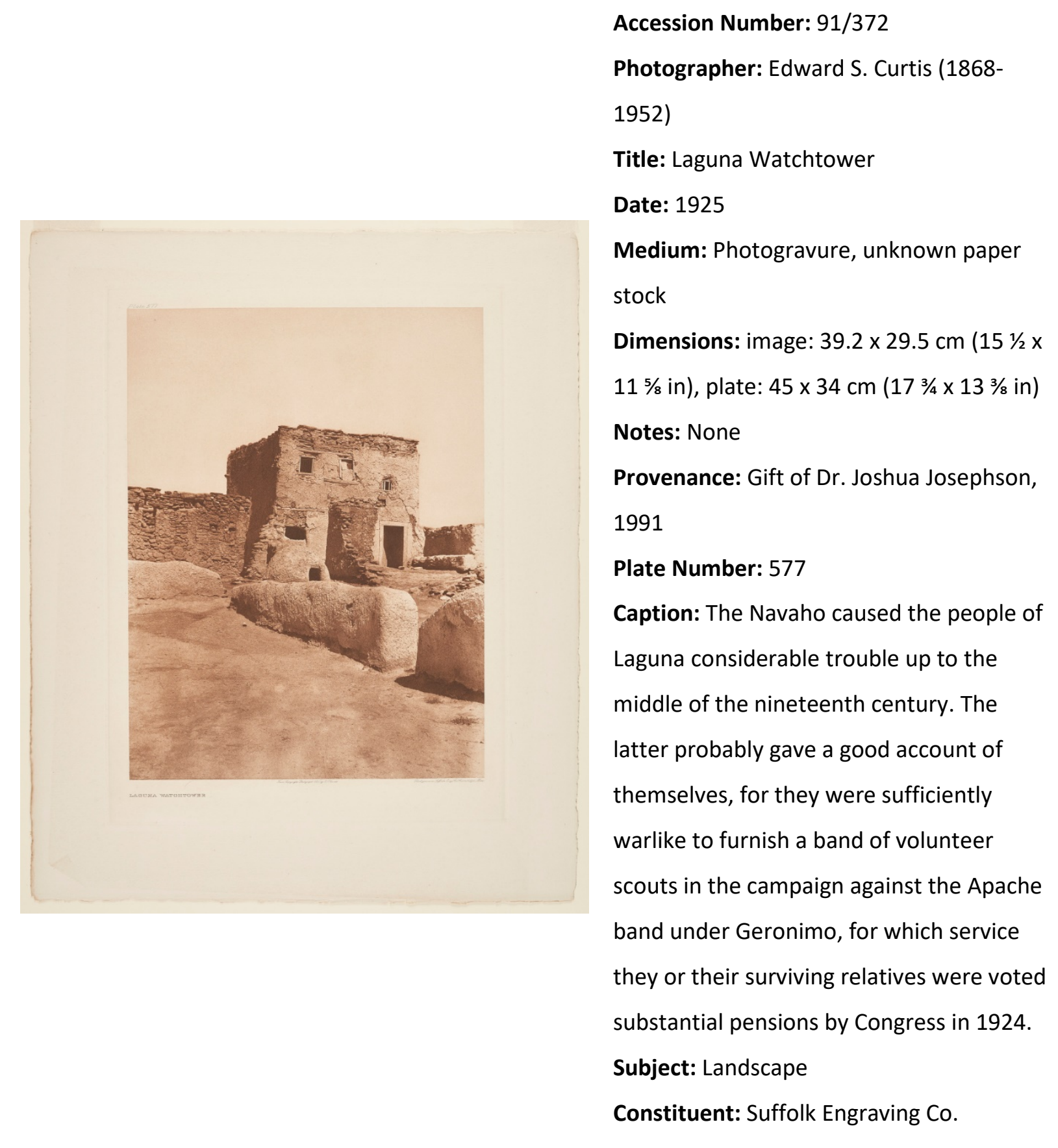

In addition to his portraits, Curtis took many photographs such as this one of architectural structures. Curtis's caption gives a short historical note about the watchtower that goes with the generality of the picture. In both the volumes and the portfolios, Curtis included a variety of images covering all facets of life, which includes structures and dwellings. To include this image in a portfolio, Curtis must have felt that this image was more successful in capturing the feeling of the place. Now that the Indian wars were over the watchtower no longer had a purpose and was a relic of the past. 
Portfolio 19: Oklahoma, Wichita, Cheyenne, Oto, Comanche, and Peyote Cult, 1930

Accession Number: 91/371

Photographer: Edward S. Curtis (1868-

1952)

Title: Woísta -Cheyenne Woman

Date: 1927

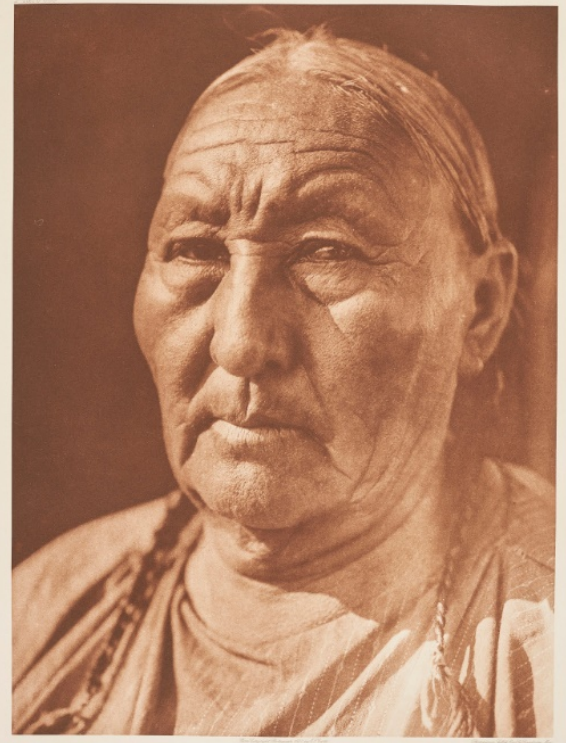

Medium: Photogravure, unknown paper stock

Dimensions: image: 38.7 x $29 \mathrm{~cm} \mathrm{(15} \mathrm{1/4} \mathrm{X}$ $11 \frac{1}{2}$ in), plate: $45 \times 34 \mathrm{~cm}\left(17 \frac{3}{4} \times 13 \frac{3}{8} \mathrm{in}\right)$ Notes: Recto: Stamped on bottom center: 10701

Provenance: Gift of Dr. Joshua Josephson, 1991

Plate Number: 669

Caption: Remarkable strength of character is depicted in the features of this woman, and indeed in those of all the Cheyenne. Their former life was such that only the fittest could survive.

Subject: Portrait

Constituent: Suffolk Engraving Co. 


\section{Other Works}

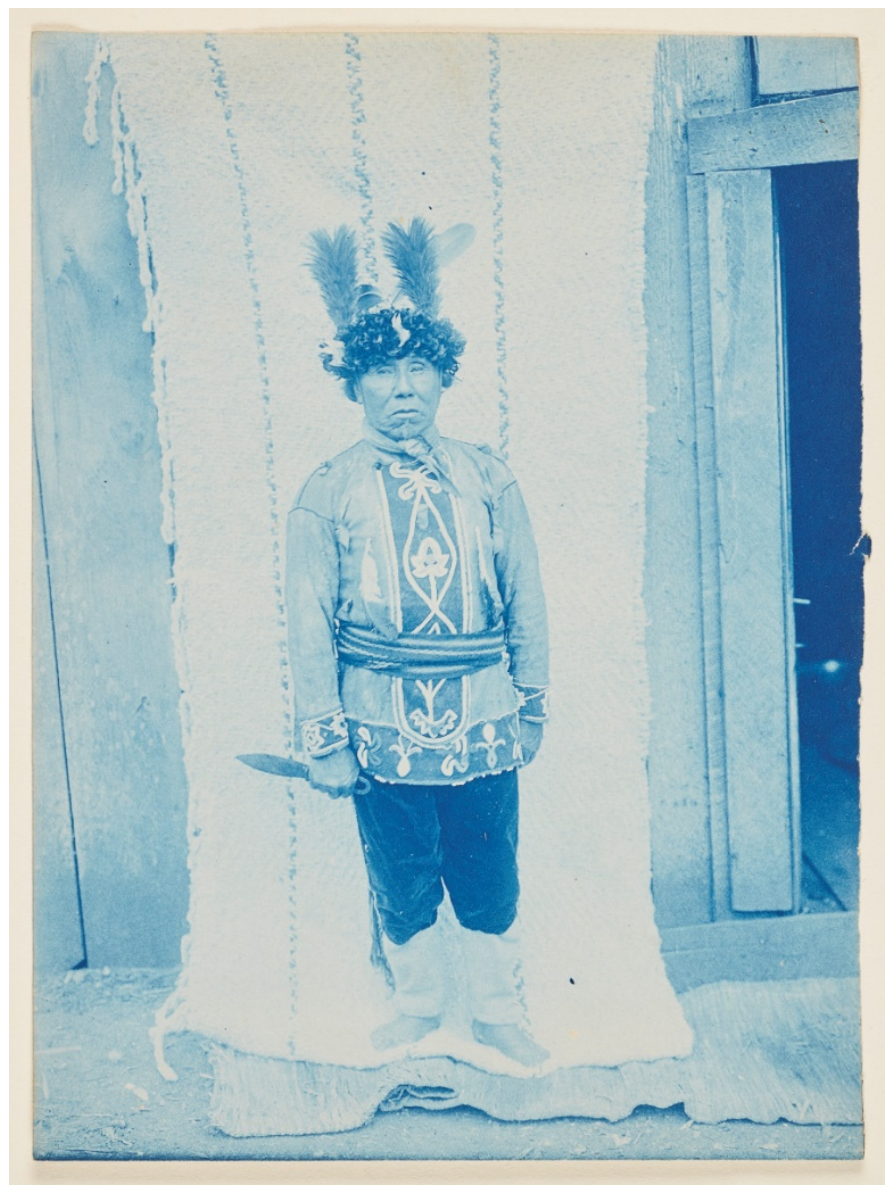

Accession Number: 85/571

Photographer: Edward S. Curtis (1868-

1952)

Title: Cowichan Warrior

Date: 1912

Medium: cyanotype

Dimensions: sheet: $20.5 \times 15.1 \mathrm{~cm}(81 / 16 \times 5$

$15 / 16$ in)

Notes: Proof print made in the field by

Curtis.

Provenance: Gift of Valerie Burton \& David

Milman, 1985

Subject: Portrait

Related Object in NAI: Negative basis for Volume 10, pg. 14 and Portfolio 10, Plate

322

Curtis made cyanotypes as proof prints while in the field. The cyanotype process required few chemicals and needed only sunlight to make a print, thus it was easy to make while camping. Then he would send the prints with his notes back to his darkroom assistant, Adolph Muhr, in Seattle. A skilled photographic printer, Muhr worked magic with some of Curtis's images: turning blurs into definable objects. This negative is unique in that it was used twice in The North American Indian: cropped to a full body shot for the volume print on page 14 of Volume 10, then cropped to just the face for the portfolio. 


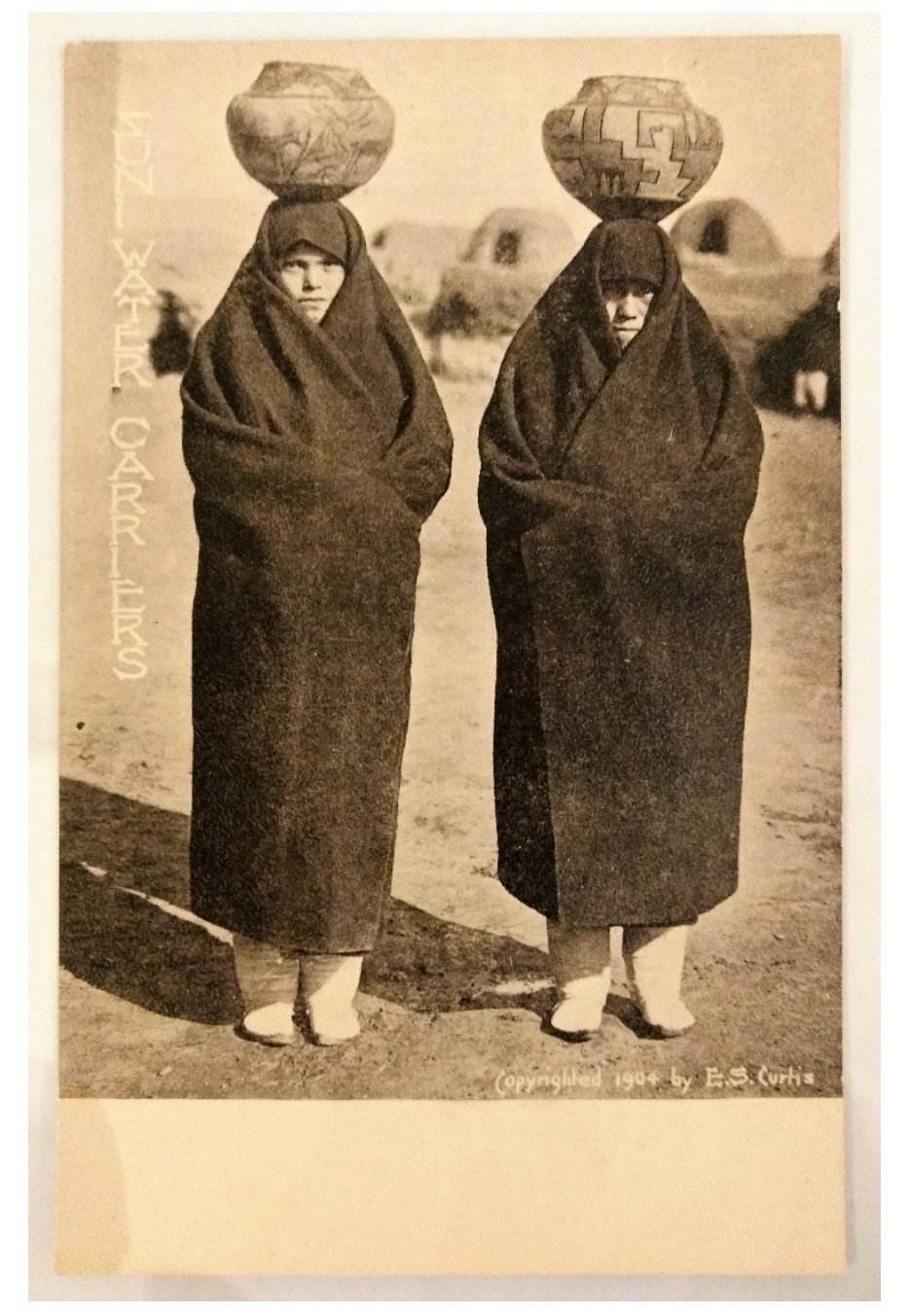

Accession Number: 2007/110

Photographer: Edward S. Curtis (1868-

1952)

Title: Zuni Water Carriers

Date: Negative: 1904

Medium: Half-tone postcard

Dimensions: $13.4 \times 8.5 \mathrm{~cm}\left(5 \frac{1}{4} \times 3\right.$ 3/8 in)

Notes: None

Provenance: Anonymous donation, 2007

Subject: Genre Scene

Related Object in NAI: Same as

photogravure in Volume 17, pg. 110

This is one of many images of water-carrying. Curtis photographed many women from the desert tribes

in the Southwest gathering and carrying water in pots that they would then balance on their heads.

Curtis sold postcards like this one to finance his fieldwork. The postcards were printed on textured paper stock with titles in calligraphy written vertically down the side. Postcards were popular in the early twentieth century and appealed to a wide audience. Before 1907, only the address was allowed on the back of a post card, so a white portion was left at the bottom of the front of the card for messages. This card was probably made between 1904 and 1907. 
Accession Number: 10204

Director: Edward S. Curtis (1868-1952)

Title: In the Land of the War Canoes: Kwakiutl Indian Life on the Northwest Coast

Date: 1914, restored 1974

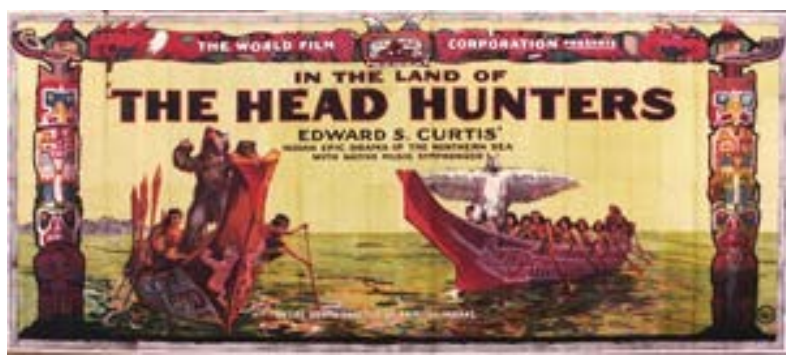

Medium: $16 \mathrm{~mm}$ (black-and-white, optical sound) Running Time: 43 minutes

Notes: This is the restored version of In the Land of the Head Hunters. Screened four times: 1977, 1980, 1982, 1993. Condition: Heavy scratching throughout.

Provenance: Purchased by the AGO, 1974 or 1975

Constituent: Film Restoration: Bill Holm \& George Quimby

Related Object in NAI: Volume 10 The Kwakiutl.

In the Land of the War Canoes follows the story of Motana in his quest to prove his love for Naida. He faces many challenges, like hunting and killing a whale, but wins over Naida. Disaster strikes when the village is attacked by a sorcerer and his brother. Naida is taken captive and Motana is left for dead. Naida sends a message to Motana and he rescues her. The sorcerer and his brother are killed in a final battle.

Image: Lithograph broadside for Edward S. Curtis's film In the Land of the Head Hunters, 1914. (C) 1914 H. C. Miner Litho. Co., N.Y. Courtesy of Bill Utley. http://www.getty.edu/visit/events/head_hunters.html ?cid=egetty078. The text reads, "Indian epic drama of the northern sea with native music symphonized. Entire drama enacted by primative[sic] Indians." 


\section{Major Holdings of Curtis's Work}

Curtis's work can be found in almost every major institution in North America. These holdings can range from a few photogravures to a hundred prints or a complete set of The North American Indian. As noted elsewhere in this thesis, approximately 300 complete sets of the volumes were printed. Only about 125 of these sets remain intact and are mostly located in public institutions such as university libraries and rare book collections. This means that about 175 sets were unbound and sold off in pieces. With about 2,200 photogravures per set, 175 unbound sets makes 385,000 original prints potentially on the market or located in other institutions. In addition, the original copper photogravure plates were used to make an unknown number of restrikes in the 1970s. The plates are still held privately and their provenance can be traced back to the Morgan Library who sold them in 1935 to Charles Lauriat.

Major holdings of Curtis's work can be found at the Library of Congress, the Peabody Essex Museum in Salem, MA, and Indiana University. Acquired from copyright deposit from 1900 through 1930 directly from Curtis, the Library of Congress collection consists of 2,400 gelatin silver prints made from the original glass plate negatives. About two-thirds of these prints were not published in The North American Indian, giving the collection a unique glimpse into Curtis's work. The Peabody Essex Museum acquired its Curtis collection in 1906 from Charles Goddard Weld who bought the 108 prints at one of Curtis's fundraising exhibitions. The collection consists of platinum and gelatin silver prints known as "master prints." Indiana University houses a collection of 276 wax cylinders made in the field by Curtis. The recordings of Native American music were all made between 1907 and 1913.

There are two notable private collections of Curtis material: the Charles Lauriat Archive now based in Southern California, which consists of the copper plates and materials sold to Charles Lauriat by the Morgan Library, and the extensive collection of Christopher Cardozo based in Minneapolis, MN. The 
Charles Lauriat Archive has changed hands several times since the 1970 s. A group of investors bought the plates form Lauriat Bookstore in 1971 and undertook making new prints from the copper plates but the venture ended in bankruptcy. ${ }^{1}$ The copper plates are still held privately but a portion of the collection was donated to the National Museum of the American Indian, New York in 1985. Cardozo regularly publishes books using his collection and has recently undertaken a project to re-publish The North American Indian. Over the last four decades, he has amassed a collection considered to be the "world's largest and most broad-ranging." ${ }^{2}$ Cardozo has also recreated Curtis's goldtone process, also known as orotone or "Curt-tone."

Sets of the entire 20 volumes can be found at Northwestern University, the Morgan Library, the University of Washington, the University of Denver, University of Oregon Special Collections, Seattle Public Library, Spokane Public Library, and the University of Wyoming, among others. Northwestern University digitized their volumes and provided free online access to the entirety in $2004 .^{3}$ The Library of Congress holds a 1970 reprint edition of the set in its Prints and Photographs Division. The Morgan Library holds set \#1 of the original planned edition of five hundred. The University of Oregon Knight Library Special Collections holds the Japanese tissue printed set that belonged to Curtis.

\footnotetext{
${ }^{1}$ Cardozo 179

${ }^{2}$ https://edwardcurtis.com/christopher-cardozo/

${ }^{3}$ http://curtis.library.northwestern.edu/aboutproject.html
} 


\section{Further Reading}

Cardozo, Christopher, ed. Edward S. Curtis: One Hundred Masterworks. With contributions by A.D. Coleman, Louise Erdrich, Eric J. Jolly, and Michael Charles Tobias. New York: Delmonico Books / Prestel, 2015.

Coleman, A.D. "Edward S. Curtis: The Photographer as Ethnologist." In Depth of Field: Essays on Photography, Mass Media, and Lens Culture, 133-158. Albuquerque: University of New Mexico Press, 1998.

Curtis, Edward S. The North American Indian: Being A Series of Volumes Picturing and Describing the Indians of the United States, the Dominion of Canada, and Alaska. 20 vols. Cambridge, MA / Norwood, MA: printed by author / University Press / Plimpton Press, 1907-1930. http://curtis.library.northwestern.edu/index.html.

Davis, Barbara. Edward S. Curtis: The Life and Times of a Shadow Catcher. San Francisco: Chronicle Books, 1985.

Egan, Timothy. Short Nights of the Shadow Catcher: The Epic Life and Immortal Photographs of Edward Curtis. New York: Houghton Mifflin Harcourt, 2012.

Gidley, Mick. Edward S. Curtis and the North American Indian Project in the Field. University of Nebraska Press, 2003.

Gidley, Mick. Edward S. Curtis and the North American Indian, Incorporated. Cambridge: Cambridge University Press, 1998.

Graybill, Florence Curtis, and Victor Boesen. Edward Sheriff Curtis: Visions of a Vanishing Race. New York: American Legacy Press, 1976.

Holm, Bill and George Irving Quimby. Edward S. Curtis in the Land of the War Canoes: A Pioneer Cinematographer in the Pacific Northwest. Seattle: University of Washington Press, 1980.

Lawlor, Laurie. Shadow Catcher: The Life and Work of Edward S. Curtis. New York: Walker, 1994.

Lyman, Christopher M. The Vanishing Race and Other Illusions: Photographs of Indians by Edward S. Curtis. New York: Pantheon, 1982.

Sutnik, Maia-Mari. Edward S. Curtis: Photographs of Indians. Art Gallery of Ontario, 1988.

Touchie, Rodger D. Edward S. Curtis: Above the Medicine Line; Portraits of Aboriginal Life in the Canadian West. Vancouver, BC: Heritage, 2010.

Zamir, Shamoon. The Gift of Face: Portraiture and Time in Edward S. Curtis's The North American Indian. Chapel Hill, NC: University of North Carolina Press, 2014. 


\section{Appendix A: Volumes of The North American Indian}

List of volumes in The North American Indian

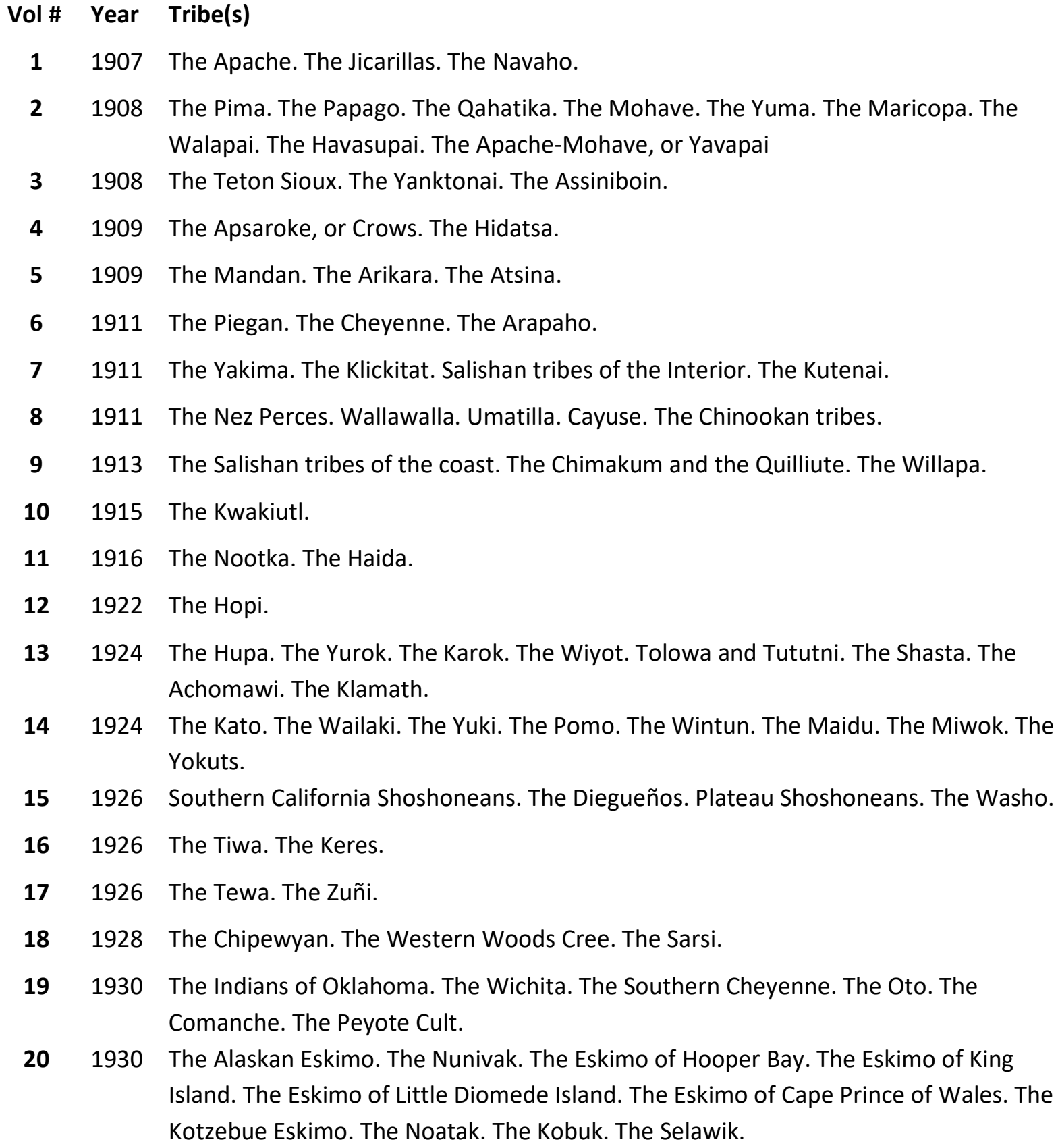

141924 The Kato. The Wailaki. The Yuki. The Pomo. The Wintun. The Maidu. The Miwok. The Yokuts.

151926 Southern California Shoshoneans. The Diegueños. Plateau Shoshoneans. The Washo.

161926 The Tiwa. The Keres.

171926 The Tewa. The Zuñi.

181928 The Chipewyan. The Western Woods Cree. The Sarsi.

191930 The Indians of Oklahoma. The Wichita. The Southern Cheyenne. The Oto. The Comanche. The Peyote Cult.

201930 The Alaskan Eskimo. The Nunivak. The Eskimo of Hooper Bay. The Eskimo of King Island. The Eskimo of Little Diomede Island. The Eskimo of Cape Prince of Wales. The Kotzebue Eskimo. The Noatak. The Kobuk. The Selawik. 


\section{Appendix B: John Andrew \& Son Sample Book of Photogravures}

The text included here explains the process used to produce the photogravures in The North American Indian. John Andrew \& Son was a master engraving company that made the prints in Volumes 1-11. The prints for Volumes 12-20 are credited to Suffolk Engraving Company, which was the parent company of John Andrew \& Son. The reason for the change is unknown, but the change occurred during a six-year break in publishing between Volume 11 (1915) and Volume 12 (1922).

John Andrew \& Son Sample Book of Photogravures. 1913. David A. Hanson Collection of the History of Photomechanical Reproduction. Sterling and Francine Clark Art Institute, Williamstown, MA. http://maca.contentdm.oclc.org/cdm/ref/collection/p1325coll1/id/3743.

In presenting this selection of reproductions by photogravure of a varied line of subjects, we desire to call attention to the superiority of this process to any in existence at the present day for the reproducing of pictorial or commercial subjects.

Its place, as regards the reproduction of paintings and book illustrations, needs no comment, and its use, in presenting high-class goods to select lists of patrons, presents possibilities which can be readily appreciated from the samples shown in this booklet. Its distinctive quality suggests the same quality in the goods advertised.

The wide range of selection of paper and the method of printing insure a result, in the final product, absolutely equal to the first finished printed reproductions. It is process of plate-making and printing that at once lifts a piece of advertising matter out of the ordinary.

We respectfully solicit your correspondence, or an invitation to confer with you, regarding the production by photogravure of any work you may have in mind. Following is a brief description of the plate-making and method of printing by this process. 


\author{
John Andrew \& Son \\ Department of the \\ Suffolk Engraving \& Electrotyping Co. \\ 394 Atlantic Avenue \\ New York Boston, Mass. Providence
}

Photogravure

Photogravure has been justly called the aristocracy of the photographic reproductive processes. It is an intaglio process having every advantage of photographic accuracy, and the depth and richness of a steel engraving or an etching. It is printed in exactly the same manner as the latter, from a copper plate, the surface of which is protected with a delicate coating of steel. It must be borne in mind that it is exactly the opposite from relief or letterpress printing, inasmuch as the paper is squeezed into depressions in the plate, which are filled with ink, instead of taking the ink off of a surface which is covered with ink.

The process of plate-making is as follows: On a highly polished copper plate is deposited a very fine dust of bitumen, which is a resinous powder. This is subjected to a proper degree of heat which melts the fine particles of the powder to a certain extent, and gives a plate covered with a very fine resinous grain. This copper plate is then coated with sensitized gelatine[sic] in practically the same manner as a photographic dry plate is made. A regular toned negative, of the same nature as would be required to make a good print on photographic paper, is made, and from this a positive of the size called for in the final photogravure print. This positive is of the same nature which we see in a window transparency or lantern slide.

The sensitized grained copper plate is then placed in contact with the positive in a printing frame and placed in the proper light, exactly as if we were making a photographic print on paper. The action of the light on the sensitized grain on the copper hardens it in different degrees, according to the 
different tones in the positive. The highlights or transparent parts of the positive all the strongest action of light, which hardens the particles of the grain protecting these parts of the plate to the greatest extent, so that when we come to etch the plate the acid has very little chance, or none at all, to disturb the surface of the copper. The shadows being acted upon less, or not at all, leaves the copper in different degrees of protection, and gives the acid a chance to bite into the copper to a greater or less extent, as called for in different values of shadows or blacks in the subject.

We must bear in mind all the time that this operation is exactly the opposite from that which we wish to obtain in a half-tone or relief plate, as we wish the lights to be solid metal and the darks to be depressions in the metal, hence the use of a positive instead of a negative. When we get a proper print on the copper and have washed away the superfluous gelatine[sic], we have a plate which is protected in varying degrees in accordance with the tones of the subject.

The next step is to protect all the surface of the copper outside the boundaries of the picture, as this must be perfectly polished copper. This is painted over with an asphaltum varnish, as well as the back of the plate, and we are ready to etch. The etching is done with perchloride of iron solution as an acid, and the result is then dependent on the skill and judgment of etcher. The plate is then thoroughly cleaned, and we have in the darks of the picture a roughness of copper, but extremely fine in texture, and this roughness or grain smoothing itself out through the different tones until, when we get to where we wish white paper, we have no grain at all, but smooth polished copper.

Any defects are corrected, or minor changes are now brought about, in the same manner that a steel engraver or etcher would manipulate a steel or copper plate, and we are ready for a proof. The plate is put on the bed of the press, which is flat, and kept slightly heated, and the ink applied by a hand roller in quantity sufficient to thoroughly fill all the interstices of the grain in the plate, and the excess wiped away with cloth, and afterward with the bare hand. The paper, which can be of almost any 
nature, except coated or highly sized, is dampened and laid on the plate. The bed is then run under a roller covered with a woolen blanket, with considerable pressure, which squeezes the paper into the filled-in grain, and the result is a print which in depth of shadow and beautiful gradation, and softness of tone, cannot be equaled by any other photographic reproductive process.

As soon as this proof is considered approved, and we are ready to print the edition, the plate is electro-plated with a very thin coating of steel which in no way affects the quality of tones, but protects the delicate grain which would soon wear away, as the copper itself is too soft to stand the continued wiping and general wear of printing.

Photogravure has been used to the greatest extent for high-class book illustration and the reproduction of paintings for framed pictures. It has come into use recently, however, along commercial lines where the edition has not been too large, and many exquisite booklets, covers, menus, announcements, etc., have been produced. These have the quality and value of steel engravings, but are much more artistic and yet not so prohibitive in regard to expense as the latter.

The impression of quality is heightened when the photogravure is printed on one of the many imported hand-made papers from Japan, Italy, France, Spain and England. 


\section{Appendix C: Life and Career of Edward S. Curtis}

1868 Edward S. Curtis born in Whitewater, Wisconsin

1887 Curtis moves to Washington Territory

1891 Curtis buys into a photographic studio with Rasmus Rothi in Seattle, WA

1892 Curtis leaves his partnership with Rothi and begins a new studio with Thomas Guptill. This studio becomes known as the premier photographic portrait studio of Seattle. Curtis marries Clara Phillips.

1895 Curtis photographs Princess Angeline, daughter of Chief Sealth.

1896 Curtis and Guptill win a bronze medal at the National Photographers Convention in Chautauqua, New York.

1897 Curtis and Guptill part ways, leaving Curtis the sole owner.

1898 Curtis rescues a group of scientists climbing on Mount Rainier, including George "Bird" Grinnell (chief of U.S. Biological survey), C. Hart Merriam, and Gifford Pinchot (chief of U.S. Forestry Department).

1899 Curtis accompanies the Harriman Alaska Expedition as the official photographer.

1900 Curtis and Grinnell travel to Montana to photograph the Piegan Sun Dance ceremony. Around this time, the Curtis Studio starts producing "Curt-Tones."

1904 Curtis meets and photographs Theodore Roosevelt and his family after winning the Ladies' Home Journal contest for "The Prettiest Children in America."

1905 Curtis holds fundraising exhibitions along the East Coast.

1906 J.P. Morgan becomes the financial backer for The North American Indian project.

1907 The first volume of The North American Indian is published. Through 1910, Curtis balances fieldwork, fund-raising, and preparing of The North American Indian.

1911 A whale slaps Curtis during the filming of a Kwakiutl whale hunt and breaks his hip. A fundraiser called "The Curtis Picture Musicale" is performed in eastern cities.

1912 Curtis founds a film company to produce a documentary of Native life called In the Land of the Head Hunters. Curtis's long time dark room assistant Adolph Muhr dies.

1913 J.P. Morgan dies but funding for The North American Indian continues.

1914 In the Land of the Head Hunters premieres in New York City.

1916 Publication of The North American Indian is suspended as the U.S. enters World War I. Clara, Curtis's wife, files for divorce. 
1919 Curtis and his daughter, Beth, move to Los Angeles where Curtis works as a portrait photographer and movie camera operator. He travels to the Hopi reservation to continue fieldwork.

1922 Curtis revives The North American Indian and travels to Northern California for fieldwork.

1927 A trip to Alaska concludes the fieldwork for The North American Indian.

1928 Curtis signs over the copyright of The North American Indian and all of his images to the Morgan Estate.

1930 Curtis publishes the last two volumes of The North American Indian and suffers an exhaustioninduced breakdown. At this point, the project generates little interest and sinks into obscurity.

1935 The Morgan family sells the materials from the project to Charles Lauriat Company, a rare book dealer in Boston.

1952 Curtis dies at age 84 of a heart attack at the home of his daughter Beth. 


\section{Appendix D: "Photography" by Edward S. Curtis}

Edward S. Curtis, "Photography." Western Trail, January 1900: 186-188.

This Department will be of especial value to Amateurs. "He is the greatest artist, then, whether of soul or pen who follows nature."

Some time ago I was asked what would be the best book or books for a beginner in outdoor photography to study. My reply was that the most real help would be from a work on sketching from nature.

I have spent a couple of years since trying to better my personal work, and I am still of the same opinion that for outdoor work this is the best advice.

Following this same suggestion George B. Sperry, of Toledo, O., in an address before the National Photographic convention said:

I know of no greater need than the need of better art education. Important and wide-spread as this need is, I cannot approach the subject without a feeling that I ought to apologize for it. We have been laughed at for calling ourselves photographers, when, as alleged, we know nothing of the rules of art. We have been told to build our pictures on pyramidal lines, to balance our diagonal lines, to be careful where we placed our horizontal lines and to be sparing of our upright lines. Are we to be blamed if we conclude that art is to be measured with a foot rule?

We have seen photographs praised for their artistic merit which to us seem flat, stale and unprofitable. We have had our own efforts to be artistic frowned upon by our patrons, and these efforts have seemingly produced so little that was of lasting benefit that some of us have grown a little weary of the word and are wondering if the results are worth the efforts. When we reach the conclusion we are ready for the next step. 
Important as are the rules of perspective and composition, they are but tools. Art could not exist by them alone. Art is feeling. As Longfellow so beautifully says, "Art is the child of nature. Yes, her darling child, in whom we trace the features of the mother's face; her aspect and her attitude; all her magnificent loveliness chastened and subdued into a more perfect grace, and with a human sense imbued. He is greatest artist, then, whether of soul or pen, who follows nature. Never yet man, as artist or artisan, pursuing his own fantasies, could touch the human heart or please or satisfy our nobler needs, save he who sets his willing feet in nature's footsteps, light and fleet, and follows, fearless, where she leads."

What is man that he should have these aspirations? Again the poet speaks:

"What are, whence came we?

Are we but a state of shifting matter built into a frame

Which grows and changes, yet remains the same, or seems to?

Does our thought, our love, our hate

Depend upon secretions? And does Fate

Stand at the helm and steer an unmanned boat

Midst rocks of chance? Or is there that within

Which is not matter? Calling from the dark

I am, I will, I suffer, and I sin.

I know of nothing save that only I feel all things within myself.

If, then, I die 
Nature itself may pass. I cease to be

And all is blotted out which lives in me.

I feel I cannot die, for life I cry."

Here art is born. It is this striving of something better that begets the art feeling. No man can say, "I have no such feeling." Whether it be a spark or a flame depends upon ourselves. We are the creatures of environment only so far as we choose our environment.

In criticizing a picture an artist will say, "I feel these lights are too braid," or, "I cannot feel his interpretation." Try your next composition with more regard to feeling and less thought of the lines. You will soon find that the lines are apparently taking care of themselves. No master has ever lived who has not at some time broken the rules of perspective or composition. But art will stand impregnable.

When I say that we should study for a greater art education I do not mean that we should try to make our work like a brush or pencil artist. Photography is one of the greatest art sciences and is able to stand for itself. Let us study light and shade, composition and perspective, both as it is seen in nature and in the work of the masters, not to copy but to learn. Once we know the true rules of art it will soon be shown in our work.

The Photo American for December has an article entitled, "Diseased Photography," by Edward W. Newcomb, which is very much to the point:

People are making stuff they call new-school photography, which they and their worshippers marvel at for the most unsensible, blind reason that they can't understand it; it contains considerable evidence of genius, but no merit. It is not like old-fashioned photography, hence it is the "new school." It is so impressionistic that one don't know what to make of it, and the only impression a sane man receives is that rather more than the usual possible number of mistakes happened from the conception 
of the exposure to the last operation, and that the unlucky devil who did all this tommy-rot has somehow got into good society before he was taught the way to behave, or ere he even gained such discretion as would help him to hold his tongue and restrain himself. Don't admire his stuff, much less strive to unlearn enough to be able to imitate him, for, if your own reason and sense of the appropriate tells you that such work is not fish, flesh or fowl, it shall also counsel you to drive this pretender away, lest he harm you. Some impressionistic paintings are clever, admirable, and are pictures worth owning, but these the paintings, remember; not a bad hodge-podge of indecision, made with camera, chemicals and a deranged mind, possibly aided and abetted by a shoebrush. These horrid imitations of paintings are neither photography nor art, and there can be no reason for their being. If a man exhibits an enlargement from an under-timed negative, which, by chemical treatment, has been turned into a brownish yellow or sickly blue or greenish red with no pure white high lights, no evenness of color (erroneously called tone) and a suppression of detail obtained by printing on rough canvass on coarse cloth before the enlarging easel, if he exhibits one of these abortions to you as "new school" photography, just use your own sense - not his estimate - in criticizing the thing. There never was much of an old school in photography as there has been in painting; it was, and is till, experimental groping about for some true photography of a high order, and to admit that it ever became of consequence enough to entitle it to our consideration as a "school," would be wrong indeed; call it our kindergarten, and the so-called old school is better described. Well, then, our art photography having advanced far beyond the kindergarten stage and there having yet been no school, why, of course, we have brought photography into a more advanced shape, and are ready to acknowledge that there is at last a settled school; broad enough in its conception and ambition to satisfy all but faddists and extremists. But this school is not an exponent of diseased photography; we have seen that the men in this school are healthy in ideas and work, and that these absurd people of the "new school" are not doing it the slightest harm. In helping healthy, artistic photographers, the influence of this somewhat conservative advanced 
kindergarten is very great, and if those of us who quite properly seek enlightenment want help, it is from its adherents that I would ask all to seek light, not from an absurd clique whose ambition to be talked of is worthy of a better cause. I am sorry to chronicle that one of the juries on a recent important exhibition accepted a picture (?) which, from the maker's description, was produced totally through effort to save a piece of his work, which, to use his own expression, was "rotten" to begin with, and worse when he finished his ill-understood experiments on it. Think of such a state of affairs! I am glad it has happened for one reason, if no other, that we surely have seen a sickening amount of this stuff, and will revolt from the ranks of any set who believe or try to believe that it is meritorious of our praise and admiration. It has been coming on for some time, but I feel sure that such nausea has at last resulted as will effectually kill it and forbid it a moment's further notice from true photographic picture makers. 


\section{Appendix E: "The Amateur Photographer" by Edward S. Curtis}

Edward S. Curtis, "The Amateur Photographer." Western Trail, February 1900: 272-274.

The editor of this department will, for a time at least, attempt to criticise photographs mailed to him for that purpose. Critcism will be published, giving initial of maker. Those wanting photographs returned by mail should enclose stamp for that purpose.

There is a great army of button pushers, and but few are amateur photographers. Quantity rather than quality seems to be the aim of the multitude. This is a good thing for the stock dealers, but does not raise the standard of your work.

The season is now approaching when you will prepare for the year's work. Make up your mind that you will make a certain number of pictures, let it be one or twenty; think well over it and study the subject. A good way to start your thoughts in the right channel is to take some finely illustrated book, look it over carefully, and let the pictures suggest some other picture; then search for the spot that you think will make the picture that you have in mind. Study this in different lights and at different times of the day; see what you can leave out and try and determine what can be included. Study every line of your subject, and at last, if you think the subject worth it, expose a plate, develop and make a proof. Now turn critic and study this. If it is "weighed and found wanting," drop the negative on the floor and start in again, as you know that this is to be a picture and not snap shot. Bear in mind that you are an amateur and are making the picture for pictures' sake. With the professional it is different. In his case some one wants a picture of a certain subject, to be done at a certain time. His business is to get a good photograph under any and all conditions. Please notice that I said good photograph and not good picture. 
Many artists claim that a photograph cannot be a work of art. However, I do not think the most radical of them can deny that a photograph can show artistic handling and feeling. After all, it is the finished picture that hangs upon our wall, and not the implements with which it is made.

While you are working on this one picture that is to show the best that is in you, you will be making others. Let me urge you to make a specialty of some one thing. This is a day of concentration, and to make a showing you must be a specialist, and there are an endless number of subjects that can be followed out. Let me mention a few of the many subjects. Do you know of the series of photographs of the wild flowers of our state, or of the magnificent forests of Washington?

Then what a collection of marine pictures could be made on the Sound, trout fishes and trout fishing - these are all subjects which are well worth one's time. Again, fishing on the Sound.

What could cause more exclamations of delight than a portfolio of dog and cat pictures? Select a subject that you think will interest you and determine to work on it the coming season, and by the autumn you will just begin to see what is in it and to feel that you have accomplished something. Soon you will begin to hear that "Mr. Brown had the most beautiful set of dog pictures I ever saw."

Remington made his reputation drawing horses. Had he spent his time on a variety of subjects, the chances are that no one would know who Remington is today. Whatever you take up, always keep in mind these two words - Simplicity and Individuality - and remember that simplicity does not mean tameness. A great artist has said "the great requisite of taste is simplicity." Do not seek to astonish, but to please. The beating of a bass drum would attract our attention as quickly as the finest melody, but would not please. In the same way spectacular pictures do not make pleasing pictures. Try to make your work show individuality, or in other words, make it look yourself; let it show that you have put part of your life in it. 
I have made no mention of the technical part of the picture or of the chemical work to produce it. The first is a subject that would be a lengthy discussion and would be better treated by itself.

A word about developing. Developing and printing formulas are found in every box of plates and paper. What I have tried to do is to get you to put your best into the making of a picture and a striving for better work.

Notes

If you are contemplating a trip to Alaska or the mountains, do not fail to pack your plates or films in water-tight packages. This precaution would have saved many camera workers great disappointment. A notable case of this was the ascent of Mt. St. Elias by the Italian expedition. Think of the loss to the world of all the photographic work of that trip.

"It is well-known fact that cold developer will yield thin and apparently under exposed negatives. The temperature should therefore be raised to 75 to 80 degrees F. either by adding warm water to the concentrated developer or by placing the bottle for a while into a vessel containing warm water. The hypo-solution when very cold fixes slowly, and should be warmed to a temperature of 60 to 70 degrees F. Care should be taken not to transfer the negative from the warm fixing solution to very cold washing water, as frilling or a total separation of the film from the glass might result." - (Snap Shots.)

I have also found that it was necessary to use a stronger developer in a cold climate as well as warming it to some extent. Also that in the mountains the altitude seems to affect the developer so that I had to use a very concentrated developer. This may have been wholly due to the temperature, but it seems to me that the altitude affected as well. 
Another precaution for one who is starting for the mountains is to take among the supplies a piece of mat celluloid to replace the ground glass in case it should be broken. It makes a much more satisfactory ground glass than a piece of brown paper covered with butter.

"Squeegeeing Prints. - There are many who prefer the highly polished surface in their mounts. This may be made highly satisfactory from their point of view by squeegeeing the print on a waxed 'ferrotype' plate. Take a piece of firm textured paper, slightly larger than the squeegeed print, and coat with a stiff corn starch paste, and place this on the back of the print, pressed into perfect contact. Now coat the back of this with LePage's glue and allow it to dry. When dry, strip the print from the plate and trim it. Now dampen the mount evenly with a wet sponge and quickly lay in position. Now place a 'bonedry' blotter on the print and press firmly into contact." - (Philadelphia Record.)

"If enlarging on bromide paper it must be borne in mind that, all things remaining the same, the exposure varies as the square distance between the lens and the film, so that it is longer the more times we wish to enlarge." - (W. K. Burton, C. E.)

Edward S. Curtis, "The Amateur Photographer." Western Trail, April 1900: 379-380.

\section{A PLEA FOR BETTER WORK.}

Was your work of 1899 superior to that of 1898 ? If so, in what way; and if not, what excuse can you give for not improving the quality of your work? Do a little serious thinking and see if you do not think that you can improve the quality of your work during the coming year. Study the photographs of the recognized workers and the reproductions of the many landscape painters. Learn to criticise. If you like a picture, study it over part by part and decide why you like it. It is probably as hard to criticise a good picture as it is to make it. 
Now, let me suggest in landscape work, the early morning is the time of all times to secure a fine picture, the light is low, bringing every object out in bold relief. In the mountains the morning is almost the only time the atmosphere is clear and free from the blue haze. Every crag and peak casts long shadows, causing the whole to stand out in rugged grandeur. Good pictures are generally the result of long study rather than chance. I have spent four summers on the slopes of Mount Rainier trying to photograph it and its surroundings in the many lights and atmospheric moods, and a number of the pictures I worked up in my mind the first season are not made yet. I have not been able to be at the right spot at the right time of day and the proper condition of the atmospheric effect. Perhaps I shall never go back to my beloved mountain of mountains to make these pictures I have in my mind, but the study of the subject has helped me to compose other pictures.

I advise any one who is making pictures to keep a note book for that purpose and whenever a good subject occurs make a note of it.

In arranging a landscape without figures, remember a bold foreground with masses of shadows in a strong central light goes a long way in making a pleasing composition. When I said masses of shadows, I did not mean a large black blank space with no detail to relieve it; but rather masses of shadows in which there are lights.

Study Dore's illustration of Dante and see how he lights up his shadows. One which particularly illustrates this is the plate illustrating Canto XII., lines 58 and 59:

“One cried from far: 'Say, to what pain ye come, Condemned, who down the steep have journeyed."'

Prof. S. Rufus Mason says: “Daguerre jogged the world into a new path; the eyesight of the people was sharpened, their intellects were brought to a focus and were thrown upon nature, the 
fountain head of all knowledge; the reflection back upon their minds gave a new understanding, a command of thoughts, of ideas, a positive knowledge of size, shape, light and shade, distance, foreshortening, perspective, unity, congruity, and placed every observer upon a pinnacle from which to survey the world, hitherto absolutely unattainable. Every one became an embryo artist, and as this new faculty did not interfere with the power of speech, but seemed to give it new and advanced ideas to work with, the powers of description, so lacking in many, began to feel the influence of the hour, and good drawings, good descriptions grew so fast that now, at this day, there are many persons who are first-rate writers on subjects not often even considered by those previous to Daguerre.

"A man who can see no faults can see no beauties. His ideas, his faculties, his ability to think, his power of expression, even, seems to lie dormant; he is a stick, a log, built to be an active, living member of society; he is a mere clod; he has innately all the machinery of mind necessary to constitute him a 'man of mark,' but he has no incentive, no stirring influence to rouse his faculties; he is a mere lucifer match - of no earthly use till some one rubs his back.

"Education is a cultivation of the faculties with which we are amply supplied. Curiosity is the most powerful incentive of the human mind, and the boy who is constantly asking questions proves his possession of a mind which demands education and will have it, and the parent who is able, by the tendency of his replies, to lead the boy to the truth, will never feel that there is any danger of a wicked tendency.

"Let every child learn observation - drawing - by directing the mind to minutiae - best develops that faculty. Pictured illustrations are now so common that criticism of art is universal; and as a picture tells more in a few square inches than whole pages of letter-press can, let us encourage pictures, the power to produce them, and the ability to discuss them fairly and artistically: I give Daguerre the whole credit of inaugurating this great boon to mankind." 
Edward S. Curtis, "The Amateur Photographer." Western Trail, May 1900: 468-469.

I have urged you time and again to make fewer pictures and better ones. Now, let me illustrate by telling you of an amateur friend of mine, who is a very modest and unassuming young fellow and does not like any unnecessary prominence, hence I shall refrain from using his name, much as I should like to tell you who he is and what a fine fellow he is in every way. Enough for our purpose is the fact that he is one of the most careful photographers on the coast, and thoroughly - there, I was going to use that worn out word "artistic," for which I beg his and your pardon, and will say that he has good taste and ability to select the right spot for a picture, and his technique is always good.

With all these qualifications, he is a man of means and comparative leisure; that is, he spends at least half of each year wandering about the world to see what is to be seen and to secure such pictures as he can. A couple of days ago he called on me to say Kla-how-ya; he was on his way home, after having spent the winter in China and Japan, which countries he declares are the most picturesque in the world. I questioned him as to the photographic results of his trip to the Orient and the past year as a whole. His reply was that he had exposed about six hundred plates during the year and had about twenty pictures that he considered good enough to show his friends. Amateur workers, stop a moment and think. Here is a photo artist of means and leisure, able to travel to the utmost corners of the earth, whose work is chemically and technically good, who has exposed on an average two plates a day for a year, and has but twenty pictures which he considers good enough to show his friends.

Some of you think this is too high a standard, but I think you would change your mind if you could see those twenty pictures.

Let every one's work show individuality. Try to make it pronounced enough that a friend could pick up one of your pictures anywhere and know that it was yours. Some one will say that landscapes all look alike and the photographer cannot put enough of himself into his work to show his character. I 
believe that it can be done. After looking at a dozen of Horsley Hinton's photographs any lover of pictures can tell them instantly.

The year 1900 will see a decided change in high-grade photography, and the hanging committees of the different salons are demanding a better class of pictures. The Chicago salon has rejected work hung at the Philadelphia and other Eastern exhibitions. This goes to show that only the best class of work will meet with popular acceptance.

The National Photographers' Association of America has changed its plans entirely. Formerly the whole has been divided into four divisions, photographers in each division competing with work in his division only. This year there is to be no divisions, and any one competing competes with those from all parts of the United States.

Another and a greater change is that there is to be a hanging committee, who will reject all pictures not having special value, or in other words, the mere fact that a picture passes the hanging committee attests its value, and any one securing a medal at the coming convention can well be proud of it.

How many of The Western Trail readers are going to try for one or more of those prizes offered by the Ladies' Home Journal? I should like to see more of these prizes won by workers in our state than why we cannot do this. Let every one take this up and do their very best. 


\section{Bibliography}

Adam, Hans Christian, ed. Edward S. Curtis. Taschen, 2012.

Andrews, Ralph W. "He Knew the Red Man: Edward S. Curtis, Photographer." Montana: The Magazine of Western History 14, no. 2 (1964)

Arrivé, Mathilde. "Beyond True and False? The Artificial Authenticities of Edward S. Curtis: Responses and Reactions." Translated by John Tittensor. Études Photographiques 29 (2012). Accessed 9 May 2017.

Billings, Maria. "A Contextual Analysis of the Photographs in Edward S. Curtis's The North American Indian." Master's thesis, Western Washington University, 1989.

Brayham, Angela. "Art of Ethnography: A Critical Analysis of Edward S. Curtis's The North American Indian." Thesis/diss., 1992?

Brown, Joseph Epes. The North American Indians: A Selection of Photographs by Edward S. Curtis. New York: Aperture, 1972.

Brown, Wendi Starr, and Tamara Northern. To Image and To See: Crow Indian Photographs by Edward S. Curtis and Richard Throssel, 1905-1910. Hanover, NH: Hood Museum of Art, Dartmouth College, 1993.

Cardozo, Christopher. "A Collector's Guide." Christopher Cardozo Fine Art. Accessed June 28, 2017. https://edwardcurtis.com/a-collectors-guide/.

Cardozo, Christopher, ed. Edward S. Curtis: One Hundred Masterworks. With contributions by A.D. Coleman, Louise Erdrich, Eric J. Jolly, and Michael Charles Tobias. New York: Delmonico Books / Prestel, 2015.

Cardozo, Christopher. Edward S. Curtis: The Great Warriors. New York: Bulfinch, 2004.

Cardozo, Christopher. Edward S. Curtis: The Women. New York: Bulfinch, 2005.

Cardozo, Christopher. Sacred Legacy: Edward S. Curtis and The North American Indian. New York: Simon \& Schuster, 2000.

Coleman, A.D. "Edward S. Curtis: The Photographer as Ethnologist." In Depth of Field: Essays on Photography, Mass Media, and Lens Culture, 133-158. Albuquerque: University of New Mexico Press, 1998.

Curtis, Edward S. "The Amateur Photographer." Western Trail, February 1900: 272-274; April 1900: 379380; May 1900: 468-469.

Curtis, Edward S. Letters to Harriet Leitch. 1948-1951. Edward S. Curtis Digital Collection. Seattle Public Library. http://cdm16118.contentdm.oclc.org/cdm/landingpage/collection/p16118coll16.

Curtis, Edward S. The North American Indian: The Complete Portfolios. Taschen, 2015. 
Curtis, Edward S. The North American Indian: Being A Series of Volumes Picturing and Describing the Indians of the United States, the Dominion of Canada, and Alaska. 20 vols. Cambridge, MA / Norwood, MA: printed by author / University Press / Plimpton Press, 1907-1930. http://curtis.library.northwestern.edu/index.html.

Curtis, Edward S. “Photography." Western Trail, January 1900: 186-188.

Curtis, Edward S. Prayer to the Great Mystery: The Uncollected Writings and Photography of Edward S. Curtis. Edited by Gerald Hausman and Bob Kapoun. St. Martins Press, 1995.

Curtis, Edward S., and Christopher Cardozo. Native Nations: First North Americans as Seen by Edward Curtis. New York: Bulfinch, 1993.

Danzing, Rachel, and Ann Baldwin. "Pilot Project to Treat Photogravures on Gampi Paper from Edward Curtis' 'The North American Indian.'” Abstract. In "Treatment 2017: Innovation in Conservation and Collection Care," Abstract Book, 45 (2017): 57-58.

Davis, Barbara. Edward S. Curtis: The Life and Times of a Shadow Catcher. San Francisco: Chronicle Books, 1985.

Day, Sara, ed. Heart of the Circle: Photographs of Native American Women. San Francisco: Pomegranate Artbooks, 1997.

Dewall, Beth Barclay. "Edward Sheriff Curtis: A New Perspective on The North American Indian." History of Photography 6, no. 3 (1982): 223-239.

Di Bello, Patrizio, Colette Wilson and Shamoon Zamir, eds. The Photobook: From Talbot to Ruscha And Beyond. London: I. B. Tauris, 2012.

Dippie, Brian W. Review of The Vanishing Race and Other Illusions: Photographs of Indians by Edward S. Curtis, by Christopher M. Lyman. Western Historical Quarterly 14, no.3 (July 1983): 349-350.

Egan, Shannon. "An American Art: Edward S. Curtis and The North American Indian, 1907-1930." PhD diss., Johns Hopkins University, 2006. ProQuest. 3240701.

Egan, Shannon. "'Yet in a Primitive Condition': Edward S. Curtis's North American Indian." American Art 20, no. 3 (2006): 58-83.

Egan, Timothy. Short Nights of the Shadow Catcher: The Epic Life and Immortal Photographs of Edward Curtis. New York: Houghton Mifflin Harcourt, 2012.

Gidley, Mick. Edward S. Curtis and the North American Indian Project in the Field. University of Nebraska Press, 2003.

Gidley, Mick. Edward S. Curtis and the North American Indian, Incorporated. Cambridge: Cambridge University Press, 1998.

Gidley, Mick. "Edward S. Curtis Goes to the Mountain." The Pacific Northwest Quarterly 75, no. 4 (1984): 164-170. 
Gidley, Mick. "Edward S. Curtis' Indian Photographs: A National Enterprise." In Representing Others: White Views of Indigenous Peoples, edited by Mick Gidley, 103-119. Reprint, Exeter: University of Exeter Press, 1994.

Gidley, Mick. "Edward S. Curtis speaks...." History of Photography 2, no. 4 (1978): 347-354

Gidley, Mick. "Pictorialist Elements in Edward S. Curtis's Photographic Representation of American Indians." In "Ethnicity and Representation in American Literature." Special issue. Yearbook of English Studies 24 (1994): 180-92.

Graybill, Florence Curtis, and Victor Boesen. Edward Sheriff Curtis: Visions of a Vanishing Race. New York: American Legacy Press, 1976.

Grundberg, Andy. "More than Meets the Eye." Review of The Vanishing Race and Other Illusions: Photographs of Indians by Edward S. Curtis. New York Times, September 5, 1982.

Gulbrandsen, Don. Edward Sheriff Curtis: Visions of the First Americans. New Jersey: Chartwell Books, 2006.

Hartmann, Sadakichi. Valiant Knights of Daguerre: Selected Essays on Photography and Profiles of Photographic Pioneers. Berkeley: University of California Press, 1978.

Holm, Bill and George Irving Quimby. Edward S. Curtis in the Land of the War Canoes: A Pioneer Cinematographer in the Pacific Northwest. Seattle: University of Washington Press, 1980.

Holm, Bill. Review of The Vanishing Race and Other Illusions, by Christopher M. Lyman. American Indian Art Magazine 8, no. 3 (1983): 68-73.

John Andrew \& Son Sample Book of Photogravures. David A. Hanson Collection of the History of Photomechanical Reproduction. Sterling and Francine Clark Art Institute, Williamstown, MA. http://maca.contentdm.oclc.org/cdm/ref/collection/p1325coll1/id/3743.

Lawlor, Laurie. Shadow Catcher: The Life and Work of Edward S. Curtis. New York: Walker, 1994.

Lee, William Beachum. "The Nature of Reality in Ethnographic Film: A Study Based on the Work of Edward Sheriff Curtis." PhD thesis, University of California, Los Angeles, 1980.

Lowry, Shannon. Natives of the Far North: Alaska's Vanishing Culture in the Eye of Edward S. Curtis. Mechanicsburg, PA: Stackpole Books, 1994.

Lyman, Christopher M. The Vanishing Race and Other Illusions: Photographs of Indians by Edward S. Curtis. New York: Pantheon, 1982.

Makepeace, Anne. Edward S. Curtis: Coming to Light. National Geographic, 2001.

Meissner, Dennis. "First Things First: Reengineering Finding Aids for Implementation of EAD." The American Archivist 60, no. 4 (Fall, 1997): 372-378. 
Mifflin, Jeffrey. Review of Short Nights of the Shadow Catcher: The Epic Life and Immortal Photographs of Edward S. Curtis, by Timothy Egan. American Indian Quarterly 38, no. 1 (2014): 116-119.

Peabody Essex Museum. Edward Curtis: The Master Prints. Arena Editions, 2001.

Ritzenthaler, Mary Lynn, and Diane Vogt-O'Connor. Photographs: Archival Care and Management. Chicago: Society of American Archivists, 2006.

Scandiffio, Theresa. "Choreographing the Past: Edward S. Curtis' 'In the Land of the Head-Hunters.'” Master's thesis, York University (Canada), 2001. ProQuest. MQ71621.

Scherer, Joanna C. Review of Short Nights of the Shadow Catcher: The Epic Life and Immortal Photographs of Edward S. Curtis, by Timothy Egan. Visual Anthropology 28, no. 2 (2015): 183185.

Scherer, Joanna Cohan. "You Can't Believe Your Eyes: Inaccuracies in Photographs of North American Indians." Studies in the Anthropology of Visual Communication 2, no. 2 (1975): 67-79. Reprinted in Exposure Winter 1978.

Skeens, Heather. "Pictures, not merely photographs: Authenticity, performance and the Hopi in Edward S. Curtis's The North American Indian." Master's thesis, lowa State University, 2016.

Solomon, Mary and Dan Solomon. Sites and Structures: The Architectural Photographs of Edward S. Curtis. San Francisco: Chronicle Books, 2000.

Sutnik, Maia-Mari. Edward S. Curtis: Photographs of Indians. Art Gallery of Ontario, 1988.

Touchie, Rodger D. Edward S. Curtis: Above the Medicine Line; Portraits of Aboriginal Life in the Canadian West. Vancouver, BC: Heritage, 2010.

Upham, Steadman, and Nat Zappia. The Many Faces of Edward Sheriff Curtis: Portraits and Stories from Native North America. Seattle: University of Washington Press, 2006.

Youngblood, Wayne L. Native Land Native People: From the Edward S. Curtis Collection. Chartwell Books, 2008.

Zamir, Shamoon. The Gift of Face: Portraiture and Time in Edward S. Curtis's The North American Indian. Chapel Hill, NC: University of North Carolina Press, 2014.

Zamir, Shamoon. "Native Agency and the Making of The North American Indian: Alexander B. Upshaw and Edward S. Curtis." American Indian Quarterly 31, no. 4 (2007): 613-53. 